\title{
Estudios en las Apocynaceae neotropicales XXXIX: revisión de las Apocynoideae y Rauvolfioideae de Honduras
}

\author{
por \\ J. Francisco Morales \\ Instituto Nacional de Biodiversidad (INBio). Apto. 23-3100, Santo Domingo de Heredia, Costa Rica.
}

\begin{abstract}
Resumen
Morales, J.F. 2009. Estudios en las Apocynaceae neotropicales XXXIX: revisión de las Apocynoideae y Rauvolfioideae de Honduras. Anales Jard. Bot. Mad. 66(2): 217-262.

Se presenta un tratamiento de las subfamilias Apocynoideae y Rauvolfioideae (Apocynaceae) en la República de Honduras, Centroamérica. Un total de 55 especies distribuidas en 30 géneros (Allamanda, Allomarkgrafia, Anechites, Aspidosperma, Beaumontia, Carissa, Cascabela, Catharanthus, Echites, Fernaldia, Forsteronia, Lacmellea, Macropharynx, Malouetia, Mandevilla, Mesechites, Nerium, Odontadenia, Pentalinon, Plumeria, Prestonia, Rauvolfia, Rhabdadenia, Stemmadenia, Tabernaemontana, Thenardia, Thevetia, Tintinnabularia, Tonduzia, Vallesia) son tratadas, siendo Echites, Mandevilla, Prestonia, Tabernaemontana y Thevetia los más representativos. Se brindan descripciones, claves, datos de ecología, distribución, fenología, nombres comunes y especímenes examinados, así como fotografías para la mayoría de ellas. Se reporta por primera vez la presencia de Allomarkgrafia plumeriiflora, Anechites nerium, Macropharynx renteriae, Stemmadenia eubracteata y Thenardia chiapensis en Honduras.
\end{abstract}

Palabras clave: Apocynaceae, Apocynoideae, Rauvolfioideae, Mesoamérica, Honduras.

\section{Introducción}

La familia Apocynaceae (incluyendo las Asclepiadaceae), abarca ca. 355 géneros y más de 3700 especies (Endress \& Bruyns, 2000), divididas en cinco subfamilias. En este contexto, las Apocynaceae tal y como habían sido conocidas tradicionalmente (“Apocynaceae s. str.") quedaron restringidas a las subfamilias Apocynoideae y Rauvolfioideae. En la actualidad existen tratamientos taxonómicos de las Apocynaceae s. str. para la mayoría de los países de Centroamérica, ya sean recientes como el de Costa

\begin{abstract}
Morales, J.F. 2009. Study in Neotropical Apocynaceae XXXIX: review of Apocynoideae and Rauvolfioideae from Honduras. Anales Jard. Bot. Madrid. 66(2): 217-262 (in Spanish).

A treatment of the subfamilies Apocynoideae and Rauvolfioideae (Apocynaceae) in Honduras, is presented. A total of 55 species in 30 genera (Allamanda, Allomarkgrafia, Anechites, Aspidosperma, Beaumontia, Carissa, Cascabela, Catharanthus, Echites, Fernaldia, Forsteronia, Lacmellea, Macropharynx, Malouetia, Mandevilla, Mesechites, Nerium, Odontadenia, Pentalinon, Plumeria, Prestonia, Rauvolfia, Rhabdadenia, Stemmadenia, Tabernaemontana, Thenardia, Thevetia, Tintinnabularia, Tonduzia, Vallesia) are treated. Echites, Mandevilla, Prestonia, and Tabernaemontana are the most representative genera. Descriptions, keys, data on ecology, distribution, phenology, common names as well as lists of specimens examined are provided. Photographs are provided for the majority of species. The presence in Honduras of Allomarkgrafia plumeriiflora, Anechites nerium, Macropharynx renteriae, Stemmadenia eubracteata and Thenardia chiapensis is reported here for the first time.
\end{abstract}

Keywords: Apocynaceae, Apocynoideae, Rauvolfioideae, Mesoamerica, Honduras.

Rica (Morales, 2005a), Nicaragua (Gentry, 2001) y El Salvador (Morales, 2006a) o relativamente más antiguos, como son los casos de Panamá (Nowicke, 1970) y Guatemala (Standley \& Williams, 1969). Sin embargo, no existen tratamientos para Belice y Honduras.

La República de Honduras posee una extensión aproximada de $112000 \mathrm{~km}^{2}$, convirtiéndose en el segundo país más grande de Centroamérica, después de Nicaragua. Limita al N y E con el mar Caribe, al $\mathrm{S}$ con Nicaragua, al SE con el océano Pacífico y El Salvador, y Guatemala al W (Fig. 1). Con un total de 


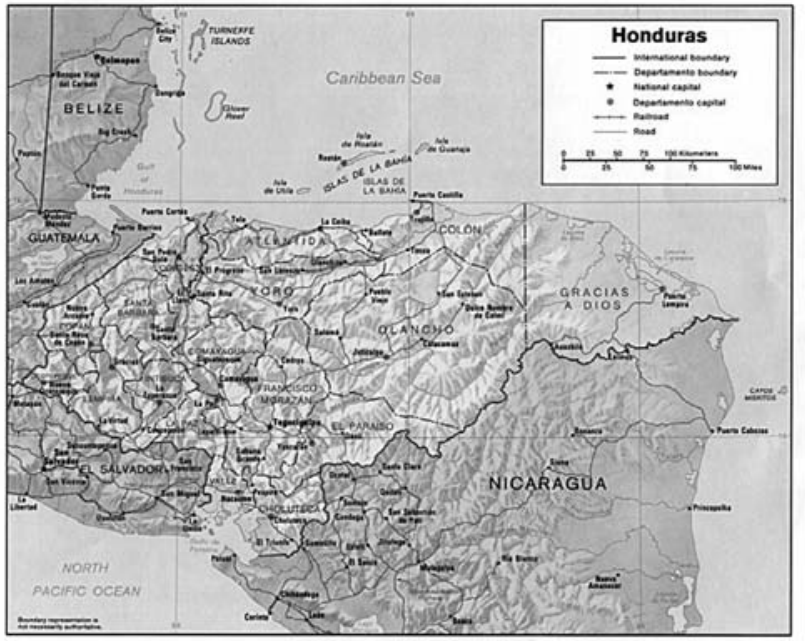

Fig. 1. Mapa de la República de Honduras (cortesía de la biblioteca de la Universidad de Texas, Austin, Estados Unidos, http://www.lib.utexas.edu/maps/americas/honduras.jpg).

18 departamentos, la geografía del país es notablemente diversa, por lo que una serie de ecosistemas pueden ser encontrados en elevaciones que abarcan desde el nivel del mar hasta altitudes ligeramente superiores a los $2800 \mathrm{~m}$ (Nelson, 2008; Pineda, 1997). Al igual que en el resto de los países centroamericanos, el clima es tropical, con una estación lluviosa que se extiende de mayo a noviembre, y la seca, de diciembre a abril, con promedios de temperaturas de 15 a $20^{\circ} \mathrm{C}$ para las regiones centrales y de 20 a $40^{\circ} \mathrm{C}$ para los litorales. En la actualidad las selvas remanentes presentes en el país cubren cerca de una tercera parte de su territorio.

Honduras carece de un tratamiento integral de su Flora y prácticamente las únicas fuentes disponibles la constituyen un listado preliminar (Molina, 1975) y subsecuentes adiciones publicadas a través de los años (e.g., Molina, 1977, 1984; Nelson, 1976, 1977, 1979). Recientemente, Nelson (2008) publicó un Catálogo de las Plantas Vasculares de Honduras, el cual compila el total de especies de flora registradas para el país hasta esa fecha. En el caso de las Apocynaceae s. str., el único tratamiento de utilidad parcial es el de Woodson (1938a), el cual no es exclusivo para Honduras y trata todas las especies y géneros presentes desde el $\mathrm{S}$ de Estados Unidos a Panamá, sin localidades precisas para cada país o listados de especímenes examinados. En este tratamiento se reportaron un total de 13 géneros y 20 especies, en contraposición con el listado de Molina (1975), el cual reporta 27 géneros y 54 especies, de los cuales 10 géneros y 19 especies se conocían sólo de cultivo. Sin embargo, ambos se encuentran bastante desactualizados por los numerosos cambios taxonómicos que han sido propuestos en los últimos años.
Se presenta un tratamiento de las subfamilias Apocynoideae y Rauvolfioideae para la República de Honduras. Para tal fin, se revisaron especímenes de los principales herbarios de los Estados Unidos (e.g., DUKE, F, MO, NY, US), Europa (e.g., BM, BR, CGE, G, K, MA, P, U, W, WAG, WU) y Mesoamérica (BIGU, CR, EAP, INB, LAGU, TEFH, UVAL). Este tratamiento sigue el mismo formato y metodología citada por Morales (2005a) para las Apocynaceae de Costa Rica, por lo que su explicación detallada no se repetirá aquí. Algunas descripciones fueron tomadas de diversas monografías en desarrollo (e.g., Mandevilla, Prestonia), por lo que los datos de distribución o morfología pueden diferir de otros anteriormente publicados (e.g., Woodson, 1933, 1936). Para cada taxón se brinda la sinonimia más relevante, sobre todo cuando se trate de cambios propuestos en forma reciente que no fueron abarcados en monografías previas o de complejos de especies que se han visto envueltos en cierta polémica taxonómica a través del tiempo (e.g., Prestonia, Stemmadenia). Con excepción de Thenardia y Tintinnabularia, se incluyen fotografías para todos los géneros tomadas por el autor, excepto en aquellos casos donde se indique lo contrario (véanse los respectivos créditos en los agradecimientos).

En general, los datos de fenología, nombres comunes y usos fueron tomados directamente de las etiquetas de herbario, mencionándose para los dos últimos de ellos el Departamento. Sin embargo, varios nombres vernáculos fueron tomados de los trabajos de Nelson $(1986,2008)$, por lo que en dichos casos se cita la referencia directamente. Nombres vernáculos y usos adicionales registrados de otros países circundantes pueden ser consultados en Morales (2005a, 2006a). Más de 1500 especímenes de herbario fueron examinados, incluyendo la mayoría de colecciones tipo. Se mencionan ejemplares representativos para cada especie y la lista total se encuentra en el Apéndice 1. A través del tratamiento, las siglas de los herbarios citados siguen a Holmgren \& al. (1990).

Existe una serie de estructuras morfológicas necesarias de identificar y reconocer para poder usar apropiadamente las claves y entender los límites genéricos de algunos grupos. Una detallada explicación de estos tópicos ha sido expuesta anteriormente por Ezcurra (1981), Morales (2005a, 2006a) y Simões \& Kinoshita (2002) y, por lo tanto, no se repite aquí. Sólo se ilustrarán las partes morfológicas más importantes de los géneros aquí tratados con el objetivo de facilitar el uso de las claves. Por lo tanto, la posición y tipos de coléteres son ilustrados en las Figs. 2, 3 y 4, mientras que algunos componentes estructurales particulares de la corola y del ovario son ilustrados en las Figs. 5, 6 y 7. Las 

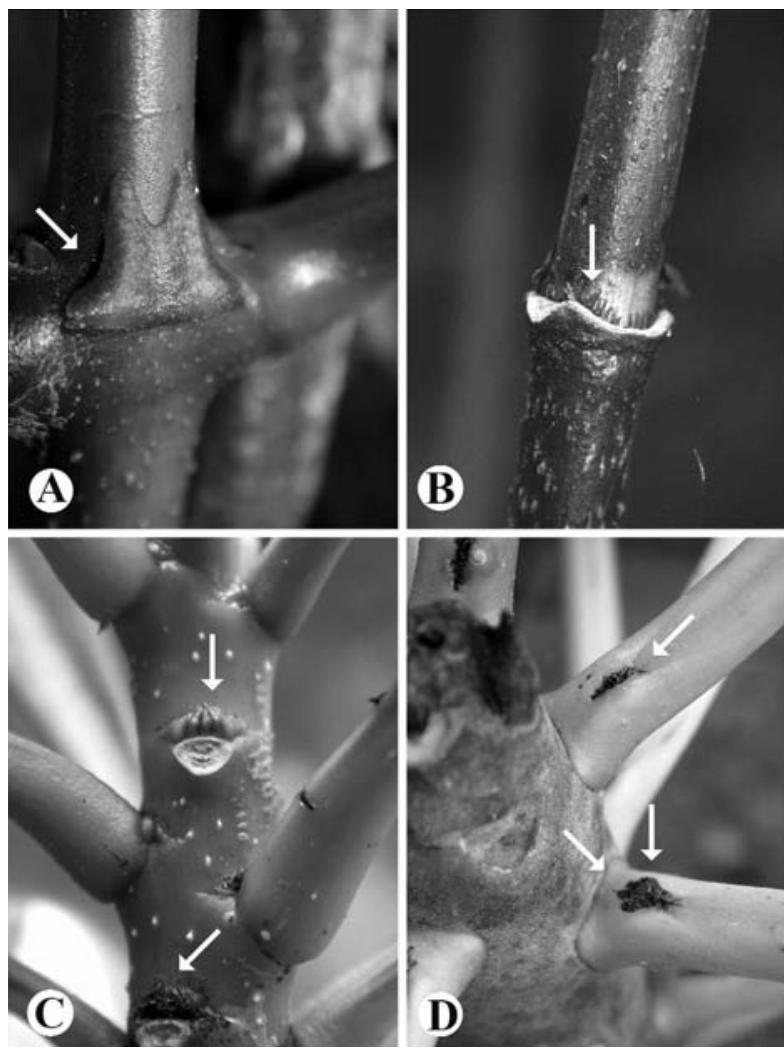

Fig. 2. Posición de coléteres en tallos y pecíolos. A, interpeciolares (Odontadenia verrucosa; B, O. puncticulosa); C, intrapeciolares (Cascabela ovata); D, en el peciolo (Plumeria rubra).
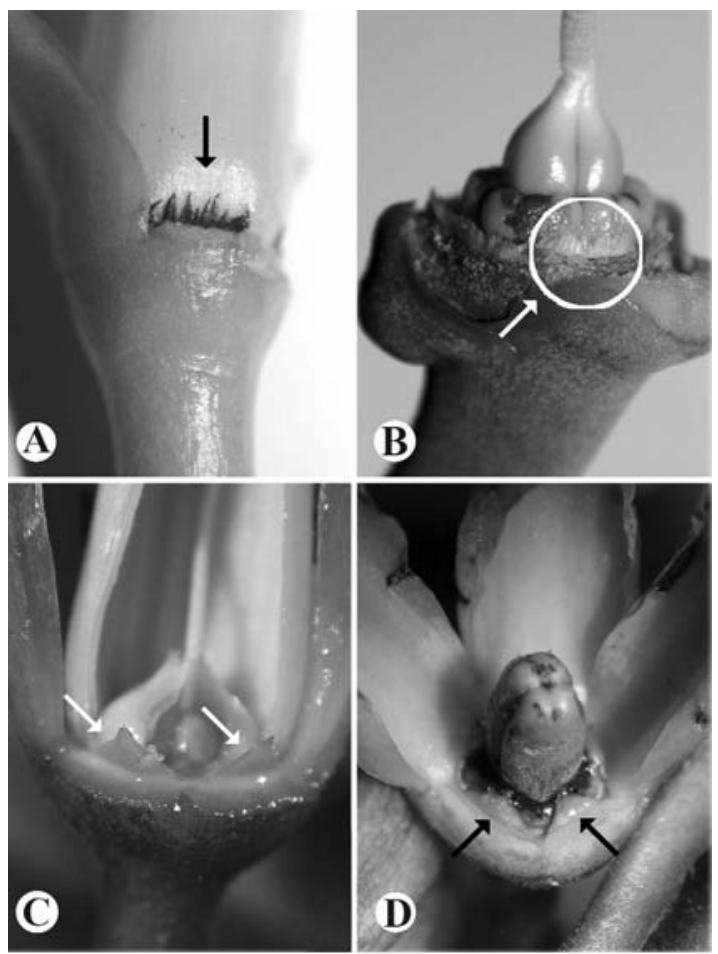

Fig. 4. Coléteres de los sépalos. A, Cascabela ovata; B, Stemmadenia donnell-smithii; C,D, Prestonia portobellensis.
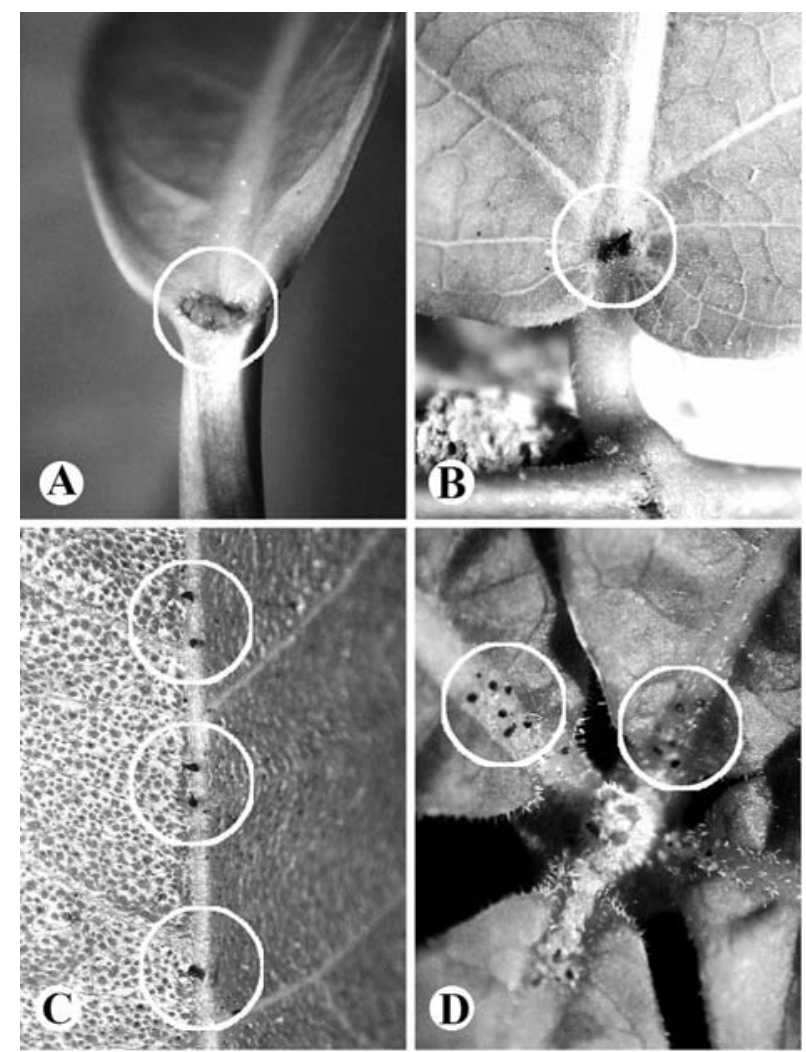

Fig. 3. Coléteres en láminas foliares agrupados en la base del nervio central (A, Allomarkgrafia plumeriiflora; B, Forsteronia spicata); C, distribuidos a lo largo del nervio central (Mandevilla hirsuta); D, dispersos en la base del nervio central (Rauvolfia tetraphylla).

claves de los géneros y especies están diseñadas para ser usadas específicamente en Honduras.

Algunos géneros y especies son conocidos en Honduras sólo por cultivo y en localidades muy restringidas, tales como el Jardín Botánico Lancetilla en el Departamento de Atlántida o en la Universidad El Zamorano, en el Departamento de Francisco Morazán. Por tal razón, no son incluidas en este tratamiento. Entre ellas tenemos Trachelospermum jasminoides (Lindl.) Lem. (Standley 29525, EAP), cultivada anteriormente en el Zamorano, y Strophanthus caudatus (L.) Kurz, conocida por un único espécimen de la estación Lancetilla, Atlántida (Molina 10351, EAP). Al menos en el caso de la primera especie, no se localizaron plantas cultivadas en el Zamorano en el 2005.

\section{Tratamiento taxonómico}

Apocynaceae Juss. Gen. Pl. 143. 1789

Árboles, arbustos, hierbas o lianas; tallos jóvenes algunas veces alados o acostillados; el tronco inerme o 

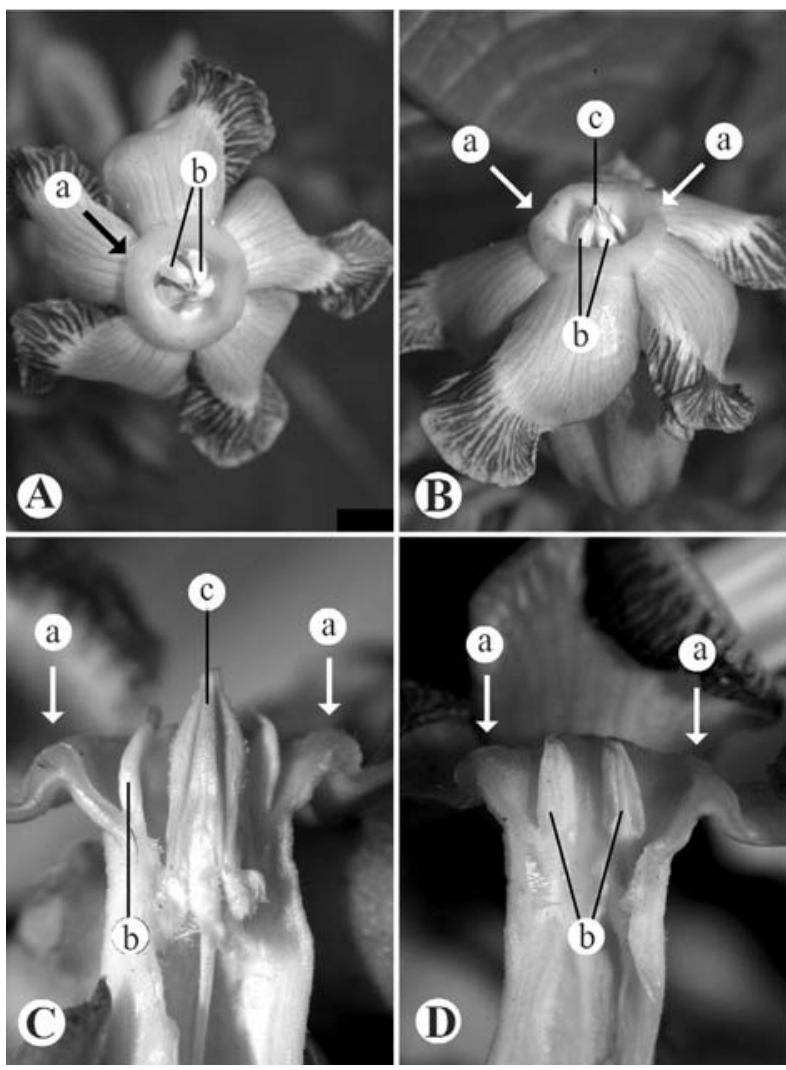

Fig. 5. Componentes de la corola. A-D, Prestonia portobellensis. a, corona anular; b, lóbulos coronales libres; c, anteras.

armado con aguijones o espinas, con secreción al cortarse (a veces casi no evidente), blanca, crema, rojiza, morada o acuosa y transparente, en algunos géneros comestible, coléteres inter e intrapeciolares conspicuos o inconspicuos. Hojas simples, opuestas, verticiladas o alternas, algunas veces espiraladas, enteras, algunas veces con coléteres en el nervio central, agrupados en su base o distribuidos a lo largo, o dispuestos sobre el pecíolo, domacios algunas veces presentes, estípulas raramente presentes. Inflorescencias racemosas, paniculadas o cimosas, algunas veces reducidas a flores solitarias, extraaxilares a terminales o subterminales, brácteas escamiformes a foliáceas, bractéolas algunas veces presentes, flores bisexuales, actinomorfas, con estivación sinistrorsa, dextrorsa o valvada, 5-meras, aunque a veces con 3 ó 6 sépalos, raramente el cáliz bilabiado, de longitudes similares o desiguales, con coléteres en la base de la cara adaxial o eglandulares; corola gamopétala, hipocraterimorfa, infundibuliforme o urceolada, estructuras coronales accesorias algunas veces presentes, constituidas por coronas anulares o una corona epiestaminal conformada por cinco lóbulos coronales libres (corona coralina), estos algunas veces reducidos a crestas callosas,

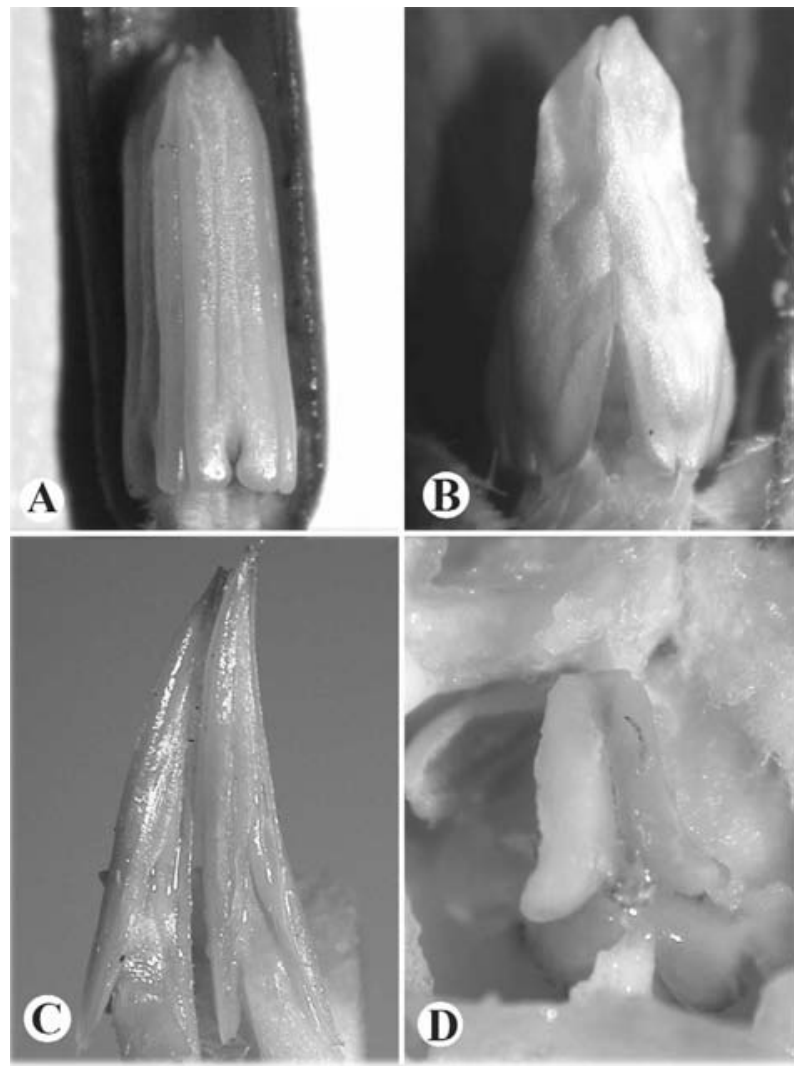

Fig. 6. Anteras. A, Mesechites trifidus; B, Mandevilla hirsuta; C, Stemmadenia donnell-smithii; D, Thevetia ahouai.

limbo con cinco lóbulos o pétalos; estambres epitpétalos, incluidos o exsertos, filamentos cortos e inconspicuos a evidentes y conspicuos, algunas veces fusionados entre sí y adnatos al ápice del estilo, formando un tubo alrededor del gineceo (ginostegio), el ginostegio con apéndices de formas diversas (corona), entera o con 5 lóbulos, anteras biloculares, introrsas,

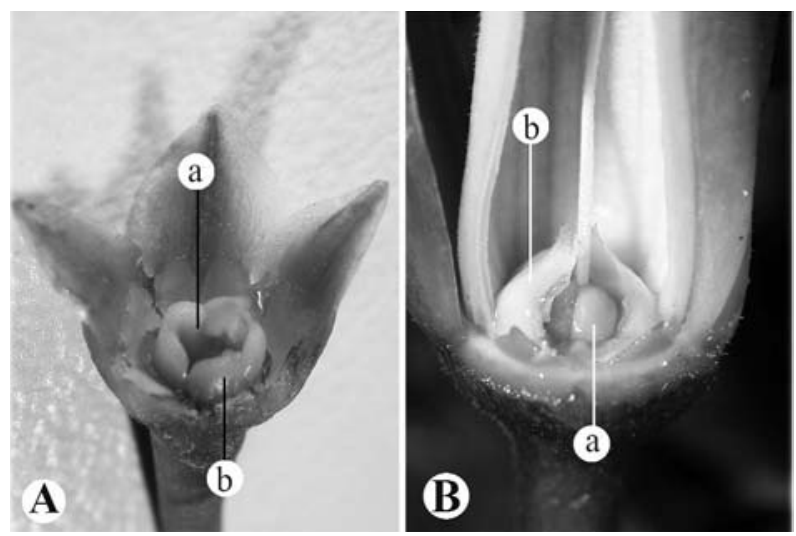

Fig. 7. Nectarios y ovario en Apocynaceae.A, Mesechites trifidus; B, Prestonia portobellensis. a, ovario; b, nectario. 
conniventes y aglutinadas a la cabeza estigmática o las anteras libres y no aglutinadas, la base usualmente estéril, algunas veces auriculadas o con dos alas marginalmente, polen granular o el polen en cada lóculo aglutinado en una masa cerosa (el polinio) y cada uno en el extremo de dos brazos, éstos conectados a un corpúsculo central; gineceo bicarpelar unido apicalmente por el estilo, ovario supero o medioínfero, bilocular, con placentación axilar o parietal, usualmente con numerosos óvulos, óvulos 1 o varios por lóculo, estilo simple, cabeza estigmática variable en forma. Frutos apocárpicos o sincárpicos, foliculares, capsulares, abayados o drupáceos, a veces con sólo un carpelo desarrollado por aborto; semillas 1 a muchas, desnudas, aladas, ariladas o secas, en frutos foliculares usualmente comosas en el ápice micropilar o calazal.

En Honduras podemos encontrar 30 géneros y 55 especies.

1. Hojas alternas o subalternas, algunas veces agrupadas al final de las ramas o nudos y pareciendo subopuestas, pero nunca consistentemente opuestas ................................. 2

1. Hojas estrictamente opuestas o verticiladas, nunca alternas

2. Sépalos con numerosos coléteres en la base de la cara adaxial; corola infundibuliforme o hipocraterimorfa; frutos drupáceos o abayados, rojos, rojizo-morados, morados o negros al madurar

2. Sépalos sin coléteres en la base de la cara adaxial; corola estrictamente hipocraterimorfa; frutos foliculares o, si drupáceos (Vallesia), entonces blanco-verdosos al madurar ...... 4

3. Corola hipocraterimorfa, crema a verde-crema; frutos abayados, rojos al madurar....

27. Thevetia

3. Corola infundibuliforme, amarilla; frutos drupáceos, morados a morado-rojizos al madurar .....

7. Cascabela

4. Frutos drupáceos, carnosos al madurar; semillas sin alas marginales; hojas por lo común dísticas ......... 30. Vallesia

4. Frutos foliculares, secos, leñosos o firmemente membranáceos al madurar; semillas usualmente con alas marginales; hojas nunca dísticas

5. Lóbulos de la corola usualmente más de $2 \mathrm{~cm}$ de largo; folículos falcados y cilíndricos en corte transversal, no leñosos.

20. Plumeria

5. Lóbulos de la corola menos de 1,5 cm de largo; folículos aplanados lateralmente, leñosos .......... 4. Aspidosperma

6. Hojas mayormente verticiladas, raramente algún nudo con hojas opuestas ............................................................ 7

6. Hojas mayormente opuestas, rara vez algún nudo con hojas verticiladas

10

7. Tubo de la corola con cinco lóbulos coronales, erectos y petaloides, en forma opuesta a cada antera; semillas con coma apical; plantas cultivadas.

17. Nerium

7. Tubo de la corola sin lóbulos coronales o si presentes (Allamanda) entonces no erectos y petaloides; semillas aladas 0 ciliadas marginalmente, sin coma apical ........................ 8

8. Corola infundibuliforme, amarilla, morado o lila; frutos capsulares, espinosos en la superficie exterior; semillas con alas marginales; lóbulos coronales presentes; plantas cultivadas o silvestres

1. Allamanda
8. Corola hipocraterimorfa a urceolada, blanca o crema; frutos drupáceos o foliculares, pero entonces lisos en la superficie exterior, sin espinas; lóbulos coronales ausentes; plantas silvestres

9. Frutos folículos secos; semillas con los márgenes ciliados; pecíolos sin coléteres en la superficie adaxial; lóbulos de la corola más de $2 \mathrm{~mm}$ de largo; hojas siempre isofilas

29. Tonduzia

9. Frutos drupas, carnosas; semillas no ciliadas; pecíolos con coléteres en la superficie adaxial; lóbulos de la corola ca. 1 $\mathrm{mm}$ de largo; hojas isófilas o anisófilas ........ 22. Rauvolfia

10. Corola más de $10 \mathrm{~cm}$ de largo; filamentos largos y conspicuos, evidentes, de varios cm de longitud; plantas cultivadas

5. Beaumontia

10. Corola menos de $8 \mathrm{~cm}$ de largo; filamentos inconspicuos, menos de $2 \mathrm{~mm}$ de longitud ...................................... 11

11. Tallos con espinas bifurcadas en los nudos; plantas culti-

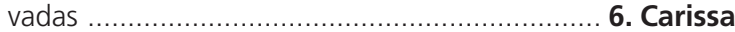

11. Tallos siempre sin espinas ........................................ 12

12. Árboles o arbustos erectos de varios metros de altura (hasta 15 m o más), usualmente con un tronco principal o varios tallos múltiples definidos, nunca escandentes ............... 13

12. Lianas, arbustos escandentes o hierbas erectas, algunas veces arbustivas (Catharanthus), pero entonces menos de 1,5 $\mathrm{m}$ de altura y nunca desarrollando un tallo leñoso principal y erecto de varios metros de longitud ......................... 16

13. Anteras truncadas, cordadas o redondeadas en la base, raramente sagitadas; semillas no ariladas......................... 14

13. Anteras sagitadas en la base, con las bases estériles acuminadas o agudas; frutos folículos con semillas ariladas .... 15

14. Frutos bayas indeshicentes, amarillos o anaranjados al madurar; cabeza estigmática fusiforme, corta y apiculada en forma abrupta; láminas foliares siempre sin domacios; tronco principal algunas veces con aguijones .... 12. Lacmellea

14. Frutos folículos dehiscentes, verdosos o crema-verdosos al madurar; cabeza estigmática globosa, con un ápice alargado y cónico; láminas foliares con domacios en el envés a lo largo del nervio central; tronco principal siempre sin aguijones......

14. Malouetia

15. Tubo de la corola con cinco proyecciones o crestas bajo las anteras

24. Stemmadenia

15. Tubo de la corola sin alas bajo las anteras

25. Tabernaemontana

16. Láminas foliares con coléteres diminutos en la superficie abaxial del nervio central, distribuidos a lo largo de su entera extensión o agrupados en la base ............................. 17

16. Láminas foliares sin coléteres en el nervio central .......... 21

17. Anteras exertas, con al menos $1 / 3$ de su longitud exserto; tubo de la corola inferior a 3,5 mm de largo; láminas foliares algunas veces con domacios

11. Forsteronia

17. Anteras siempre incluidas; tubo de la corola superior a (4)10 $\mathrm{mm}$ de longitud; láminas foliares usualmente sin domacios, si los domacios presentes (Tintinnabularia), entonces las anteras con conspicuos apéndices apicales ..................... 18

18. Inflorescencias racemosas ................... 15. Mandevilla

18. Inflorescencias cimosas ........................................... 19

19. Corola hipocraterimorfa ....................... 16. Mesechites

19. Corola infundibuliforme ...................................... 20

20. Anteras sin filamentos apicales; láminas foliares sin domacios a lo largo del nervio central abaxialmente; venas terciarias más o menos consistentemente perpendiculares al nervio central

2. Allomarkgrafia

20. Anteras con filamentos apicales; láminas foliares usualmente con domacios a lo largo del nervio central abaxialmente; venas terciarias no consistentemente perpendiculares al nervio central

28 . Tintinnabularia 
21. Lóbulos de la corola con estivación sinistrorsa; anteras libres de la cabeza estigmática; semillas sin coma; sépalos de forma usual sin coléteres en la base de la cara adaxial ....... 22

21. Lóbulos de la corola con estivación dextrorsa o valvar; anteras aglutinadas a la cabeza estigmática; semillas de forma usual con algún tipo de coma presente en uno solo de los extremos; sépalos en forma usual con coléteres en la base de la cara adaxial, de forma más rara sin coléteres (Rhabdadenia)

23

22. Lianas escandentes o trepadoras, nunca rastreras; tallos y láminas foliares con pelos con conspicuas bases multicelulares; flores dispuestas de forma laxa en un racimo, con un largo pedúnculo

3. Anechites

22. Arbustos o hierbas arbustivas erectas; tallos y láminas de forma usual glabros o glabrescentes, con pubescencia diversa, pero los pelos sin bases multicelulares; flores solitarias o en fascículos de 1 a 4, aglomeradas, con un pedúnculo corto e inconspicuo

8. Catharanthus

23. Corola con una corona anular alrededor de la fauce, de forma usual con cinco lóbulos coronales libres en la superficie interna (corona epiestaminal), algunas veces estos ausentes y reducidos a callos o crestas callosas longitudinales

21. Prestonia

23. Corola sin una corona anular alrededor de la fauce; lóbulos coronales ausentes

.. 24

24. Cáliz sin coléteres; inflorescencias de manera usual con 1 a 2(3) flores; (plantas de manglares o áreas anegadas asociadas)

23. Rhabdadenia

24. Cáliz con coléteres; inflorescencias de manera usual con muchas flores ................................................. 25

25. Anteras exsertas (al menos un tercio de su longitud total); tubo de la corola inconspicuo, raramente hasta $4 \mathrm{~mm}$ de largo; corola rotada .................................................... 26

25. Anteras siempre incluidas; tubo de la corola evidente, de manera usual más de $5 \mathrm{~mm}$ de largo; corola no rotada . 27

26. Inflorescencias panículas tirsoides terminales o subterminales; sépalos con varios coléteres en la base de la cara adaxial; domacios ausentes o presentes; folículos libres

11. Forsteronia

26. Inflorescencias cimas subumbeliformes, axilares; sépalos con un coléter solitario epicéntrico en la base de la cara adaxial; domacios siempre ausentes; folículos fusionados longitudinalmente

26. Thenardia

27. Lóbulos de la corola densa a moderadamente villosas en la superficie adaxial, los pelos blancos, conspicuos y largos, de manera usual de varios $\mathrm{mm}$ de longitud; inflorescencias estrictamente racemosas

10. Fernaldia

27. Lóbulos de la corola glabros, glabrescentes a diminutamente puberulentos en la superficie adaxial, los pelos diminutos e inconspicuos, hasta $1 \mathrm{~mm}$ de largo, no blancos; inflorescencias de varios tipos, a veces racemosas, pero los lóbulos sin pelos largos y conspicuos ....................................... 28

28. Pedicelos con una a varias bractéolas inmediatamente debajo del cáliz o dispuestas de manera irregular a lo largo de su longitud, las bractéolas dispuestas debajo del cáliz casi tan largas como los sépalos

13. Macropharynx

28. Pedicelos sin bractéolas, únicamente brácteas florales presentes en la base del pedicelo ..................................... 29

29. Anteras con apéndices apicales filiformes, usualmente de varios $\mathrm{mm}$ de longitud y entrelazados entre sí

19. Pentalinon

29. Anteras con apéndices apicales inconspicuos, triangulares, pero nunca filiformes o de varios $\mathrm{mm}$ de longitud ......... 30

30. Tallos con secreción lechosa; sépalos con varios coléteres en la base de la cara adaxial; cabeza estigmática sin un anillo basal; semillas truncadas

18. Odontadenia
30. Tallos con secreción acuosa; sépalos con un coléter solitario epicéntrico en la base de la cara adaxial; cabeza estigmática con un anillo basal; semillas rostradas

9. Echites

\section{Allamanda L., Mant. Pl. 2: 146, 214 (576). 1771}

Arbustos erectos o escandentes o arbolitos, tallos con secreción lechosa, glabros a puberulentos, sin espinas o aguijones, coléteres intrapeciolares diminutos. Hojas opuestas o en verticilos de 3 ó 4, raramente subopuestas, eglandulares, la lámina glabra o pubescente, pecioladas a subsésiles. Inflorescencias cimosas, axilares, subterminales o terminales, con pocas flores; brácteas foliáceas a escariosas; cáliz con 5 sépalos, usualmente similares, foliáceos, algunas veces con coléteres o los coléteres ausentes; corola infundibuliforme, sin corona anular o lóbulos coronales libres, amarilla a púrpura, púrpura-café o lila, limbo con 5 lóbulos, con estivación sinistrorsa; estambres totalmente incluidos, anteras no conniventes ni aglutinadas a la cabeza estigmática, cabeza estigmática cilíndrica, bicapitada en el ápice; gineceo bicarpelar, sincárpico, nectario anular, entero a lobulado. Frutos cápsulas sincárpicas, usualmente espinosos, raramente lisos y las espinas ausentes, leñosos; semillas comprimidas, aladas, numerosas, no comosas.

Género con 14 especies principalmente en Brasil, 3 conocidas en Honduras, 2 de ellas solo de cultivo ( $\mathrm{Sa}$ kane \& Sheperd, 1987). Allamanda blanchetii A. DC. se ha cultivado en forma esporádica en San Pedro Sula, Departamento de Cortés (Pérez s.n., EAP) y se separa con facilidad de las otras especies por sus corolas lilas o moradas.

1. Sépalos 13-22 mm de largo, sin coléteres en la base de la cara adaxial; corola con la parte inferior del tubo $3-4,2 \mathrm{~cm}$

1. A. cathartica

1. Sépalos 6-10 mm de largo, con coléteres en la base de la cara adaxial; corola con la parte inferior del tubo 0,9-1,2 cm .......

2. A. schottii

1. Allamanda cathartica L., Mant. Pl. 2: 214-215. 1771

Tipo: Habitat per totam Guianam, juxta fluvios, sin fecha (fl), Herb. Linn. No. 298.1 (neótipo, designado por Leeuwenberg in Jarvis \& al. (1993), S-LINN) (Fig. 8 A,B).

Arbustos escandentes o lianas, las ramitas pubescentes a glabras o glabrescentes. Hojas con láminas 715,4 × 2,5-6,1 cm, obovadas a elípticas, el ápice acuminado, la base obtusa a cuneada, glabras o pubescentes por el envés, pecíolo 2-6 mm de largo. Inflorescencias con 1-6 flores (o más), pedicelos 4-11 mm de largo, brácteas ca. $1 \mathrm{~mm}$ de largo, diminutas, no foliáceas; sépalos 13-22 mm de largo, ovados o elípticos, 
eglandulares sin coléteres; corola amarilla, la parte inferior del tubo 3-4,2 cm de largo, la parte superior 2,5$3,4 \mathrm{~cm}$ de largo, cónica o campanulada, 2,7-3,8 cm de diámetro en la fauce, lóbulos 3,3-5,3 × 3,4-4,8 cm, obovados; anteras ca. 5,5 mm de largo, nectario más corto que el ovario. Cápsula 6-8 cm de diámetro; semillas $18-24 \mathrm{~mm}$ de diámetro.

Distribución. Aunque se piensa originaria de la cuenca baja amazónica, se ha registrado que crece en forma natural al menos en la costa atlántica de Costa Rica, Nicaragua y Honduras. Bosques muy húmedos, pero también cultivada en todo el país en elevaciones de 0-1100 $\mathrm{m}$. Flores y frutos son producidos durante todo el año.

Nombres comunes. "Allamanda" (Olancho); "Bejuco de San José”, "Copa de Oro" (Francisco Morazán); "Amor de estudiante", "San Andrés", "San José" (Nelson, 1986).

Esta especie crece en forma natural en la costa atlántica de Honduras, sobretodo en márgenes de lagunas y sitos anegados. Se puede reconocer con facilidad por el gran tamaño de sus flores amarillas y sus frutos espinosos.

Especímenes representativos examinados. HONDURAS. Atlántida: refugio de Cuero Salado, al W de La Ceiba, 12.VII.1991 (fl), Nelson 11283 (TEFH). Colón: Guaimoreto, 10.VII.1980 (fl), Saunders 462 (MO). Cortés: Cienaguita, al NW de Puerto Cortés, 9.V.1986 (fl), Alvarado 138 (TEFH). Francisco Morazán: cercanías de El Zamorano, 31.VIII.1949 (fl, fr), Standley 23303 (EAP). Gracias a Dios: alrededores del río Plátano, 17-23.V.1973 (fr), Clewell E Cruz 4047 (EAP, MO, TEFH). Olancho: al SE de Catacamas, Escuela Nacional de Agricultura, 1.IV.1987 (fl), Ortega 230 (EAP, MO, TEFH). Yoro: Quebrada Seca, El Progreso, 8.V.1983 (fl), Echeverría 175 (MO).

2. Allamanda schottii Pohl, Pl. Bras. Icon. Descr. 1: 73, pl. 58. 1827

Tipo: Brasil. Rio de Janeiro: San Salvador, río Parayba, sin fecha (fl), A. Schott 5379 (holótipo, W; isótipo, G). (Fig. 8 C,D).

Arbustos erectos a escandentes, tallos glabros o glabrescentes. Hojas con láminas 2,8-5,9 × 1,1-1,8 cm, angostamente obovadas a angostamente elípticas, el ápice agudo a cortamente acuminado, la base cuneada y revoluta, glabras a glabrescentes, pecíolo $1-3 \mathrm{~mm}$ de largo. Inflorescencias hasta con 3-7 flores, pedicelos 3-6 mm de largo, brácteas 4-5 mm de largo, diminutas, no foliáceas; sépalos 6-10 mm de largo, angostamente ovados a angostamente elípticos, con coléteres en la base de la cara adaxial; corola amarilla, la parte inferior del tubo 0,9-1,2 cm de largo, la parte superior 2,2-3 cm, cónica o campanulada, 1,2-1,5 cm de diámetro en la fauce, lóbulos 0,9-1,3 cm de largo, obovados; anteras ca. $4 \mathrm{~mm}$ de largo, nectario más corto que el ovario. Cápsula 2,5-3 cm de diámetro; semillas 21$25 \mathrm{~mm}$ de diámetro.
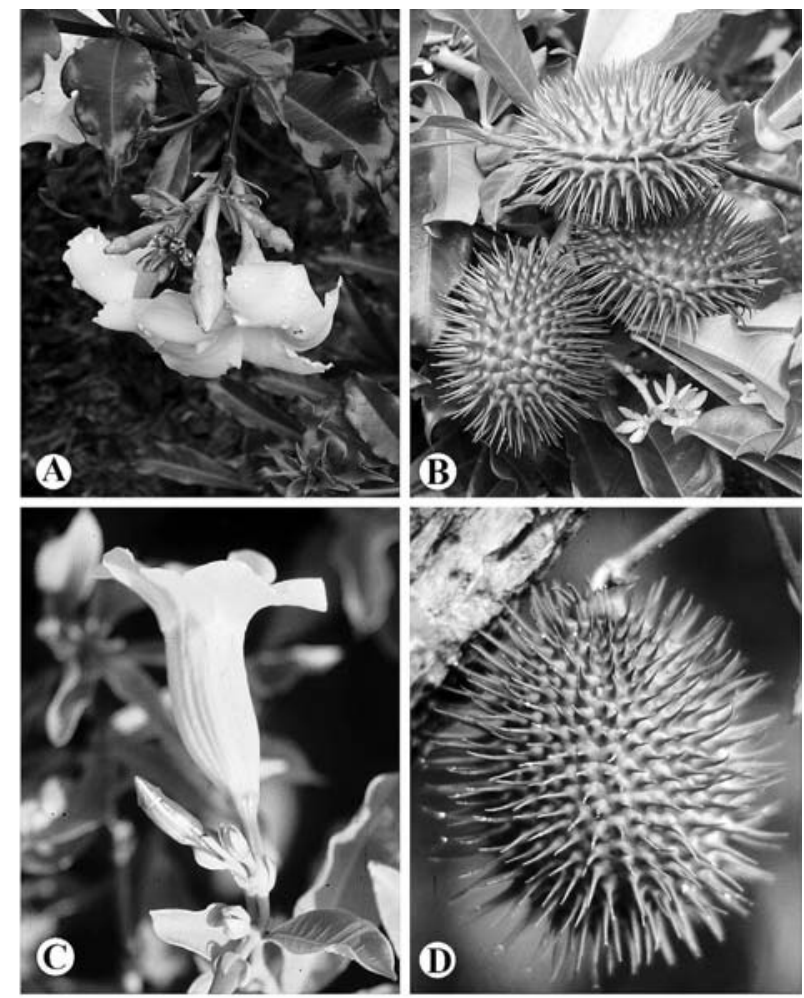

Fig. 8. Allamanda. A,B, Allamanda cathartica. C,D, Allamanda schottii.

Distribución. Originaria de Brasil, se ha cultivado en el trópico con menos intensidad que $A$. cathartica. En Honduras cultivada en forma esporádica en elevaciones de 1400 a $1800 \mathrm{~m}$. Especímenes con flores se registran entre abril y junio.

Allamanda schottii se conoce solo de cultivo en Mesoamérica, donde se ha utilizado en forma esporádica como planta ornamental. Se puede distinguir fácilmente por tener hábito, láminas foliares, flores y frutos mucho más pequeños que $A$. cathartica.

Especimen representativo examinado. HONDURAS. La Paz: Tutule, al NE de La Paz, 13.IV.1997 (fl, fr), Banegas 139 (TEFH).

2. Allomarkgrafia Woodson, Ann. Missouri Bot. Gard. 19(1): 45. 1932

Lianas, tallos con secreción acuosa o acuoso-lechosa, glabros, sin espinas o aguijones, coléteres interpeciolares inconspicuos. Hojas opuestas, con un grupo de coléteres fusiformes en la base del nervio central, láminas glabras, pecioladas. Inflorescencias cimosas, axilares, con pocas a numerosas flores, glabras, brácteas escamiformes; cáliz con 5 sépalos, similares, diminutos, con una línea de coléteres en la base; corola infundibuliforme a subinfundibuliforme, sin corona anular o lóbulos coronales libres, crema, verde crema, 
blanco-rosada o verde-rosada, limbo con 5 lóbulos, la estivación dextrorsa; estambres totalmente incluidos, anteras conniventes y aglutinadas a la cabeza estigmática, cabeza estigmática con cinco costillas o proyecciones basales longitudinales; gineceo bicarpelar, apocárpico, nectarios 5, libres o fusionados en la base y formando un nectario pentalobulado. Frutos folículos apocárpicos, lisos, continuos, membranáceos; semillas numerosas, secas, truncadas y comosas en el ápice micropilar

Género con 9 especies distribuidas desde Honduras hasta Colombia, Ecuador y Perú; sólo una registrada en Honduras (Morales, 1997a). Estudios moleculares recientes sugieren que este género podría ser considerado parte de Mesechites (Simões \& al., 2004).

1. Allomarkgrafia plumeriiflora Woodson, Ann. Missouri Bot. Gard. 20(4): 627. 1933

Tipo: Colombia. Boyaca: El Umbo, 1100 m, 13.X.1932 (fl), A. Lawrance 534 (holótipo, MO; isótipos, ARIZ, F [foto F neg. 56428], NY, US). (Figs. 3 A, $9 \mathrm{~A}, \mathrm{~B})$.

Liana. Hojas con la lámina 7,4-14,5 × 2,4-6,9 cm, elípticas a angostamente elípticas, el ápice apiculado o agudo, la base redondeada, pecíolo 9-16 mm de largo. Inflorescencia una cima con pocas a muchas flores, pedicelos 5-11 mm de largo, brácteas 2-3 mm de largo, diminutas, no foliáceas; sépalos 2-3,5 mm de largo, ovados; corola blanca a crema, parte inferior del tubo 0,8-1,3 cm de largo, inflado cerca de la base, la parte superior del tubo 6-10 $\mathrm{mm}$ de largo, angostamente campanulada, con un diámetro 10-12 mm en la fauce, lóbulos 1,3-2 × 0,9-1,2 cm, suberectos; anteras ca. 6 $\mathrm{mm}$ de largo, nectarios sobrepasando al ovario. Folículos 35-40 cm $\times$ 4-5 mm; semillas ca. $5 \mathrm{~mm}$ de largo, la coma 1-1,2 cm de largo.

Distribución. Honduras a Colombia. Bosques muy húmedos en elevaciones bajo los $300 \mathrm{~m}$. Especímenes con flores se registran en mayo.

Allomarkgrafia plumeriiflora se puede reconocer con facilidad por sus hojas con coléteres en la base del nervio central, con numerosas venas terciarias perpendiculares al nervio central, inflorescencias cimosas, con corolas blancas o crema, infundibuliformes y con un tubo inferior a $2,5 \mathrm{~cm}$ de largo. Anteriormente este género y especie se conocía desde Colombia al $\mathrm{S}$ de Nicaragua y se registra por primera vez para Honduras.

Espécimen representativo examinado. HONDURAS. Atlántida: campamento quebrada Grande, al SW de La Ceiba, 15.V.1993 (fl), Liesner \& Mejía 26373 (EAP, MO, TEFH).
3. Anechites Griseb, Fl. Brit. W. I. 410. 1861 [1864]

Lianas, con secreción acuosa o acuoso-lechosa, con tricomas rígidos y a veces uncinados en el ápice, sin espinas o aguijones, coléteres intrapeciolares diminutos. Hojas opuestas, eglandulares, la lámina con pelos esparcidos con bases multicelulares conspicuas, membranáceas, pecioladas. Inflorescencias racemosas, axilares, con pocas flores, brácteas escamiformes e inconspicuas; cáliz con 5 sépalos, similares, diminutos, con una línea de coléteres en la base; corola hipocraterimorfa, sin corona anular o lóbulos coronales libres, blancas, limbo con 5 lóbulos, con estivación sinistrorsa; estambres incluidos, insertos en la base del tubo, anteras libres y no aglutinadas a la cabeza estigmática, cabeza estigmática con lóbulos basales; gineceo bicarpelar, apocárpico, nectario anular, inconspicuo. Frutos folículos apocárpicos, levemente moniliformes, membranáceos, estrigoso-pubescentes, con pelos rígidos y usualmente uncinados en el ápice; semilla 1 , seca y desnuda, sin coma apical.

Género monotípico distribuido desde las Antillas y Honduras hasta Colombia y Ecuador (Fallen, 1983).

1. Anechites nerium (Aubl.) Urb., Repert. Spec. Nov. Regni. Veg. 16: 150. 1919

Apocynum nerium Aubl., Hist. Pl. Guiane 1: 277. 1775

Tipo: Antillas, Plumier, Bot. Amer. 1, Icon 70. 1689-1697. Lámina reproducida en Burman (ed.), Pl. Amer. fasc. 2: 19, tab. 26. 1756. (Fig. 9 C).

Lianas. Hojas con láminas 3,3-11,2 × 1,3-4,2 cm, angostamente ovadas o angostamente elípticas, el ápice agudo a cortamente acuminado, la base redondeada o levemente cordada, pecíolo 11-32 mm de largo. Inflorescencias con pedicelos de 6-8 $\mathrm{mm}$ de largo, brácteas 1 1,5 mm de largo, diminutas, no foliáceas; sépalos 1,5-2 mm de largo, ovados; corola con el tubo 5-9 $\times 1,5-2 \mathrm{~mm}$, lóbulos 5-10 ×5-8 mm, obovados; anteras ca. 1,5 mm de largo, nectario ca. 1/4 de la longitud del ovario. Folículos de 6,5-10,7 cm de largo; semillas 1,6-1,8 cm de largo.

Distribución. Bosques muy húmedos, bajo los 200 $\mathrm{m}$. Especímenes con flores se registran en diciembre.

Anteriormente, este género era desconocido en Honduras (Fallen, 1983; Morales, 2005a), pero el estudio de colecciones en los herbarios hondureños, han confirmado su presencia en este país. A pesar de tener una distribución relativamente amplia, Anechites es poco recolectado, debido principalmente al tamaño pequeño y color no llamativo de sus flores.

Espécimen representativo examinado. HONDURAS. Cortés: faldas de San Juan Lindo, cerca de Santa Ana, Cordillera de Omoa, 1.XII.1950 (fl), Molina 3483 (EAP). 

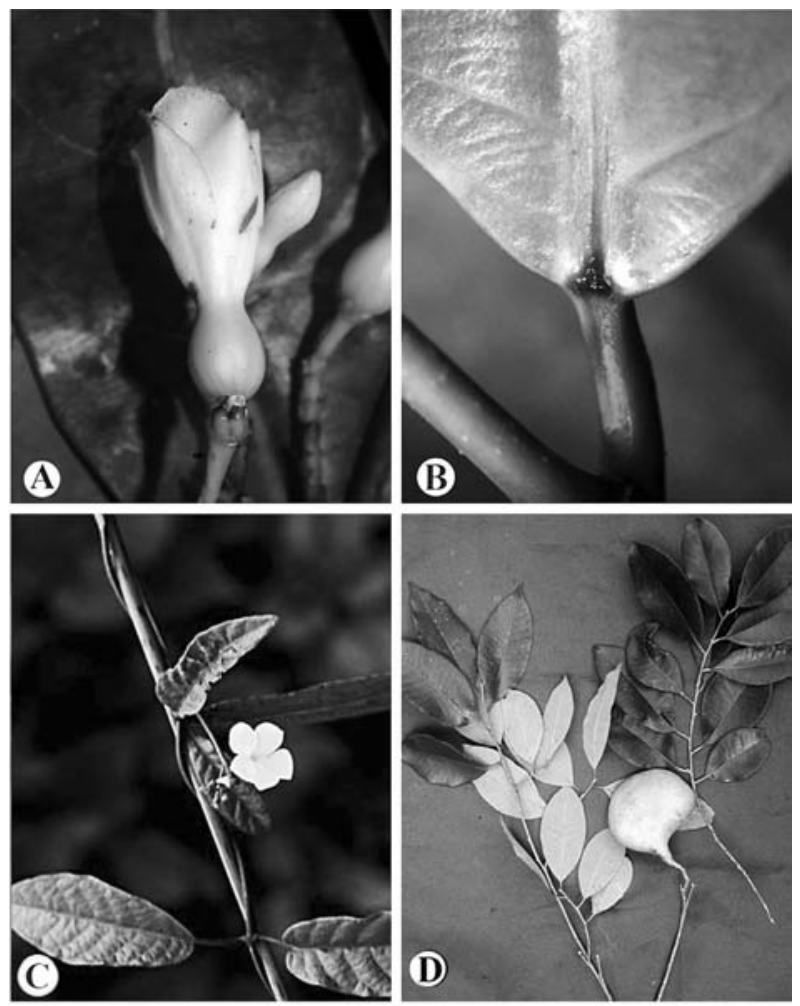

Fig. 9. Allomarkgrafia, Anechites y Aspidosperma. A,B, Allomarkgrafia plumeriiflora; C, Anechites nerium; D, Aspidosperma megalocarpon.

4. Aspidosperma Mart. \& Zucc., Flora 7(1) (beil. 4): 135. 1824, nom. cons.

Árboles o arbustos, tallos con secreción lechosa, cremosa, anaranjada o rojiza, algunas veces no evidente, glabros a pubescentes, sin espinas o aguijones, coléteres intrapeciolares no evidentes. Hojas alternas, raramente subopuestas u opuestas, eglandulares, la láminas glabra a pubescente, pecioladas a sésiles o subsésiles. Inflorescencias cimosas, corimbosas o tirsoides, axilares, subterminales a terminales o ramifloras, con pocas a muchas flores, brácteas escamiformes; cáliz con 4 a 6 lóbulos o raramente bilobulado, lóbulos similares, diminutos, sin coléteres; corola hipocraterimorfa, sin corona anular o lóbulos coronales libres, blanca, crema a blanco-verdosa o rojiza, raramente púrpura, limbo con 5 lóbulos, con estivación sinistrorsa; estambres incluidos, anteras no conniventes ni aglutinadas a la cabeza estigmática, cabeza estigmática capitada o claviforme; gineceo bicarpelar, apocárpico, de manera usual sin nectarios. Frutos folículos apocárpicos, pareados o solitarios, lisos, con surcos o costillas longitudinales o con proyecciones cónicas, leñosos; semillas comprimidas, aladas, numerosas (rara vez 2 ), no comosas.
Género con cerca de 46 especies distribuidas desde México y las Antillas hasta Argentina; 2 son conocidas en Honduras (Woodson, 1951; Marcondes-Ferreira, 1988). Aspidosperma polyneuron Mull. Arg. (Molina 10434, EAP) se ha cultivado esporádicamente en la estación experimental Lancetilla y no existe evidencia de que se haya cultivado en otras partes de Honduras. Este taxón, conocido de otro modo sólo de Sudamérica, se separa de las otras dos especies presentes en ese país por sus folículos oblongos y angostos.

1. Inflorescencia ramiflora; pedúnculo usualmente más de 2,5 cm de largo; cáliz bilabiado; folículos 5,5-8 cm de largo, lisos

1. A. megalocarpon

1. Inflorescencia (sub)terminal; pedúnculo usualmente menos de 1,5 cm de largo; cáliz pentalobulado; folículos de 12-16 de largo, con surcos longitudinales

2. A. desmanthum

1. Aspidosperma desmanthum Benth. ex Müll. Arg., Fl. Bras. 6(1): 51. 1860

Tipo: Brasil. Amazonas: cerca de Panuri, Rio Uaupes, oct-ene 1853 (fl), Spruce 2618 (holótipo, K; isótipos, BR, C [foto F neg 22249], GH, MO, W). (Fig. 10 B-D).

Aspidosperma cruentum Woodson, Amer. J. Bot. 22(7): 634. 1935

Tipo: Guatemala. Petén: Vacaxtum, 16.IV.1931 (fl), Bartlett 12750 (holótipo, MO; isótipos, MICH, NY, US).

Aspidosperma matudae Lundell, Phytologia 1(10): 339. 1939

Tipo: México. Chiapas: Escuintla, I.1938 (fl), Matuda 2030 (holótipo, MICH [foto, MO]; isótipos, A, CAS, F [foto F neg 64654], GH, LL, MO, NY, US). Aspidosperma chiapense Matuda, Madroño 10(6): 172-173. 1950

Tipo: México. Chiapas: Escuintla, La Esperanza, 15.II.1946 (fl), Matuda 16361 (holótipo, MEXU; isótipos, CAS, EAP, ENCB, F [foto F neg 64015], MICH, NY, US).

Aspidosperma chiapense Matuda f. tenax Matuda, Madroño 10(6): 173. 1950

Tipo: México. Chiapas: Escuintla, La Esperanza, 25.I.1948 (fl), Matuda 17386 (holótipo, MEXU; isótipos, F [foto F neg 63797], MICH, NY).

Árboles de 13-25 m de altura, tallos con secreción blanca o crema, tornándose rojiza por oxidación. Hojas con láminas 9,5-18,9 × 3,8-5,8 cm, elípticas o angostamente obovadas, el ápice obtuso o agudo, la base obtusa a redondeada, glabras en 1 haz, inconspicuamente puberulentas a glabrescentes en el envés, pecíolo $16-38 \mathrm{~mm}$ de largo. Inflorescencia terminal a 
subterminal, puberulenta, pedúnculos $26-89 \mathrm{~mm}$ de largo, pedicelos menos $2 \mathrm{~mm}$ de largo; cáliz con 5 lóbulos, 1,5-2 mm de largo, ovados, densamente tomentulosos; corola blanca a crema, glabrescente, tubo 3-4 $\mathrm{mm}$ de largo, lóbulos 3-4,5 × 1-1,5 mm, muy angostamente elípticos; anteras ca. $1 \mathrm{~mm}$ de largo. Folículos $12-16 \times 8-10 \mathrm{~cm}$, tomentulosos, con surcos longitudinales; semillas 8,5-10 cm de diámetro.

Distribución. S de México a Brasil y Bolivia. Bosques muy húmedos en elevaciones bajo los $400 \mathrm{~m}$. Especímenes con frutos se registran en agosto.

Nombres comunes. "Cañamito", "Mamba" (tawahka), "Yampus" (mískito) (Nelson, 2008).

La variación en la morfología foliar de esta especie es relativamente alta, lo que provoca que el tamaño de las hojas pueda variar notablemente en individuos de una misma población. Esta especie ha sido erróneamente conocida en México y Centroamérica como $A s$ pidosperma spruceanum (e.g., Morales 2005a, 2006a), la cual de otro modo solo se conoce de la amazonía en Suramérica.

Espécimen representativo examinado. HONDURAS. Gracias a Dios: al N de Krausirpe, 7.VIII.1994 (fr), House 2080 (TEFH).

2. Aspidosperma megalocarpon Müll. Arg., Linnaea 30: 400. 1860

Macaglia megalocarpa (Müll. Arg.) Kuntze, Revis.

Gen. Pl. 2: 416. 1891

Tipo: México. Veracruz: Colipa, 1841-1842 (fr), Karwinski 1348 (holótipo, LE). (Figs. 9 D, 10 A).

Árboles 10-18 m de altura, tallos con secreción crema a blanca. Hojas con láminas de 6,3-16,4 × 2,7-5,5 $\mathrm{cm}$, elípticas, el ápice agudo o corto acuminado, la base obtusa, glabras, pecíolo 5-15 mm de largo. Inflorescencia ramiflora, puberulenta, pedúnculos 2-14 $\mathrm{mm}$ de largo, pedicelos 1-4 mm de largo; cáliz bilabiado, los lóbulos 2-4 mm de largo, ovados, puberulentos; corola crema a anaranjada, papilosa, tubo 4-6 mm de largo, lóbulos 5-6 mm angostamente elípticos; anteras ca. $1 \mathrm{~mm}$ de largo. Folículos 5,7-7,9 × 5,5-6 cm, cremoso-escamosos, lisos; semillas 5-6 cm de diámetro.

Distribución. México a Panamá y Colombia. Bosques húmedos, bosques de galería, en elevaciones de 100-200 m. Especímenes con frutos se registran entre febrero y marzo.

Nombres comunes. "Chapel", "Chaperno", "Fustán de vieja” (Nelson, 2008).

Aspidosperma megalocarpon se distingue de A.desmanthum por sus inflorescencias ramifloras, así como por sus flores con el cáliz bilobulado y folículos más pequeños. Adicionalmente, $A$. megalocarpon crece en zonas con una estación seca más marcada y prolongada
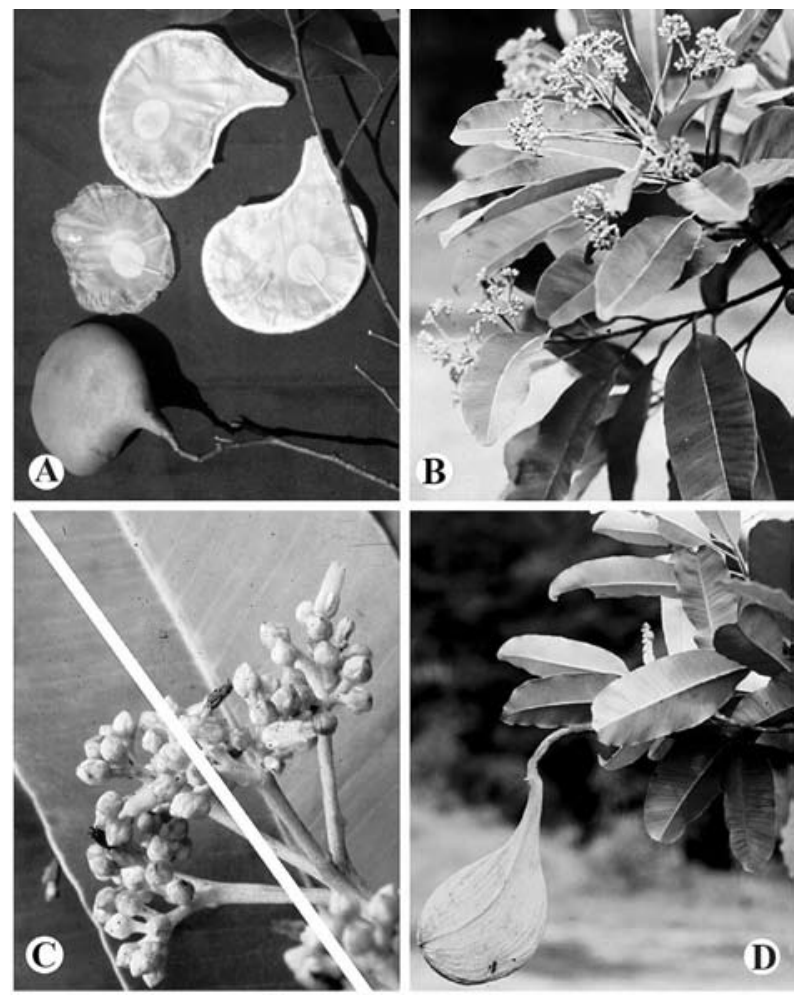

Fig. 10. Aspidosperma. A, A. megalocarpum; B-D, A. desmanthum.

que en las que se encuentra $A$. desmanthum. Aunque ambas especies de Aspidosperma han sido pobremente recolectadas en Honduras, en forma natural $A$. megalocarpon es menos abundante que $A$. desmanthum. Para una sinonimia más extensa véase Morales (2005a: 112).

Espécimen representativo examinado. HONDURAS. Comayagua: río Sulaco, al N de Santa Cruz de Yojoa, 18.II.1981 (fr), Nelson E al. 7648 (MO, TEFH).

\section{Beaumontia Wall., Tent. Fl. Napal. 14. 1824}

Lianas, tallos con secreción lechosa, pubescentes, sin espinas o aguijones, coléteres intrapeciolares diminutos. Hojas opuestas, eglandulares, pubescentes a glabrescentes, pecioladas. Inflorescencias cimosas, axilares a terminales o subterminales, con pocas a muchas flores, brácteas foliáceas; cáliz con 5 sépalos (raramente 6), similares, foliáceos, con varios coléteres en la base; corola infundibuliforme, sin corona anular o lóbulos coronales, blanca a crema, algunas veces con tonos rojizos en los lóbulos, limbo con 5 lóbulos, con estivación dextrorsa; estambres incluidos, anteras conniventes en un cono alrededor de la cabeza estigmática, ésta elipsoide a ovoide; gineceo bicarpelar, apocárpico, nectario anular. Frutos folículos apocárpicos, lisos, 
continuos, algo leñosos al madurar; semillas numerosas, secas, comosas y truncadas en el ápice micropilar.

Género con 9 especies de Asia tropical, India e Indonesia, una cultivada ocasionalmente en Honduras (Rudjiman, 1986).

1. Beaumontia grandiflora Wall., Tent. Fl. Napal. 1: 15-16, pl. 7. 1824

Tipo: Nepal. Noakote, Nawakot, Wallich 1629,1 (holótipo, K-WALL) (Fig. 11 A).

Liana, tallos ferrugíneo-tomentulosos, glabrescentes. Hojas con láminas 9,9-23 × 3,4-9,7 cm, elípticas a obovadas, el ápice cortamente acuminado, la base obtusa, puberulentas en el envés, pecíolo 9-20 mm de largo. Inflorescencia, con 2 a 3 flores, con indumento ferrugíneo, pedicelos 23-43 mm de largo, brácteas 11$21 \mathrm{~mm}$ de largo; sépalos de $42-53 \mathrm{~mm}$ de largo, obovados o elípticos; corola con la parte inferior del tubo de 1,8-2,3 cm de largo, la parte superior de 7-13 cm de largo, anchamente cónica a campanulada, de 4,5-6,3 $\mathrm{cm}$ de ancho en la fauce, lóbulos de 1,8-3,4 × 1,6-3,1 $\mathrm{cm}$, anchamente ovados; anteras ca. 1,6 cm de largo, ovario 3-4 mm de largo, nectario más corto que el ovario. Folículos 22-31 × 5-6 cm; semillas $15-25 \mathrm{~mm}$ de largo, coma 4-7 cm de largo.

Distribución. Nativa del E de India, pero cultivada en forma ocasional entre los 100-1200 m. Florece durante todo el año.

Nombres comunes. "Trompeta de heraldo" (Nelson, 2008).

Beaumontia grandiflora es una de las Apocynaceae cultivadas más llamativas en Mesoamérica por el tamaño de sus corolas, las más grandes entre los géneros nativos o introducidos y cultivados. Rara vez produce frutos, por lo que la descripción fue tomada de Rudjiman (1986).

Especimen representativo examinado. HONDURAS. Cortes: Jardín Pérez Estrada, San Pedro Sula, 1951 (fl), Pérez s.n. (EAP).

\section{Carissa L., Syst. Nat. (ed. 12) 2: 135, 189. 1767}

Arbustos o árboles pequeños, tallos con secreción lechosa, glabros a puberulentos, con presencia de espinas, algunas veces bifurcadas, coléteres intrapeciolares diminutos. Hojas opuestas, sin coléteres, la lámina glabra, pecioladas. Inflorescencias cimas axilares o reducidas a 1 ó 2 flores fasciculadas, usualmente con pocas flores, brácteas escamiformes; cáliz con 5 sépalos, similares, diminutos, eglandulares o raramente con pocos coléteres presentes; corola hipocraterimor$\mathrm{fa}$, sin corona anular o lóbulos coronales libres, blanca o crema, limbo con 5 lóbulos, con estivación sinistrorsa o destrorsa; estambres totalmente incluidos, anteras no conniventes ni aglutinadas a la cabeza estigmática, cabeza estigmática anchamente ovada, apenas diferenciada del estilo; gineceo sincárpico, nectario usualmente ausente. Frutos bayas sincárpicas, lisas, carnosos; semillas desnudas, usualmente pocas.

Género paleotropical con ca. 20 especies, una de ellas cultivada en Honduras (Gentry, 2001).

1. Carissa macrocarpa (Eckl.) A. DC., Prodr. 8: 336. 1844

Arduina macrocarpa Eckl., S. African J. Sci. 1: 372. 1830

Tipo: Sur África: cerca de Port Natal (no localizado). (Fig. 11 B).

Arbustos hasta $2 \mathrm{~m}$ de altura, tallos con espinas furcadas en los nudos. Hojas con láminas 2,8-6,9 × 1,9-4,1 $\mathrm{cm}$, elípticas a angostamente ovadas, el ápice apiculado o mucronado, la base obtusa o levemente cordada, glabras, pecíolo 1-3 mm de largo. Inflorescencia con pedicelos 2,5-3 mm de largo, brácteas ca. $1 \mathrm{~mm}$ de largo, diminutas, no foliáceas; sépalos 3-5 mm, angostamente ovados; corola blanca, tubo 0,9-1,5 cm de largo, ca. 2,5 mm de diámetro en la fauce, lóbulos 18-22 × 4$8 \mathrm{~mm}$, angostamente obovados; anteras 3-4 mm de largo, ovario 1,5-2 mm de largo. Frutos 1,9-2,8 × 1,4-2,8 $\mathrm{cm}$, rojos al madurar; semillas 6-8 $\mathrm{mm}$ de largo.

Distribución. Originaria de Sudáfrica, es conocida solo de cultivo en Honduras, en elevaciones entre los 900-1300 m. Produce flores durante todo el año.

Nombres comunes. "Ciruela de Natal" (Francisco Morazán).

En América tropical esta especie se ha cultivado en forma esporádica como arbusto ornamental y se puede reconocer por sus hojas notablemente coriáceas y espinas decusadas y bifurcadas presentes en los tallos. Sus frutos maduros son comestibles.

Espécimen representativo examinado. HONDURAS. Francisco Morazán: El Zamorano, 27.XI.1987 (fl), Molina 34043 (BIGU, EAP).

\section{Cascabela Raf., Sylva Tellur. 162. 1838}

Arbustos o árboles, tallos con secreción lechosa, glabros a puberulentos, los peciolos con coléteres axilares inconspicuos. Hojas alternas, espiraladas, eglandulares, glabras a puberulentas en la superficie abaxial, membranáceas, sésiles a pecioladas. Inflorescencias cimosas, axilares a subterminales, con pocas o muchas flores, brácteas escariosas, inconspicuas; cáliz con 5 sépalos, similares, subfoliáceos, con numerosos coléteres en la base; corola infundibuliforme, amarilla, sin corona anular, de manera usual glabra, el interior con cinco lóbulos coronales en forma opuesta sobre cada antera, 
limbo con 5 lóbulos, con estivación sinistrorsa; estambres incluidos, anteras no conniventes ni aglutinadas a la cabeza estigmática, cabeza estigmática con lóbulos basales; gineceo bicarpelar, apocárpico, con 2-4 óvulos, nectario anular y a veces lobulado. Frutos bayas sincárpicas, bayas, morados o rojo morados al madurar, el exocarpo carnoso o esponjoso, el mesocarpo leñoso; semillas 2-4, desnudas, no comosas.

Género con cerca de cinco especies distribuidas desde México hasta Sudamérica, tres presentes en Honduras (Alvarado-Cárdenas \& Ochoterena, 2007).

1. Hojas con las venas secundarias conspicuas; lámina con el ápice mucronado o apiculado; plantas siempre nativas

2. C. ovata

1. Hojas con las venas secundarias inconspicuas; lámina con el ápice agudo; plantas cultivadas o nativas (C. gaumeri) ...... 2

2. Hojas de 0,5-1 cm de ancho, linear-elípticas; parte inferior del tubo de la corola 1,5-1,8 cm de largo .......... 3. C. thevetia

2. Hojas de 1,4-2,9 cm de ancho, angostamente elípticas o angostamente obovadas; parte inferior del tubo de la corola 1,2$1,4 \mathrm{~cm}$ de largo

1. C. gaumeri

1. Cascabela gaumeri (Hemsl.) Lippold, Feddes Repert. 91(1-2): 53. 1980

Thevetia gaumeri Hemsl., Hooker's Icon. Pl. 16, P. 1517. 1886

Tipo: México. Quintana Roo: isla de Cozumel, 1885 (fl), Gaumer s.n. (holótipo, F). (Fig. 11 C).

Árboles o arbustos 3-5 m de altura, tallos glabros a puberulentos. Hojas con láminas 8,7-17,3 × 1,4-2,9 $\mathrm{cm}$, angostamente elípticas a angostamente obovadas, el ápice agudo, la base cuneada, glabras, nervadura secundaria apenas visible en el envés, pecíolo $0,8-1,8 \mathrm{~cm}$ de largo. Inflorescencia con 4-8 flores, pedicelos 2-4,7 $\mathrm{cm}$ de largo, brácteas 3-5 mm de largo; sépalos 7-13 $\mathrm{mm}$, angostamente ovados; corola infundibuliforme, (anaranjado-)amarilla, la parte inferior del tubo 1,2$1,4 \mathrm{~cm}$ de largo, la parte superior 1,1-1,3 cm de largo, cónica, 1,6-1,8 cm de diámetro en la fauce, lóbulos 2,5-4,8 × 2,2-2,9 cm, obovados; anteras 1,5-2 mm de largo, nectario apenas más corto que el ovario. Frutos $2-3 \mathrm{~cm}$ de ancho.

Distribución. México al $\mathrm{N}$ de Nicaragua. Conocido en Honduras aparentemente solo de cultivo, en elevaciones de 1000-1200 m. Especímenes con flores se registran entre octubre y mayo.

Nombres comunes. "Chilindrón" (Francisco Morazán, Olancho).

Cascabela gaumeri se puede confundir con la común C. thevetia, de la que se distingue por sus hojas más anchas y con pecíolos más largos, así como corolas con la parte inferior del tubo de $12-14 \mathrm{~mm}$ de largo. Aunque C. gaumeri es común en el $\mathrm{N}$ de Nicara-

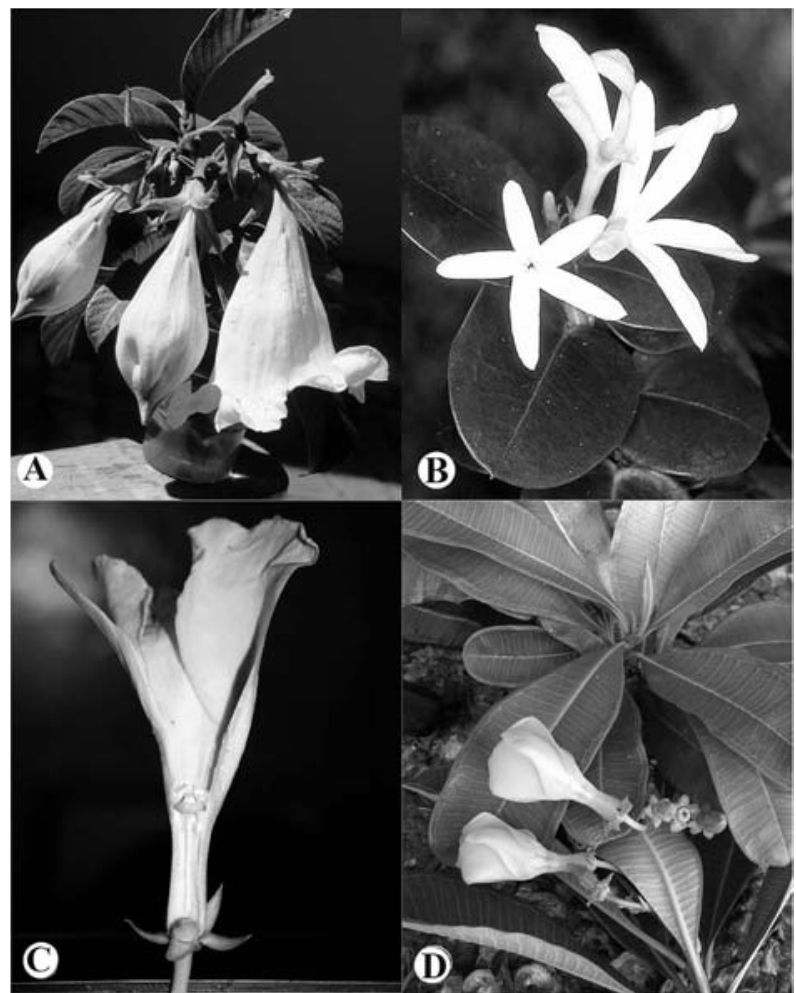

Fig. 11. Beaumontia, Carissa y Cascabela. A, Beaumontia grandiflora; B, Carissa macrocarpa; C, Cascabela gaumeri; D, C. ovata.

gua, aparentemente de Honduras sólo se conoce de cultivo. Para una mayor sinonimia véase AlvaradoCárdenas \& Ochoterena (2007).

Especímenes representativos examinados. HONDURAS. Choluteca: San José de las Conchas, 1.IV.1998 (fl), Gordon E Sandoval 202 (EAP). Francisco Morazán: cercanías del Suyapa, IX-XII1943 (fr), Standley 12412 (EAP). Olancho: cercanías de Juticalpa, 5.16.III.1949 (fl), Standley 17678 (EAP).

2. Cascabela ovata (Cav.) Lippold, Feddes Repert. 91(1-2): 53. 1980

Cerbera ovata Cav., Icon. 3: 35, t. 270. 1796

Thevetia ovata (Cav.) A. DC., Prodr. 8: 344.1844

Tipo: "Nueva España”, sin fecha (fl), Cavanilles s.n. (holótipo, MA) (Figs. 2 C, 4 A, 11 D, 12 A).

Thevetia plumeriifolia Benth, Bot. Voy. Sulphur. 124, t. 43.1845

Cascabela plumeriifolia (Benth.) Lippold, Feddes Repert. 91(1-2): 53. 1980

Tipo: Honduras. Valle: Golfo de Fonseca, sin fecha (fl), Sinclair s.n. (lectotipo, designado por Nelson (1996), K).

Arbusto 1,5-3 m, tallos glabros a puberulentos. Hojas con láminas 5,3-15,8 × 2,3-5,7 cm, angostamente elípticas a angostamente obovadas, el ápice mucrona- 
do o apiculado, la base cuneada, puberulentas o glabrescentes en la superficie abaxial, nervadura secundaria impresa, pecíolo 1,1-2,8 cm de largo. Inflorescencia con 2-6 flores, pedicelos 2,5-5,2 cm de largo, brácteas 4-6 mm de largo; sépalos 5-9 mm, ovados; corola infundibuliforme, amarilla, parte inferior del tubo 1,1-1,3 cm de largo, la parte superior $1-1,1 \mathrm{~cm}$, cónica, 1,2-1,4 cm de diámetro en la fauce, lobulos 2,2-4,1 ×2,2-3,4 cm, obovados; anteras 1,4-1,5 mm de largo; nectario tan largo como el ovario. Frutos 3-3,5 $\mathrm{cm}$ de ancho, rojo-morados a morados al madurar, semillas 1,6-2 cm de diámetro.

Distribución. México a Costa Rica. Bosques secos y vegetación secundaria relacionada entre 200-1200 m de elevación. Flores y frutos se registran durante todo el año.

Nombres comunes. "Chilindrón" (Choluteca); "Chirca" (Francisco Morazán); "Quiebramuelas" (Choluteca).

Esta especie se puede reconocer por sus prominentes venas secundarias, usualmente impresas y visibles en ambas caras. Puede llegar a formar poblaciones bastantes densas en algunas áreas, sobre todo en zonas de crecimiento secundario.

Especímenes representativos examinados. HONDURAS. Choluteca: al N de San Marcos, 27.IX.1973 (fl), Hazlett 931 (MO, TEFH). Comayagua: quebrada Chicúas, cerca del Agua Salada, 21.VII.1962 (fr), Molina 11008 (EAP). El Paraíso: camino a Oropolí, 10.VII.1961 (fl), Molina 10082 (EAP). Francisco Morazán: camino al Zamorano, 3.VIII.1946 (fl), Williams E Molina 10205 (EAP, MO). La Paz: valle de Comayagua, 28.III.1983 (fl, fr), Holst 988 (TEFH). Lempira: cerca de Las Flores, entre Santa Rosa de Copán y Gracias, 13.V.1987 (fl), Blackmore E Chorley 3910 (MO, TEFH). Ocotepeque: río Lempa, camino a Esquipulas, 29.VIII.1968 (fr), Molina 22437 (EAP). Olancho: cercanías de Juticalpa, 5-16.III.1949 (fl), Standley 17949 (EAP).

3. Cascabela thevetia (L.) Lippold, Feddes Repert. 91 (1-2): 52.1980

Cerbera thevetia L., Sp. Pl. 1: 209. 1753

Cerbera peruviana Pers., Syn. Pl. 1: 267. 1805, basado en C. thevetia

Cascabela peruviana (Pers.) Raf., Sylva Tellur. 162. 1838

Thevetia peruviana (Pers.) K. Schum., Nat. Pflanzenfam. 4(2): 159. 1895

Thevetia thevetia (L.) Millsp., Field Mus. Nat. Hist., Bot. Ser. 2(1): 83. 1900, nom. inval.

Thevetia peruviana (Pers.) Merr., Philipp. J. Sci. 9(2): 130. 1914, nom. illeg.

Cascabela thevetia (L.) Lippold, Feddes Repert. 91(12): 52.1980

Tipo: Habitat in America calidiore, sin fecha (fl), Herb. Linn. No. 298.1 (holótipo, BM [microficha, $\mathrm{MO}]$ ). (Fig. 12 B).
Arbusto 2-5 m, tallos glabros a glabrescentes. Hojas con láminas 3,2-12,4 × 0,5-1 cm, linear-elípticas, el ápice agudo, la base cuneadas, glabras, nervadura secundaria inconspicua, pecíolo 3-9 mm de largo. Inflorescencia con 1-5 flores, pedicelos 2,1-3,3 cm de largo, brácteas 3-4 mm de largo; sépalos 6-9 mm, ovados; corola infundibuliforme, amarilla, parte inferior del tubo 1,5-1,8 cm de largo, la parte superior $1,2-1,5 \mathrm{~cm}$ de largo, cónica, 1,5-1,6 cm de diámetro en la fauce, lóbulos 3,2-4,1 × 1,7-2,3 cm, obovados; anteras 1,5-2 $\mathrm{mm}$ de largo, nectario ca. la mitad de la longitud del ovario. Frutos 2,5-3,8 cm ancho, negro o morado al madurar, semillas 1,2-1,5 cm de diámetro.

Distribución. Originaria de América Tropical. En Honduras se cultiva como ornamental en prácticamente todo el país, en elevaciones de 0-1400 m. Flores y frutos se producen durante todo el año.

Nombres comunes. "Chila" (Francisco Morazán); "Chilco" (Choluteca); "Chilindrón" (Comayagua, Olancho, Yoro); "Codo de Monje" (Francisco Morazán); "Quiebramuelas" (Choluteca).

Cascabela thevetia es un arbusto que se ha cultivado ampliamente en zonas tropicales y subtropicales del mundo, debido a lo llamativo de sus flores y su capacidad de florecer en forma continua durante todo el año. No se conoce un origen definido, ya que el espécimen tipo no especifica ninguna localidad y, además, en la mayoría de países latinoamericanos sólo se conoce de cultivo $\mathrm{u}$ ocasionalmente escapada en bosques secundarios (e.g., Costa Rica). Sin embargo, es probable que este arbusto sea originario del N de Perú (e.g., Departamento de Piura), ya que algunas colecciones depositadas en el herbario de la Universidad de San Marcos (USM) en Lima, Perú, indican que crece en forma natural en algunas zonas de esa región.

Especimenes representativos examinados. HONDURAS. Choluteca: cercanías de Pespire, 18-27.X.1950 (fr), Standley 27137 (EAP). Comayagua: El Banco, 18.III.1945 (fl), Valerio 2512 (EAP). Cortés: alrededores de La Lima, al E de San Pedro de Sula, 12.X.1989 (fl, fr), Bueso 42 (TEFH). El Paraíso: El Paraíso, 19.IV.1996 (fl), Pastor 849 (EAP). Francisco Morazán: cercanías de Tegucigalpa, 7.XII.1949 (fl), Standley 24896 (EAP). Gracias a Dios: Mocorón, cerca Puerto Lempira, 30.I.1984 (fl), Padilla 203 (TEFH). Islas de la Bahía: Guanaja, 28.IV.1987 (fl), Pineda 154 (TEFH). Lempira: Gracias, 7-9.XII.1971 (fl, fr), Nelson E al. 304 (MO, TEFH). Olancho: aldea Casas Viejas, al NO de Juticalpa, 13.IV.1985 (fl), Alvarado 164 (TEFH). Valle: San Lorenzo, 26.VIII.1945 (fl), Valerio 3244 (EAP). Yoro: sabana El Coco, al E de Yoro, 1.I.1956 (fl), Johannessen 723 (EAP).

8. Catharanthus G. Don, Gen. Hist. 4: 71, 95. 1837

Hierbas arbustivas, tallos con secreción acuosa, glabros o pubescentes, sin espinas o aguijones, coléteres interpeciolares diminutos. Hojas opuestas, eglandulares, la lámina glabra o pubescente, pecioladas a subsé- 
siles. Inflorescencias cimosas, axilares, con 1 a 4 flores, brácteas escamiformes; cáliz dividido en 5 sépalos, similares, diminutos, sin coléteres en la base; corola hipocraterimorfa, sin corona anular o lóbulos coronales, de colores diversos, incluso variegados, limbo con 5 lóbulos, con estivación sinistrorsa; estambres incluidos, anteras no conniventes ni aglutinadas a la cabeza estigmática, la cabeza estigmática pentagonal; gineceo bicarpelar, apocárpico, nectarios 2, alternados con los carpelos. Frutos folículos apocárpicos, diminutamente sulcados longitudinalmente, membranosos; semillas numerosas, desnudas y secas, no comosas.

Género con 8 especies, la mayoría endémicas de Madagascar, una de ellas cultivada en Honduras (Bergen, 1996).

\section{Catharanthus roseus (L.) G. Don., Gen. Hist. 4: 95. 1837}

Vinca rosea L., Syst. Nat. (ed. 10) 2: 944. 1759

Lochnera rosea (L.) Rchb. ex Endl., Gen. Pl. 583. 1838

Tipo: Madagascar, Java, sin fecha (fl), Miller, Fig. Pl. Gard. Dict., 2: t. 186, 1757 [lectótipo, designado por Codd (1963)]. (Fig. 12 C,D).

Planta hasta $1,2 \mathrm{~m}$ de altura, tallos puberulentos a glabrescentes. Hojas con láminas 2,3-6,8 × 0,8-2,9 cm, angostamente elípticas a angostamente obovadas, el ápice mucronado a obtuso, la base cuneada, puberulentas a glabrescentes, pecíolo 2-12 mm de largo. Flores con pedicelos 2-3 mm de largo, brácteas ca. $1 \mathrm{~mm}$ de largo; sépalos de 2-6 mm de largo, angostamente ovados; corola blanca, lila, rosada o rojiza o variegada con varios colores, tubo 2-2,5 cm de largo, ca. $2 \mathrm{~mm}$ de diámetro en la fauce, lóbulos 1,4-2,3 × 1,4-2,1 cm, obovados; anteras ca. 2,5 mm de largo, nectarios tan largos como el ovario. Folículos 1,7-3,3 × ca. 0,2 cm; semillas ca. $2 \mathrm{~mm}$ de largo.

Distribución. Originaria de Madagascar. Cultivada en todo el país, en elevaciones de 0-1500 m. Flores y frutos se producen durante todo el año.

Nombres comunes. "Chula" (Intibucá); "Chulita" (Copán); "Mariposa”, "Pervinca" (Francisco Morazán,); "Mulatillo" (Intibucá); "Oajaca" (Atlántida); "Oaxaca" (Olancho); "Primorosa" (Choluteca); "Ramgoat" (Islas de la Bahía,); "Señorita" (Santa Bárbara). Nelson (2008) reporta los siguientes nombres: "Chuladita"; "Clavellina"; "Mulata"; "Primorosa morada". Usos: "La decocción de las hojas es empleada en el tratamiento de las inflamaciones de la garganta, especialmente cuando se inflaman las amígdalas. El medicamento es sólo gargarizado, no tomarlo" (Molina 1954, EAP).
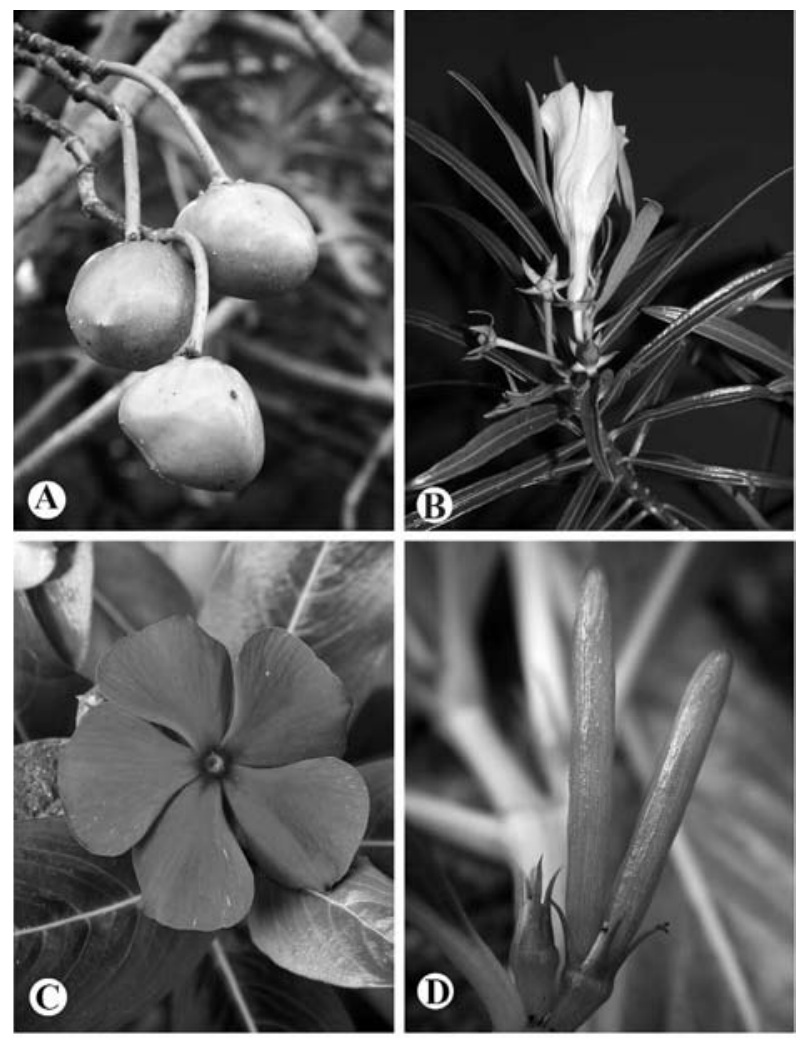

Fig. 12. Cascabela y Catharanthus. A, Cascabela gaumeri; B, C. ovata; C,D, Catharanthus roseus.

Catharanthus es probablemente junto con Allamanda y Plumeria los géneros más ampliamente cultivados en los trópicos y subtrópicos y presenta una amplia variedad de formas en relación con la coloración de la corola.

Especímenes representativos examinados. HONDURAS. Atlántida: Salado, 17.VII.1991 (fl), Nelson 11385 (TEFH). Choluteca: cercanías de San Marcos de Colón, 12-22.I.1949 (fl, fr), Standley 15939 (EAP). Colón: Trujillo, 30.XII.1980 (fl), Saunders 771 (MO). Comayagua: Agua Blanca, 5.III.1981 (fl), Lentz 439 (TEFH). Copán: Santa Rita, 6.I.1983 (fl, fr), Molina E al. 33673 (EAP). Cortes: Laguna Ticamaya, 1.V.1984 (fl, fr), Andino 172 (MO). El Paraíso: al S de El Paraíso, 20.IV.1996 (fl, fr), Pastor 852 (EAP). Francisco Morazán: El Jicarito, río Caparrosa, 13.VIII.1949 (fl, fr), Standley 22540 (EAP). Intibucá: Aldea San Juan de Magdalena, 10.I.1973 (fl, fr), Martínez 87 (MO, TEFH). Islas de la Bahía: Isla de Guanaja, 27.IV.1987 (fl), Nelson 9978 (TEFH). La Paz: al E de Marcala, 13.IX.1985 (fl), Ramos 60 (TEFH). Olancho: cercanías de Juticalpa, 5-16.III.1949 (fl), Standley 17682 (EAP). Santa Bárbara: Trinidad, 13.X.1990 (fl, fr), Sagastume 72 (EAP). Yoro: Aldea Quebrada Seca, El Progreso, 8.V.1983 (fl), Gómez 238 (MO).

9. Echites P. Browne. Civ. Nat. Hist. Jamaica 182. 1756

Allotoonia J.F. Morales \& J.K. Williams, Sida 21(1): 135. 2004 
Lianas, tallos con secreción acuosa o lechosa, glabros a puberulentos, sin espinas o aguijones, coléteres intrapeciolares diminutos. Hojas opuestas, eglandulares, las láminas glabras o inconspicuamente puberulentas, pecioladas. Inflorescencias cimosas, axilares, con pocas a muchas flores, brácteas escamiformes; cáliz con 5 sépalos, similares, diminutos, con 1 coléter en la base; corola hipocraterimorfa, sin corona anular o lóbulos coronales libres, rojizas, anaranjadas, amarillas o blancas, limbo con 5 lóbulos, con estivación dextrorsa; estambres incluidos, anteras conniventes y aglutinadas a la cabeza estigmática, cabeza estigmática con forma de carrete de hilo, con una anillo basal; gineceo bicarpelar, apocárpico, nectarios 5, separados o fusionados en la base y formando un nectario anular y pentalobulado. Frutos folículos apocárpicos, continuos a levemente moniliformes, membranáceos; semillas numerosas, secas, rostradas y comosas en el ápice micropilar.

Género con cerca de 10 especies del S de Estados Unidos (Florida) a Panamá y las Antillas, cinco de ellas presentes en Honduras (Morales, 1997b, 2008). La sinonimia completa de las especies de este género puede ser consultada en Morales \& Williams (2004, 2005).

1. Lóbulos de la corola torcidos en espiral distalmente, más largos que anchos ........................................................ 2

1. Lóbulos de la corola no torcidos en espiral, más o menos similares en longitud y ancho .......................................... 3

2. Tubo de la corola torcido en espiral en la posición de las anteras; anteras 11-12 mm de largo (Islas de la Bahía) ....

4. E. umbellatus

2. Tubo de la corola recto, no torcido en espiral; anteras $7-8 \mathrm{~mm}$ de largo (territorio continental) ........... 6. E. yucatanensis

3. Lóbulos de la corola 20-25 mm de largo (áreas entre 1500$2000 \mathrm{~m}$ )

2. E. turbinatus

3. Lóbulos de la corola 6-15 mm de largo (áreas entre 300-900 m)

4. Lóbulos de la corola más cortos que el tubo, ápice de los botones florales agudo o inconspicuamente apiculado; tubo de la corola 8-10 mm de largo .................... 3. E. tuxtlensis

4. Lóbulos de la corola más largos que el tubo; ápice de los botones florales obtuso a redondeado; tubo de la corola 3,5-7 $\mathrm{mm}$ de largo ......................................................... 5

5. Lóbulos de la corola glabros a glabrescentes en la superficie adaxial, rojo oscuro, rojo-púrpura a púrpura ....... 1. E. sp. A

5. Lóbulos de la corola densamente pubescentes en la superficie adaxial, anaranjados a rojizos ....... 5. E. woodsonianus

\section{Echites sp. A}

Lianas, tallos glabros. Hojas con láminas 7,9-8,5 × 3,3-4 cm, elípticas, el ápice cortamente acuminado, la base redondeada, pecíolo 8-11 mm largo. Inflorescencia con pocas flores, pedicelos 1,9-2,2 cm de largo, brácteas ca. $1 \mathrm{~mm}$ de largo, diminutas, no foliáceas; sépalos ca. $1 \mathrm{~mm}$ de largo, ovados; corola rojo-púrpura, rojo oscuro a púrpura, tubo 6-7 $\mathrm{mm}$ de largo, lóbulos 12-15 mm de largo, glabros a glabrescentes en la cara adaxial, pero densamente hirsutos en la base, justo alrededor de la fauce; anteras ca. $3 \mathrm{~mm}$ de largo, nectarios más cortos que el ovario. Folículos desconocidos.

Distribución. Guatemala, Honduras y El Salvador. Bosques estacionalmente secos, formaciones de roble-pino, en elevaciones de 300-900 m. Especímenes con flores han sido recolectados en junio y agosto.

Este taxón fue tratado como Allotoonia caudata en el tratamiento de las Apocynaceae de El Salvador (Morales, 2006a), pero el estudio reciente de poblaciones en ese país y Costa Rica lleva a la conclusión de que tres especies distintas han sido tratadas con el mismo nombre, las cuales se pueden reconocer con facilidad por la coloración de los lóbulos de la corola: Echites puntarenensis (antes A. caudata) (Costa Rica y Nicaragua) tiene flores verdes, a veces con tintes rojizos o amarillentos, mientras que otra especie sin describir (Costa Rica) tiene flores totalmente blancas, y la que está presente en Honduras, Guatemala y El Salvador tiene corolas rojopúrpura, rojo oscuro a púrpuras.

Espécimen representativo examinado. HONDURAS. Francisco Morazán: quebrada Jicarito, 13.VIII.1947 (fl), Molina 485 (EAP, F).

2. Echites turbinatus Woodson, Ann. Missouri Bot. Gard. 21: 615. 1934

Allotoonia turbinata (Woodson) J.F. Morales \& J.K. Williams, Sida 21(1): 150. 2004

Tipo: Costa Rica. Alajuela: Rancho Flores, 22.II.1890 (fl), A. Tonduz 2147 (lectótipo, designado por Morales \& Williams (2004), US; isolectótipos, BR [2 pliegos]).

Lianas, tallos glabros. Hojas con láminas 4,9-15,5 × 2,3-8,5 cm, elípticas, el ápice acuminado, la base obtusa, el pecíolo 8-14 mm de largo. Inflorescencia con muchas flores, pedicelos 7-10 mm de largo, brácteas 2,5-3 mm de largo, diminutas, no foliáceas; sépalos 23,5 mm de largo, ovados; corola verde, tubo 4-6 mm de largo, lóbulos 20-25 mm de largo, glabros a glabrescentes; anteras ca. $4 \mathrm{~mm}$ de largo, nectarios más cortos que el ovario. Folículos 21-29 cm de largo, levemente moniliformes; semillas $2,5-3 \mathrm{~cm}$ de largo, coma 4,5-5,5 cm de largo.

Distribución. México (Chiapas), Honduras, Costa Rica y Panamá. Bosques muy húmedos entre 1500$2000 \mathrm{~m}$. La floración se ha registrado en abril.

En el género Echites, esta especie se puede reconocer con facilidad por la longitud de los lóbulos de la corola y su distribución altitudinal restringida a bosques montanos sobre los $1500 \mathrm{~m}$.

Espécimen representativo examinado. HONDURAS. Cortéz: Montaña Idalfonso, N de Cofradía, 17.IV.1957 (fl), Molina 6203 (EAP, F). 
3. Echites tuxtlensis Standl., Contr. U.S. Natl. Herb. 23: 1164.1924

Allotoonia tuxtlensis (Standl.) J.F. Morales \& J.K. Williams, Sida 21(1): 153. 2004

Tipo: México. Chiapas: cerca de Tuxtla, 1.IX.1895 (fl), E. Nelson 3080 (holótipo, US).

Lianas, tallos glabros. Hojas con láminas 4,7-10,5 × 1,6-4,1 cm, angostamente elípticas a angostamente ovadas, el ápice acuminado, la base obtusa, pecíolo 3 $9 \mathrm{~mm}$ de largo. Inflorescencias con numerosas flores, pedicelos 0,8-1,7 cm de largo, brácteas ca. 1,5 mm de largo, diminutas, no foliáceas; sépalos 1,5-1,8 mm de largo, ovados; corola amarillo-crema a verde-crema, tubo 8-10 mm de largo, lóbulos 6-8 mm de largo, glabros; anteras ca. $4 \mathrm{~mm}$ de largo, nectarios ligeramente más cortos que el ovario. Folículos 13,2-14,5 cm × 1-3 $\mathrm{mm}$, continuos, glabros; semillas $11-13 \mathrm{~mm}$ de largo, la coma 2,7-3,2 cm de largo.

Distribución. S de México, Belice, Guatemala, Honduras y El Salvador, en elevaciones de 550-650 m. Especímenes con flores han sido recolectados en agosto.

Esta especie se reconoce fácilmente por sus corolas con los lóbulos más cortos que el tubo, así como el tubo de 8-10 mm de longitud.

Espécimen representativo examinado. HONDURAS. Ocotepeque: río Lempa, camino a Esquipulas, 29.VIII.1968 (fl), Molina 22423 (EAP, F, NY).

4. Echites umbellatus Jacq., Enum. Syst. Pl. 13. 1760

Tipo: Jacquin, Select. Stirp. Amer. Hist. t. 22. 1763 (lectótipo, designado por Morales [1997b]). (Fig. 13 A).

Liana, tallos glabros o puberulentos. Hojas con láminas 3,5-8,9 × 2,2-5,2 cm, elípticas, ovadas a orbiculares, el ápice redondeado y mucronado, la base obtusa o redondeada, glabras, pecíolo 4-13 mm de largo. Inflorescencia a veces reducida a una flor solitaria, pedicelos 1,2-4,5 cm de largo, brácteas 1,5-3 mm de largo; sépalos 2,5-3 mm de largo, ovados; corola blanca, glabra, tubo 3,9-5, $4 \mathrm{~cm}$ de largo, torcido en espiral sobre las anteras, 3-4 mm de diámetro en la fauce, lóbulos 1,6-2,8 × 0,6-2,2 cm; anteras 11-12 mm de largo, ovario 2,3-3 mm de largo, nectarios 1,5-1,8 mm de largo. Folículos 7,8-22,7 cm $\times 8-10 \mathrm{~mm}$, continuos; semillas 5,2-6,3 cm de largo, la coma 1,7-3 cm de largo.

Distribución. S de Estados Unidos (Florida), las Antillas, México, Belice y Honduras. Bosques secos y costeros en elevaciones bajo los $50 \mathrm{~m}$. La floración se ha registrado en junio.

Echites umbellatus en Honduras es conocida únicamente del Departamento de las Islas de la Bahía. La variación en la forma de la inflorescencia, así como en el número de flores y tamaño de las corolas, es bastante notable en este taxón.

Espécimen representativo examinado. HONDURAS. Islas de la Bahía: Isla Santillana, 10.VI.1986 (fl), Nelson E al. 9719 (MO, TEFH).

5. Echites woodsonianus Monach., Bull. Torrey Bot. Club. 86: 245, f. 1.1959

Prestonia woodsoniana (Monach.) A.H. Gentry, Ann. Missouri Bot. Gard. 70: 205. 1983

Allotoonia woodsoniana (Monach.) J.F. Morales \& J.K. Williams, Lankesteriana 5(2): 119. 2005

Tipo: México. Michoacán: Apatzingan, 13.X.1939 (fl), G. Hinton 15325 (holótipo, NY; isótipos, GH, MO, NY, TEX, US [2 pliegos]).

Lianas, tallos glabros. Hojas con láminas 3,4-10,8 × 1-3,2 cm, elípticas a angostamente ovadas, el ápice cortamente acuminado, la base cuneada a obtusa, pecíolo 0,3-1,3 cm de largo. Inflorescencia con numerosas flores, pedicelos 2-8 mm de largo, brácteas ca. 1,5 mm de largo; sépalos 1-1,5 mm de largo, ovados; corola anaranjada o rojiza, tubo 3,5-5 mm, lóbulos 9-14 mm de largo, densamente pubescentes en la superficie adaxial; anteras 3-4 mm de largo, nectarios más cortos que el ovario. Folículos de $32-38 \mathrm{~cm}$ de largo, continuos; semillas de 21-26 mm de largo, coma 3,8-4,2 cm de largo.

Distribución. México, Guatemala, Honduras, Nicaragua y Costa Rica. Bosques secos y vegetación perturbada relacionada en elevaciones de 300-650 m. Especímenes con flores han sido recolectados en julio, septiembre y noviembre.

Esta especie se puede reconocer por el indumento denso y erecto presente en la superficie adaxial de los lóbulos de la corola.

Especímenes representativos examinados. HONDURAS. Comayagua: quebrada Chicuas, cerca de el Agua Salada, 21.VII.1962 (fl), Molina 10996 (EAP, F, NY). La Paz: al NE de La Paz, 9.XI.1982 (fl), Holst 512 (EAP).

6. Echites yucatanensis Millsp., Publ. Field Columbian Mus., Bot. Ser. 8(1): 35. 1930

Tipo: México. Yucatán: Chichankanab, sin fecha (fl), G. F. Gaumer 1979 (holótipo, F; isótipos, C, MA, MO, NY, S). (Fig. 13 b).

Echites turriger Woodson, Ann. Missouri Bot. Gard. 19:381. 1932

Tipo: Guatemala. Zacapa: Gualán, 20.VI.1909 (fl), C. Deam 6376 (holótipo, MO; isótipos, $\mathrm{F}$ [foto F neg. 51101], NY, US [foto F neg. 44589]).

Liana, tallos glabros a puberulentos. Hojas con láminas 4,4-15,2 × 2,2-9,5 cm, ovadas, elípticas o pandura- 
das, el ápice acuminado, la base obtusa o redondeada, a veces levemente puberulentas abaxialmente, el pecíolo 1,1-3,4 cm de largo. Inflorescencia con pocas a muchas flores, pedicelos 0,9-2,7 cm de largo, brácteas 1,54,5 mm de largo; sépalos 2-5 mm de largo, ovados; corola blanca o crema, glabra o puberulenta, tubo 2,7-5,1 $\mathrm{cm}$ de largo, recto, sin torciones, 3-4 mm de diámetro en la fauce, lóbulos 1,8-3,3 × 1,1-2,1 cm; anteras 7-8 $\mathrm{mm}$ de largo, ovario 2-2,4 $\mathrm{mm}$ de largo, nectario anular o lobulado, tan largo como el ovario. Folículos 18,8-28 $\mathrm{cm} \times 5-8 \mathrm{~mm}$, continuos; semillas 1,7-1,9 cm de largo, la coma 2,4-3,3 cm de largo.

Distribución. México a Nicaragua. Bosques secos, vegetación xerofítica y vegetación secundaria relacionada en elevaciones de 400-1100 m. La floración se ha registrado de abril a octubre.

Esta especie es relativamente común en Honduras, donde se puede reconocer por sus hojas sin coléteres en la superficie abaxial, inflorescencias cimosas, con las flores aglomeradas, corolas hipocraterimorfas, las anteras insertas cerca de la mitad de la longitud total del tubo, así como folículos continuos.

Especimenes representativos examinados. HONDURAS. Choluteca: quebrada Tolobre, entre Morolica y Tolobre, 18.VI.1964 (fl), Molina 14228 (EAP). Comayagua: río Selguapa, El Taladro, 27.VI.1964 (fl), Molina 14316 (EAP). Cortés: entre La Sabana y Villa Nueva, 25.VII.1965 (fl), Dickson 1604 (EAP). El Paraíso: carretera Oropolí, río Oropolí, 10.VII.1961 (fl), Molina 10076 (EAP). La Paz: al N de La Paz, 13.IV.1983 (fl), Holst 1029 (TEFH). Olancho: quebrada Jaguitas, cerca de Santa María del Real, valle de Catacamas, 29.IV.1957 (fl), Molina 8420 (EAP). Santa Bárbara: río Ulúa, entre Ilama y Gualala, 23.VIII.1968 (fl), Molina 22055 (EAP). Yoró: Arsenal, al S del camino a Jocón, 22.V.1987 (fl), Blackmore \& Chorley 4080 (TEFH).

10. Fernaldia Woodson, Ann. Missouri Bot. Gard. 19(1): 48.1932

Lianas, tallos con secreción acuosa, glabros a puberulentos, coléteres interpeciolares diminutos. Hojas opuestas, eglandulares, la lámina glabra o pubescente, pecioladas. Inflorescencia racemosa, axilar, con numerosas flores, brácteas escamiformes e inconspicuas; cáliz con 5 sépalos, similares, diminutos, con 1 coléter en la base; corola infundibuliforme, sin corona anular o lóbulos coronales, blanca, blanco-crema a blanco-verdosa o crema, limbo con 5 lóbulos, con estivación dextrorsa, los lóbulos con conspicuos pelos blancos en el márgen; estambres incluidos, anteras conniventes y aglutinadas a la cabeza estigmática, cabeza estigmática con forma de carrete de hilo, con un anillo membranoso basal; gineceo bicarpelar, apocárpico, nectarios separados o fusionados en la base y formando un nectario pentalobulado. Frutos folículos apocárpicos, lisos. continuos, levemente leñosos; semillas numerosas, secas, rostradas y comosas en el ápice micropilar.
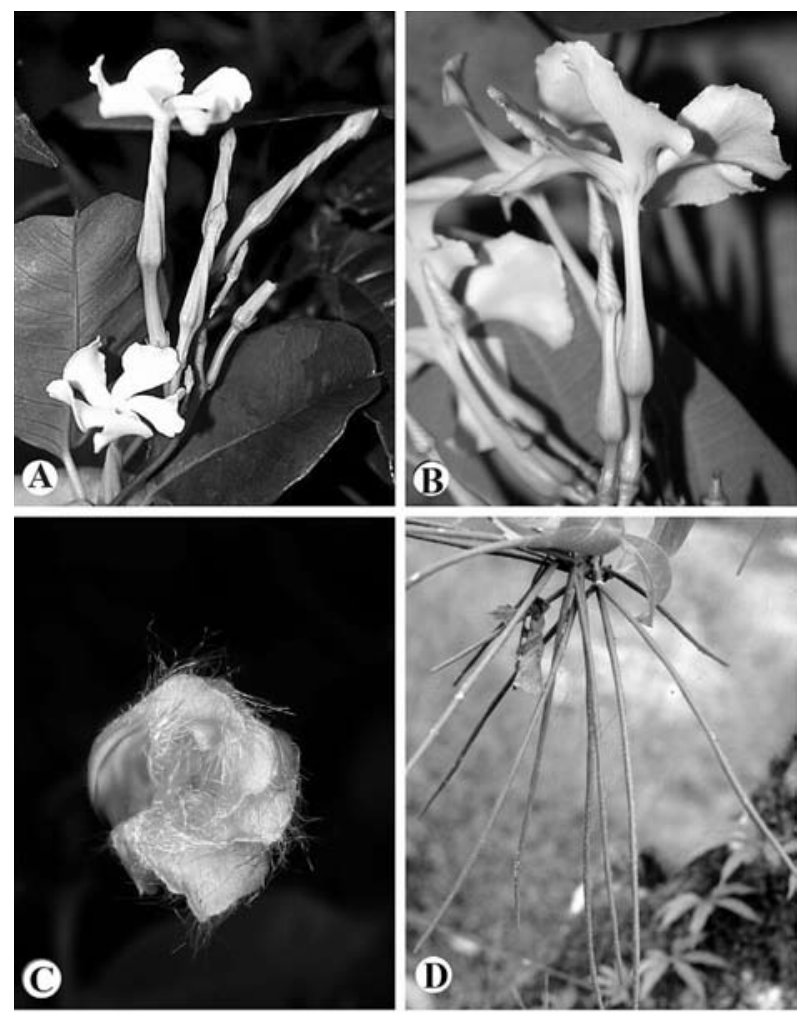

Fig. 13. Echites, Fernaldia y Forsteronia. A, Echites umbellatus; B, E. yucatanensis; C, Fernaldia pandurata; D, Forsteronia myriantha.

Fernaldia comprende 3 especies distribuidas desde México al NE de Panamá, una sola conocida en Honduras (Morales, 2002). Estudios filogéneticos recientes (Livshultz \& al., 2007) sugieren que este género debe ser reducido a la sinonimia de Echites.

1. Fernaldia pandurata (A. DC.) Woodson, Ann. Missouri Bot. Gard. 19: 48. 1932

Echites panduratus A. DC., Prodr. 8: 458. 1844

Amblyanthera pandurata (A. DC.) Müll. Arg., Linnaea 30: 448. 1860

Angadenia pandurata (A. DC.) Miers, Apocyn. S. Am. 182. 1878

Tipo: México. Oaxaca: San Dionisio, VIII.1832 (fl), Andrieux 245 (lectotipo, seleccionado por Morales (2002), G-DC [foto F neg. 7559]; isolectótipo, K). (Fig. 13 C).

Liana, tallos esparcidamente puberulentos a glabrescentes. Hojas con láminas 5,3-15,9 × 4,3-10,2 cm, ovadas, angostamente elípticas a panduradas, el ápice acuminado, la base redondeada, obtusa o levemente cordada, glabras o glabrescentes en el haz, pubescentes (raramente glabras) en el envés, pecíolo 10-38 mm de largo. Inflorescencia con pedicelos 4-10 $\mathrm{mm}$ de largo, brácteas 1,5-3 mm de largo; sépalos 1,5-3 mm, 
ovados; corola con parte inferior del tubo $18-21 \mathrm{~mm}$ de largo, la parte superior 10-15 mm de largo, cónica, 8-10 mm de diámetro en la fauce, lóbulos 9-13 × 9-10 $\mathrm{mm}$, obovados; anteras 5-6 mm de largo, nectario ca. $1,5 \mathrm{~mm}$ de largo, más corto que el ovario. Folículos de $22,3-34,5 \times 0,5-0,6 \mathrm{~cm}$; semillas 1,4-1,6 $\times$ ca. $0,2 \mathrm{~cm}$, coma 4-4,5 cm de largo.

Distribución. México a Costa Rica. Bosques secos y estacionalmente secos, en elevaciones de 50-1200 m.

Nombres comunes. "Loroco" (Cortes, Francisco Morazán); "Cuchampercitos", "Oloroco" (Nelson, 2008).

Fernaldia pandurata es relativamente sencilla de reconocer por la siguiente combinación de caracteres: hojas sin coléteres en el nervio central, inflorescencias sin ramificaciones, con las brácteas escamiformes, no foliáceas y los lóbulos de la corola con conspicuos pelos blancos en el margen. Las flores han sido ampliamente usadas en la confección de una serie de platillos y comidas típicas en Guatemala, El Salvador y Honduras. De hecho, la savia secretada por los tallos tiene un sabor dulce y con un olor similar al de Ficus carica L. (Moraceae). Una detallada referencia sobre los usos de esta especie se encuentra en el trabajo de Morton \& al. (1990). Para mayor referencia sobre su sinonimia, véase Morales (2005a).

Especimenes representativos examinados. HONDURAS. Choluteca: cercanías de Pespire, 18-27.X.1950 (fl), Standley 27079 (EAP). Comayagua: Agua Caliente, vaguada de ríos Chamo y Humuya, 22.XI/31.XII.1980 (fr), Nelson E al. 6230 (MO, TEFH). Copán: quebrada Seca, entre las ruinas de Copan y Santa Rita, 19.XI.1969 (fl), Molina \& Molina 24650 (EAP). El Paraíso: río California, Sierra de la Villa Santa, 31.XII.1950 (fr), Standley 28130 (EAP). Francisco Morazán: Villa San Roque, IX.1948 (fl), Standley 26257 (BM, EAP, F). Ocotepeque: San Marcos de Ocotepeque, 8-10.III.1974 (fr), Nelson E al. 1668 (TEFH).

11. Forsteronia G. Mey., Prim. Fl. Esseq. 133. 1818

Lianas o arbustos escandentes, tallos con secreción lechosa o acuoso-lechosa, glabros a pubescentes, sin espinas o aguijones, coléteres interpeciolares diminutos. Hojas opuestas, usualmente con coléteres en el nervio central, algunas veces eglandulares, láminas glabras a pubescentes, sésiles a pecioladas. Inflorescencia en panículas o tirsoides terminales o subterminales, con muchas flores, brácteas escamiformes; cáliz con 5 sépalos, similares, diminutos, con varios coléteres en la base, rara vez ausentes; corola rotada a subcampanula$\mathrm{da}$, sin corona anular o lóbulos coronales libres, blanca, blanco-verdosa, crema o amarilla, raramente rojiza, limbo con 5 lóbulos, con estivación dextrorsa; estambres exsertos o incluidos, con filamentos libres o coalescentes alrededor del estilo, anteras conniventes y aglutinadas a la cabeza estigmática, cabeza estigmática anchamente fusiforme; gineceo bicarpelar, apocárpi- co, nectario entero a lobulado, con 2, 3 ó 5 lóbulos. Frutos folículos apocárpicos, lisos, continuos o moniliformes, membranáceos; semillas numerosas, secas, truncadas y comosas en el ápice micropilar.

Género con ca. 42 especies distribuidas desde México y las Antillas hasta Argentina; 2 registradas en Honduras (Hansen, 1985).

1. Sépalos ca. $1 \mathrm{~mm}$ de largo; inflorescencia en cima de forma más o menos piramidal; inflorescencia cimosa o subcorimbosa; semillas 12-16 mm de largo ............. 1. F. myriantha

1. Sépalos 2,5-4,1 mm de largo; inflorescencia tirsiforme, pero de apariencia espiciforme; semillas 8,5-10 mm de largo........

2. F. spicata

1. Forsteronia myriantha Donn. Sm., Bot. Gaz. 27(6): 435. 1899

Tipo: Guatemala. Zacatepequez: Embaulada, XII.1889, E. Heyde E E. Lux 4534 (lectótipo, designado por Hansen \& Morales (2009), US [3 pliegos]; isolectótipos, BM, G, GH, K, M, US). (Fig. 13 D).

Liana, tallos puberulentos a glabrescentes o glabros. Hojas con láminas 4-11,3 × 2,7-4,7 cm, elípticas, el ápice acuminado, la base redondeada a subcorda$\mathrm{da}$, glabras, a veces inconspicuamente puberulentas por el envés, pecíolo 1,5-7 mm de largo. Inflorescencia cimosa, puberulenta, pedicelos 1-2 $\mathrm{mm}$ de largo, brácteas 1-3 mm de largo; sépalos ca. $1 \mathrm{~mm}$ de largo, ovados; corola verde o crema, glabra o puberulenta en la superficie externa, tubo menos de $1 \mathrm{~mm}$ de largo, lóbulos 2-3 × 1-1,5 mm, angostamente ovados; anteras ca. $2 \mathrm{~mm}$ de largo, exsertas, nectario pentalobulado. Folículos 27,9-42,8 × 0,3-0,5 cm, glabros o puberulentos, continuos; semillas $12-16 \mathrm{~mm}$ de largo, coma 2,1-2,5 cm de largo.

Distribución. México a Panamá, Colombia, Ecuador, Perú y Bolivia. Bosques muy húmedos, bajo los $600 \mathrm{~m}$ de elevación. Especímenes con flores fueron recolectados en marzo.

Esta especie aparentemente es bastante rara en Honduras, donde se puede reconocer por sus hojas de apariencia glabra, inflorescencias cimosas y abiertas, y sépalos de ca. $1 \mathrm{~mm}$ de largo.

Espécimen representativo examinado. HONDURAS. Cortés: Balincito, al S de lago de Yojoa, 26.III.1983 (fl), Nelson E Escobar 8596 (MO, TEFH).

2. Forsteronia spicata (Jacq.) G. Mey., Prim. Fl. Esseq. 135.1818

Echites spicatus Jacq., Enum. Syst. Pl. 13. 1760

Tipo: Colombia. Lectótipo, designado por Hansen (1985), Jacquin, Sel. Stirp. Amer. Hist. 2: pl. 29. 1763. (Fig. 3 B, 14 A,B). 
Liana, tallos puberulentos o glabrescentes. Hojas con láminas 5,8-15,3 × 3-7,8 cm, elípticas, a angostamente obovadas, el ápice caudado-acuminado, la base redondeada, glabrescentes o esparcidamente puberulentas por el haz, puberulentas por el envés, con mechones de pelos en las axilas de los nervios, pecíolo 4$9 \mathrm{~mm}$ de largo. Inflorescencia tirsoide, pero de apariencia espiciforme, puberulenta, las flores (sub)sésiles, brácteas 1,5-5 mm de largo; sépalos 2,5-4,1 mm, ovados; corola verde(-crema), glabra o glabrescente en la superficie externa, tubo ca. $2 \mathrm{~mm}$ de largo, lóbulos 3-4 $\times 1,5-2 \mathrm{~mm}$, angostamente ovados; anteras ca. 2 $\mathrm{mm}$ de largo, exertas, nectario pentalobulado. Folículos $15-22,1 \times 0,6-0,7 \mathrm{~cm}$, fusionados o libres, glabrescentes o puberulentos; semillas 8,5-10 mm de largo, coma 2,5-4,2 cm de largo.

Distribución. México a Colombia y Cuba. Bosques secos, en elevaciones de 100-700 m. Especímenes con flores han sido recolectados entre mayo y julio.

Nombres comunes. "Cacho de Chivo" (El Paraíso).

Forsteronia spicata es relativamente común en bosques secos o ecosistemas relacionados y se reconoce con facilidad por sus hojas con la superficie abaxial pubescente, con mechones de pelos en las axilas a lo largo del nervio central e inflorescencia de apariencia espiciforme.

Especímenes representativos examinados. HONDURAS. Choluteca: cercanías de Pespire, 18-27.X.1950 (fr), Standley 27139 (EAP). Comayagua: río Selguapa, por El Taladro, al W de Comayagua, 25.V.1982 (fl), Holst 1129 (EAP). El Paraíso: Vado Ancho, Tolobre, al SSE de San Lucas, entre El Zamorano y Morolica, 16.VI.1994 (fl), Davidse E al. 35038 (EAP, MO). Francisco Morazán: río Yeguare, 16.VII.1948 (fl), Glassman 2194 (EAP). La Paz: río Humuya, al E de la Paz, 2.VII.1974 (fl), Hazlett 1696 (MO, TEFH). Olancho: cercanías de Juticalpa, 5-16.III.1949 (fr), Standley 18141 (EAP).

12. Lacmellea H. Karst., Linnaea 28: 449. 1856 [1857]

Árboles, arbustos o hierbas semiarbustivas, tallos con secreción lechosa, glabros a puberulentos, el tronco con o sin aguijones, coléteres interpeciolares ausentes. Hojas opuestas, eglandulares, láminas labras a puberulentas, pecioladas. Inflorescencias cimosas, axilares, con pocas a muchas flores, brácteas escamiformes; cáliz con 5 sépalos, similares, inconspicuos, sin coléteres en la base; corola hipocraterimorfa, sin corona anular o lóbulos coronales libres, crema, blanca o amarillenta, limbo con 5 lóbulos, con estivación sinistrorsa; estambres incluidos, anteras no conniventes ni aglutinadas a la cabeza estigmática, cabeza estigmática cilíndrica o fusiforme; gineceo bicarpelar, sincárpico, nectario anular. Frutos en bayas sincárpicas, comestibles; semillas 1-4, desnudas.
Género con cerca de 24 especies, distribuidas desde Guatemala hasta Brasil y Bolivia, una sola conocida en Honduras (Monachino, 1944; Morales, 1998a).

1. Lacmellea standleyi (Woodson) Monach., Lloydia 7(4): 285. 1944 [1945]

Zschokkea standleyi Woodson, Publ. Field Mus. Nat.

Hist., Bot. Ser. 22(1): 44.1940

Tipo: Guatemala. Izabal: Entre Ríos, 30.IV.1939 (fl), P. Standley 72587 (holótipo, MO; isótipo, F [foto F neg 58610]). (Fig. 14 C).

Árboles de 5-12 m de altura, el tronco usualmente con aguijones. Hojas con láminas 8,3-14,9 × 2,6-4,8 $\mathrm{cm}$, elípticas, el ápice cortamente acuminado, la base obtusa o redondeada, glabras, pecíolo $6-10 \mathrm{~mm}$ de largo. Inflorescencia con 4-10 flores, pedicelos 3-7 $\mathrm{mm}$ de largo, brácteas de ca. 1,5 mm de largo; sépalos de 1,5-2 × 2,5-3 mm; corola blanca a crema, glabra, tubo 20-25 × 2,5-3 mm; lóbulos 9-13 × 2-3,5 mm, angostamente ovados; anteras 4,5-5,5 mm de largo. Frutos suborbiculares, $1,5-2,5 \mathrm{~cm}$ de largo, amarillos al madurar.

Distribución. Guatemala, Honduras y Belice. Bosques muy húmedos, bajo los $500 \mathrm{~m}$. Flores y frutos se han registrado en mayo.

Nombres comunes. "Palo de vaca" (Nelson, 2008).

Lacmellea standleyi se puede reconocer por su hábito arbóreo, con el tronco usualmente con aguijones, hojas opuestas, inflorescencias axilares y cimosas con pocas flores y frutos abayados, de color amarillo o anaranjado al madurar. Tanto los frutos como las flores y savia de esta especie son comestibles (como en las demás especies del género). Lacmellea panamensis ha sido un nombre mal aplicado para este taxón, especie que de otro modo se conoce hasta el S de Nicaragua y de la que $L$. standleyi difiere por sus flores con el cáliz mucho más grande y desarrollado.

Especímenes representativos examinados. HONDURAS. Atlántida: Pico Bonito, SW de La Ceiba, 14.V.1993 (fl, fr), Evans 1648 (MO). Yoro: SE del valle Lean, Placencia, 25.V.1978 (fl), Hazlett E Coe 2743 (EAP, INB, MO, U, USF, WAG).

\section{Macropharynx Rusby, Mem. New York Bot.} Gard. 7:327. 1927

Lianas, tallos con secreción acuosa o acuoso-lechosa, tomentulosos a híspidos, coléteres interpeciolares inconspicuos. Hojas opuestas, eglandulares, láminas glabrescentes a pubescentes, pecioladas. Inflorescencias cimosas, axilares, con pocas a numerosas flores, brácteas foliáceas a subfoliáceas, pedicelos con numerosas bractéolas, algunas veces rodeando el cáliz en su parte basal y de la misma longitud de los sépalos; cáliz 
con 5 sépalos, similares, foliáceos, con un coléter solitario en la base; corola infundibuliforme a hipocraterimorfa, sin corona anular, con cinco lóbulos coronales libres, blancas, blanco-verdosas a cremas o amarillo pálido, limbo con 5 lóbulos, con estivación dextrorsa; estambres incluidos, anteras conniventes y aglutinadas a la cabeza estigmática, cabeza estigmática con un anillo basal; gineceo bicarpelar, apocárpico, nectarios separados o levemente fusionados en la base y formando un nectario pentalobulado. Frutos folículos apocárpicos, lisos, continuos, algo leñosos; semillas numerosas, secas, rostradas y comosas en el ápice micropilar.

Género con 5 especies distribuido en forma disyunta en Honduras, Costa Rica y de Colombia a Brasil, Bolivia y Argentina, con sólo una presente en Honduras (Morales, 1997c). La presencia de lóbulos coronales en el género no había sido reportada anteriormente.

1. Macropharynx renteriae A.H. Gentry, Phytologia 47: 99. 1980

Tipo: Colombia. Chocó: ca. 37 [km?] O de Las Animas, carretera Panaméricana, 10.I.1979 (fl), A. Gentry \& E. Renteria 23955 (holótipo, COL; isótipos, HUA, INB, MO, NY). (Fig. 14 D).

Liana, ramitas y hojas tiernas ferrugíneo-tomentulosas. Hojas con láminas 11-28,9 × 7,4-19,9 cm, anchamente elípticas a ovadas, el ápice caudado-acuminado, la base obtusa o subcordada, glabras o glabrescentes en el haz, ferrugíneo-tomentulosas en el envés, puberulentas con la edad, pecíolo 3,3-8 cm de largo. Inflorescencia ferrugíneo-puberulenta, pedicelos 9$18 \mathrm{~mm}$ de largo, brácteolas $10-20 \mathrm{~mm}$, foliáceas; sépalos 1,2-2 cm, angostamente elípticos; corola infundibuliforme, blanca con la garganta amarilla, parte inferior del tubo 0,7-1,2 cm de largo, ca. $2 \mathrm{~mm}$ de largo, parte superior 1-1,2 cm de largo, ca. $4 \mathrm{~mm}$ en la fauce, lóbulos 2-2,3 × 1,8-2,3 cm, obovados; anteras 7-8 mm de largo, nectarios sobrepasando al ovario. Folículos 40-43 × 0,8-1 cm, ferrugíneo-tomentulosos; semillas 7-9 mm de largo, coma 3,4-4,6 cm de largo.

Distribución. Honduras, Costa Rica, Colombia y Ecuador. Bosques muy húmedos, en elevaciones de 100-250 m. Flores se han registrado en mayo.

Este género se registra por primera vez para Honduras, ya que anteriormente se conocía hasta el $\mathrm{N}$ de Costa Rica (Morales, 1997c, 2005a). Macropharynx renteriae se reconoce por el indumento ferrugíneo presente en los tallos y hojas jóvenes, así como la presencia de numerosas bractéolas (en adición a las brácteas florales) en las inflorescencias, corolas con cinco lóbulos coronales variadamente lacerados y en forma opuesta a cada antera y por la longitud y grosor de los folículos.
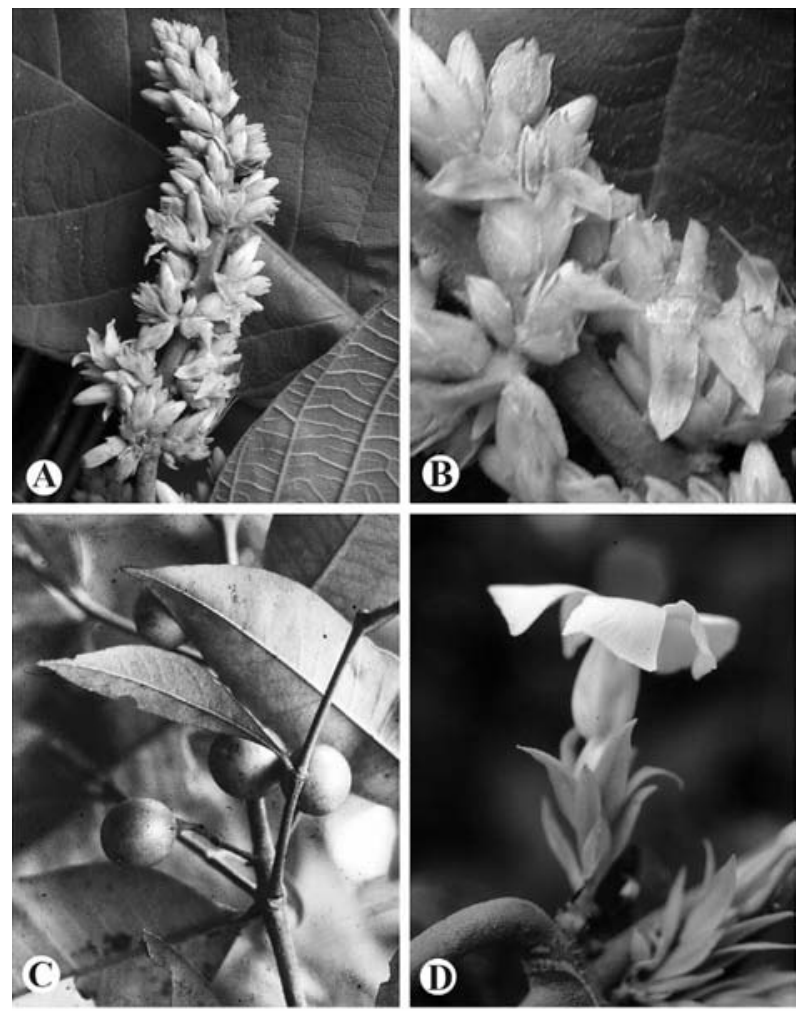

Fig. 14. Forsteronia, Lacmellea y Macropharynx. A,B, Forsteronia spicata; C, Lacmellea standleyi; D. Macropharynx renteriae.

Espécimen representativo examinado. HONDURAS. Atlántida: falda N de Pico Bonito, al SW de La Ceiba, 14.V.1993 (fl), Evans 1649 (EAP, INB, MO).

\section{Malouetia A. DC., Prodr. 8: 378. 1844}

Árboles o arbustos, tallos con secreción lechosa, glabros a puberulentos, sin espinas o aguijones, coléteres interpeciolares inconspicuos. Hojas opuestas, eglandulares, láminas glabras a puberulentas, generalmente con domacios a lo largo del nervio central, pecioladas. Inflorescencias cimas umbeliformes o fasciculadas, terminales o axilares, con pocas o muchas flores, brácteas escamiformes; cáliz con 5 sépalos, similares, diminutos, con coléteres en la base; corola hipocraterimorfa, sin corona anular, el orificio calloso y engrosado por la presencia de 10 escamas coronales callosas, blanca o crema, algunas veces matizadas con rosado o rojizo, limbo con 5 lóbulos, con estivación dextrorsa; estambres incluidos o las anteras exertas, conniventes y aglutinadas a la cabeza estigmática, cabeza estigmática fusiforme y subcapitada; gineceo bicarpelar, apocárpico, nectario pentalobulado o separado en 5 nectarios. Frutos folículos apocárpicos, lisos, continuos y levemente leñosos; semillas numerosas, secas, no comosas. 
Género con ca. 27 especies, mayormente en el Neotrópico (Guatemala a Brasil y Perú) y en los trópicos del W y centro de África, sólo una conocida en Honduras (Woodson, 1935).

1. Malouetia guatemalensis (Müll. Arg.) Standl., J. Wash. Acad. Sci. 15(20): 459. 1925

Stemmadenia guatemalensis Müll. Arg., Linnaea 30: 410. 1860

Tipo: Guatemala. Departamento desconocido: "Mniogalpa", 1841 (fl), Friedrichsthal 982 (holótipo, W; isótipo, NY). (Fig. 15 A).

Árboles 2,5-9 m de altura. Hojas con láminas 7,3$22,5 \times 2,4-8,2 \mathrm{~cm}$, elípticas, el ápice acuminado, la base obtusa, glabras, pecíolo 4-10 mm de largo. Inflorescencia con numerosas flores, pedicelos 3-6 mm de largo, brácteas ca. $1 \mathrm{~mm}$ de largo; sépalos 1,5-2 mm de largo, angostamente ovados; corola blanca o crema, tubo 4-5 mm de largo, ca. 1,5 mm de diámetro en la fauce, lóbulos 5-9 × 1,5-2 mm, angostamente elípticos, puberulentos en la base; estambres insertos, anteras ca. $2 \mathrm{~mm}$ de largo, nectarios más cortos que el ovario. Folículos 9,3-12,5 × 1,3-1,5 cm, divaricados, glabros; semillas ca. $2 \mathrm{~cm}$ de largo, glabras.

Distribución. Guatemala a Colombia. Bosques muy húmedos, márgenes de zonas anegadas en elevaciones de 0-200 m. Especímenes con flores se han recolectado entre enero y agosto. Frutos se registran en marzo y agosto.

Nombres comunes. "Cojón de burro", "Cojón de Mico", "Huele de Noche", "Lechón", "Lechón Negro" (Atlántida). Adicionalmente, Nelson (2008) reporta los siguientes nombres: "Barquito"; "Buntun" (mískito); "Oreja de Chancho"; "Orejuel".

Malouetia guatemalensis se reconoce por su hábito arborescente, inflorescencias axilares, fasciculadas y frutos foliculares, divaricados y fusiformes, con las semillas careciendo de comas apicales. Esta especie puede llegar a ser común en márgenes de zonas anegadas o lagunas.

Especímenes representativos examinados. HONDURAS. Atlántida: Tela, río Piedras Gordas, 15.VIII.1981 (fr), Nelson 7775 (MO, TEFH). Colón: Trujillo, orilla del río Negro, 12.III.1983 (fr), Nelson 8551 (MO, TEFH). Gracias a Dios: Barra de Brus Laguna, 24-31.I.1976 (fl), Vargas E al. 375 (MO, TEFH).

15. Mandevilla Lindl., Edwards's Bot. Reg. 26: t. 7. 1840, nom. cons.

Lianas, hierbas erectas, suberectas o escandentes, raramente arbustos o árboles pequeños, tallos con secreción lechosa o acuosa, glabros o pubescentes, sin espinas o aguijones, coléteres interpeciolares inconspicuos a conspicuos y muy desarrollados, simulando pequeñas garras. Hojas opuestas a verticiladas, con coléteres en la base del nervio central o distribuidas a lo largo del mismo, raramente eglandulares, láminas glabras a pubescentes, a veces con domacios, sésiles a pecioladas. Inflorescencias racemosas, axilares a subterminales o terminales, con pocas a numerosas flores, brácteas escamiformes a foliáceas; cáliz con 5 sépalos, similares, diminutos a foliáceos, con coléteres solitarios en la base o distribuidas en líneas; corola infundibuliforme o hipocraterimorfa, sin corona anular o lóbulos coronales libres, de colores variados, limbo con 5 lóbulos, con estivación dextrorsa; estambres incluidos, anteras conniventes y aglutinadas a la cabeza estigmática, cabeza estigmática con cinco proyecciones o costillas longitudinales o ubicadas en su parte basal; gineceo bicarpelar, apocárpico, nectarios 2-5, separados o unidos en la base y formando un nectario pentalobulado o lobulado. Frutos folículos apocárpicos, continuos o moniliformes, membranáceos, raramente algo leñosos; semillas numerosas, secas, truncadas y comosas en el ápice micropilar.

Género con ca. 170 especies distribuidas desde México y las Antillas hasta Argentina, 4 registradas para Honduras (Morales 1998b; 2005a; Simões et al., 2004, 2006, 2007b).

1. Coléteres distribuidos a lo largo del nervio central; tubo giboso en la base ......................................................... 2

1. Coléteres agrupados en la base del nervio central; tubo de la corola recto, no giboso ............................................... 3

2. Corola infundibuliforme, el tubo $33-55 \mathrm{~mm}$ de largo; sépalos 5-12 mm de largo; brácteas 6-22 mm de largo, foliáceas .....

2. M. hirsuta

2. Corola hipocraterimorfa, el tubo $20-33 \mathrm{~mm}$ de largo; sépalos 2,5-3,5 mm de largo; brácteas 2-5 mm de largo, no foliáceas

3. M. subsagittata

3. Estambres insertos ca. en la mitad de la longitud total del tubo de la corola; ápice de los botones florales acuminados.

1. M. acutiloba

3. Estambres insertos justo por debajo de la fauce; ápice de los botones florales agudos

4. M. tubiflora

1. Mandevilla acutiloba (A. DC.) Woodson, Ann. Missouri Bot. Gard. 19(1): 54. 1932

Echites acutilobus A. DC., Prodr. 8: 451. 1844

Amblyanthera acutiloba (A. DC.) Müll. Arg., Linnaea 30: 426. 1860

Tipo: México. Datos perdidos (fl), Pavon s.n. (holótipo, G-DC [foto F neg 34138]). (Fig. 15 B).

Echites rosanus Donn. Sm., Bot. Gaz. 40(1): 6. 1905 Mandevilla rosana (Donn. Sm.) Woodson, Ann. Missouri Bot. Gard. 19(1): 56. 1932

Tipo: Guatemala. Santa Rosa: Buena Vista, IV.1893 (fl), Heyde E Lux 4540 (holótipo, US [foto, INB]; isótipos, B [destruido], GH, K). 
Mandevilla scorpioidea Woodson, Ann. Missouri Bot. Gard. 19(1): 56-57. 1932

Tipo: México. Chiapas: Cerro de Boquerón, VI.1914 (fl), Purpus 7274 (holótipo, MO; isótipos, BM, F [foto F neg 56478], GH, NY, US).

Mandevilla contrerasii Lundell, Wrightia 5(7): 257 258. 1976

Tipo: Guatemala. Baja Verapaz: Unión Barrios, 16.VI.1975 (fl), Lundell \& Contreras 19461 (holótipo, LL; isótipos, F [foto F neg 61420], MO, S).

Liana, tallos hispídulos, puberulentos con la edad. Hojas con láminas 3,9-13,8 × 2,4-5,1 cm, ovadas a elípticas, el ápice acuminado, la base cordada, los coléteres agrupados en la base del nervio central, hispidulosas en el haz, tomentulosas por el envés, raramente glabrescentes, pecíolos 3,5-13 mm de largo. Inflorescencia hirsútula, pedicelos 6-13 mm de largo, brácteas 3,5$8 \mathrm{~mm}$ de largo, diminutas, no foliáceas; sépalos 4-6,3 $\mathrm{mm}$ de largo, angostamente ovados; corola hipocraterimorfa, verde-crema o amarillenta, glabra, tubo 14-18 $\times 1-2,5 \mathrm{~mm}$, recto, no giboso; lóbulos 4-6 × 2-3 mm, angostamente ovados; estambres insertos ca. en la mitad de la longitud total del tubo, anteras ca. 4,5 mm de largo, nectario pentalobulado, tan largo como el ovario o ligeramente más corto. Folículos $18-25 \mathrm{~cm} \times 1,2$ $3 \mathrm{~mm}$, glabros, continuos a torulosos; semillas 8-9 mm de largo, coma 1,5-2,5 cm de largo.

Distribución. S de México, Guatemala y Honduras. Formaciones de bosques de pino-encino y vegetación secundaria entre 1000-1800 m. Material con flores ha sido recolectado entre julio y agosto.

Esta especie ha sido tradicionalmente confundida con Mandevilla tubiflora, pero ambas se pueden separar con facilidad por los caracteres dados en la clave. El ápice de los botones florales es un carácter que ha sido pasado por alto a través de distintos tratamientos florísticos y monográficos de este género, pero de hecho es de relativa utilidad para reconocer y separar algunas especies.

Especímenes representativos examinados. HONDURAS. Comayagua: El Rincón, W de Siguatepeque, 24.VII.1936 (fl), Yuncker E al. 6049 (K, MO, NY, US). Francisco Morazán: quebrada de Suyapa, 19.VIII.1950 (fl), Standley 26475 (EAP, US).

2. Mandevilla hirsuta (Rich.) K. Schum., Nat. Pflanzenfam. 4(2): 171. 1895

Echites hirsutus Rich., Actes Soc. Hist. Nat. Paris 1: 107. 1792

Amblyanthera hirsuta (Rich) Miers, Apocyn. S. Am. 185. 1878

Tipo: Guyana Francesa. Sin localidad, 1792 (fl), M. Leblond 387 (lectótipo, designado por Allorge-Boi- teau, (1998), P-LA; isolectótipos, G-DC, P $[2$ pliegos, foto F neg. 26863]). (Fig. 3 C, 6 B, 15 C).

Liana, tallos pubescentes. Hojas con láminas 6,3$15,2 \times 2,6-7,8 \mathrm{~cm}$, elípticas a obovadas, el ápice acuminado, la base auriculada y cordada, con los coléteres distribuidos a lo largo del nervio central, pubescentes, pecíolo 10-45 mm de largo. Inflorescencias pubescentes, pedicelos 4-10 mm de largo, brácteas 6$22 \mathrm{~mm}$ de largo, foliáceas; sépalos 5-12 mm de largo de forma variada, foliáceos; corola infundibuliforme, amarilla, con el interior del tubo rojizo, pubescente, parte inferior del tubo 19-31 mm de largo, parte superior 14-22 mm de largo, cónica, 12-18 mm de diámetro en la fauce, lóbulos 16-23 × 15-21 mm, obovados; estambres insertos en la base de la parte superior del tubo, anteras ca. $5 \mathrm{~mm}$ de largo, nectarios más pequeños que el ovario. Folículos 9,5-19,5 × 0,3-0,5 cm, moniliformes, pubescentes; semillas $9-12 \mathrm{~mm}$ de largo, coma 1,8-2,4 cm de largo.

Distribución. S de México a Brasil, Bolivia y Paraguay. Bosques muy húmedos, en elevaciones de 0 $1300 \mathrm{~m}$. Especímenes con flores y frutos se han recolectado de manera irregular durante todo el año.

Nombres comunes. "Bejuco de culebra" (Nelson, 2008).

Mandevilla birsuta, la especie más ampliamente distribuida del género, es a su vez una de las más variables en cuanto a la densidad y tipo de indumento. A través de los años, numerosos táxones a nivel específico y varietal han sido descritos, pero corresponden a rangos extremos sin ninguna discontinuidad que justifiquen su aceptación. En Honduras, se puede separar con facilidad del resto de especies, por la longitud total del tubo de la corola $(33-58 \mathrm{~mm})$, así como las brácteas foliáceas de la inflorescencia. La sinonimia completa puede ser consultada en Morales (2007).

Especímenes representativos examinados. HONDURAS. Atlántida: Esparta, E de Tela, 11.IV.1994 (fl), Brant E Zúñiga 2818 (INB, MO). Cortés: montaña La Cumbre, Las Piñitas, 21.III.1962 (fl), Molina 10586 (EAP, US). Gracias a Dios: río Rus-Rus, VII.1977 (fl), Nelson E al. 4180 (MO, UNAH). Yoro: Loma Larga pine ridge, 25.IV.1995 (fl), Hawkins E al. 836 (INB, MO)

3. Mandevilla subsagittata (Ruiz \& Pav.) Woodson, Ann. Missouri Bot. Gard. 19: 69. 1932

Echites subsagittatus Ruiz \& Pav., Fl. Peruv. Prodr. 2: 19. 1799

Tipo: Perú: Sin datos, (fl), H. Ruiz \& H. Pavón 11/56 (holótipo, MA; isótipo, $F$ [foto F neg. 29216]). (Fig. 15 D).

Echites cuspidifer S.F. Blake, Contr. Gray Herb. 52: 79. 1917 

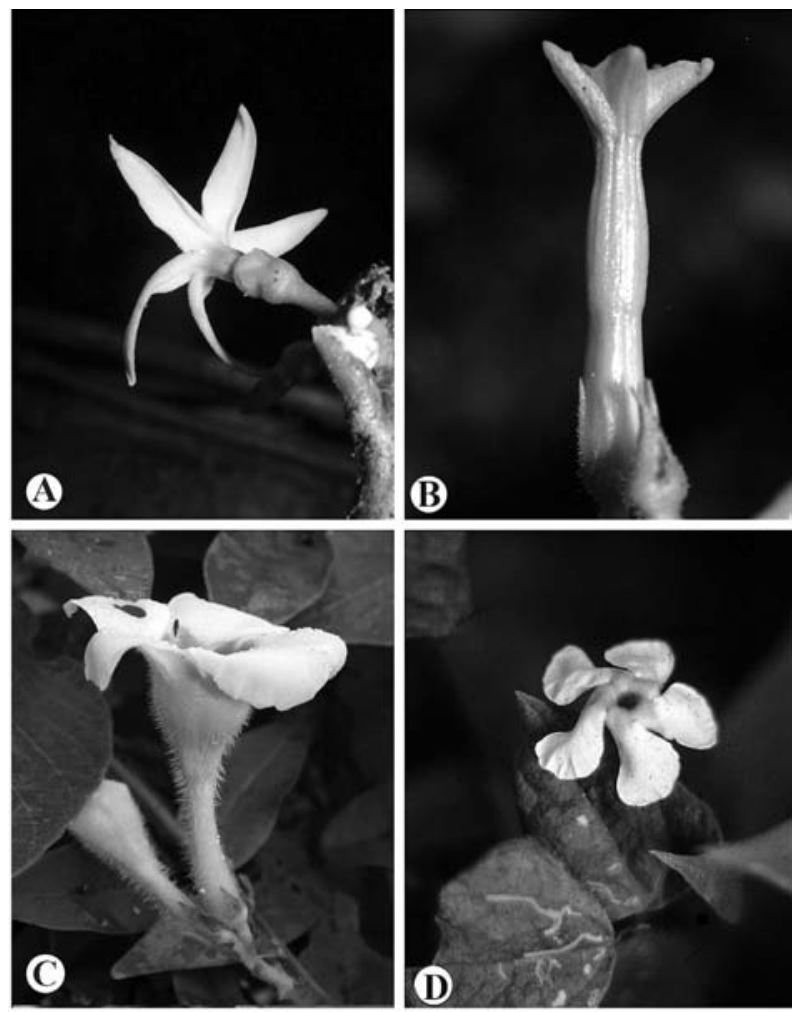

Fig. 15. Malouetia y Mandevilla. A, Malouetia guatemalensis; B, Mandevilla acutiloba; C, M. hirsuta; D, M. subsagittata.

Tipo: Belice. Cayo: Pine ridge, 11.VI.1905 (fl), M. Peck 35 (holótipo, GH; isótipo, K).

Lianas, tallos glabros a pubescentes. Hojas 3,3-8,5 $\times 1,2-3,8 \mathrm{~cm}$, elípticas, el ápice agudo a cortamente acuminado, la base auriculada, con los coléteres a lo largo del nervio central, glabras a puberulentas en el haz, pecíolo 3-10 mm de largo. Inflorescencia glabrescente a glabra, pedicelos 4-8 $\mathrm{mm}$ de largo, brácteas 2 $5 \mathrm{~mm}$ de largo, diminutas; sépalos 2,5-3,5 mm de largo, ovados; corola hipocraterimorfa, amarilla con la base de los lóbulos y la fauce del tubo rojo, glabra o pubescente por el exterior, tubo 2-3,3 cm de largo, giboso, lóbulos 10-16 × 8-15 mm, obovados; estambres insertos cerca de la fauce del tubo, anteras $4-5 \mathrm{~mm}$ de largo, nectario pentalobulado. Folículos 9,9-21,3 $\times$ $0,2-0,3 \mathrm{~cm}$, moniliformes, glabros; semillas $6-8 \mathrm{~mm}$ de largo, coma 1,8-2,2 cm de largo.

Distribución. México hasta Colombia, Venezuela, Ecuador y Perú. Bosques secos y bosques húmedos, en elevaciones de 0-1500 m. Floración y fructificación se producen de forma irregular durante todo el año.

Nombres comunes. "Flor de mico" (Nelson, 2008).

Mandevilla subsagittata se puede reconocer fácilmente en Honduras por la siguiente combinación de caracteres: hojas con los coléteres distribuidos a lo largo del nervio central, brácteas florales diminutas, no foliáceas, corolas hipocraterimorfas amarillas y folículos moniliformes. Esta especie sólo se puede confundir con M. villosa (Miers) Kuntze (aún no registrada en Honduras, pero que es de esperar), de la que se separa al instante por sus brácteas florales diminutas (vs. foliáceas).

Especímenes representativos examinados. HONDURAS. Colón: NE de Trujillo, camino a Castilla, 19.VI.1980 (fl), Saunders 396 (MO, TEX). Comayagua: cercanías de Siguatepue, 7.I.1936 (fl), Yuncker E al. 5548 (K, MO, NY). Copán: NE de Cucuyagua, camino a Santa Rosa, 26.VI.1994 (fl), Davidse E al. 35380 (INB, MO). Cortés: N de Lago de Yajoa, XI.1980 (fl), Nelson E al. 5607 (INB, MO, TEFH). El Paraíso: Guinope, a lo largo del río Leotuna, entre El Zamorano y Morolica, 16.VI.1994 (fl, fr), Davidse \& al. 34977 (INB, MO). Francisco Morazán: El Picacho, 12.VIII.1979 (fl), Bonilla 18 (HBG). Gracias a Dios: Ahuas, 12.XII.1972 (fl), Clewell 3632 (MO). Intibuca: Yamaranguilla, NW de La Esperanza, río Toco, 22.VI.1994 (fl), Davidse E al. 35249 (MO). Islas de la Bahía: Oak ridge, 30.III.1984 (fl), Nelson \& Cruz 8742 (MO). Ocotepeque: NW de Nuevo Ocotepeque, camino a Agua Caliente, 12.VI.1985 (fl), Martínez \& Tellez 13043 (MEXU, MO). Olancho: montaña Chifiringo, 6.X.1979 (fl), Lezama 124 (MO). Sánta Barbara: río Sisicapa, 12.XII.1950 (fl, fr), Molina 3751 (EAP, US). Yoró: río Jalegua, N de El Yoro, 1974 (fr), Nelson E Martínez 1947 (MO).

4. Mandevilla tubiflora (M. Martens \& Galeotti) Woodson, Ann. Missouri Bot. Gard. 19(1): 52.1932 Echites tubiflorus M. Martens \& Galeotti, Bull. Acad. Roy. Sci. Bruxelles 11(1): 358. 1844

Amblyanthera tubiflora (M. Martens \& Galeotti)

Müll. Arg., Linnaea 30: 423. 1860

Tipo: México. Oaxaca: cerca de Xalapa, X.1841 (fl), Galeotti 1579 (holótipo, K [foto, INB]; isótipo, P).

Echites cobanensis Donn. Sm., Bot. Gaz. 40(1): 6. 1905

Tipo: Guatemala. Alta Verapaz: Cobán, VIII.1904 (fl), Tuerckheim 8709 (holótipo, US; isótipo, NY).

Mandevilla donnell-smithii Woodson, Ann. Missouri Bot. Gard. 19(1): 54-55. 1932

Tipo: Guatemala. Santa Rosa: Cerro Gordo, VIII.1892 (fl), Heyde E Lux 3993 (holótipo, GH; isótipos, K [foto, INB], NY, US).

Lianas; tallos hirsútulos, glabrescentes. Hojas con láminas 2,9-10,2 × 0,9-4,8 cm, elípticas a ovadas, el ápice cortamente acuminado, la base cordada, obtusa a redondeada, los coléteres agrupados en la base del nervio central, esparcidamente puberulentas a glabrescentes en el haz, densamente tomentosas o glabrescentes en el envés, pecíolos 6-24 mm de largo. Inflorescencia hirsutula, pedicelos $5-11 \mathrm{~mm}$ de largo, brácteas 1,3-4 mm de largo, diminutas; sépalos 2,1-3 $\mathrm{mm}$ de largo, ovados; corola hipocraterimorfa, amarilla o crema, glabra, el tubo $12-17 \times 1,7-3 \mathrm{~mm}$, no gi- 
boso; lóbulos 2,5-5 × 2-3,5 mm, angostamente ovados; estambres insertos justo debajo de la fauce, anteras 2,9-3,5 mm de largo; nectarios tan largos como o ligeramente más cortos que el ovario. Folículos 15-17,3 $\mathrm{cm} \times 1,3-2,8 \mathrm{~mm}$, glabros, continuos o torulosos; semillas 8-9 mm de largo, coma 1,3-2,7 cm de largo.

Distribución. México, Guatemala, Honduras, El Salvador y el $\mathrm{N}$ de Nicaragua. Bosques secos y formaciones de pino-encino entre 1100-2000 m. Especímenes con flores han sido recolectados entre marzo y diciembre.

Mandevilla tubiflora se ha confundido con M. acutiloba, pero difiere por sus estambres insertos en la mitad distal del tubo de la corola, con los ápices de las anteras ligeramente por debajo de la fauce del tubo, así como por sus botones florales con el ápice agudo. $\mathrm{El}$ indumento de la superficie abaxial de las hojas de esta especie es muy variable.

Especimenes representativos examinados. HONDURAS. Comayagua: Barranco El Socorro, carretera Siguatepeque-Comayagua, 28.XI.1958 (fl), Hawkes et al. 2112 (EAP, K). El Paraíso: quebrada Tapahuasca, 14.VIII.1964 (fl), Molina 14629 (EAP, F, US). Francisco Morazán: Monte Oscuro, Cordillera Azacualpa, 14.VII.1964 (fl), Molina 14538 (EAP, F, US). Lempira: La Campa, al SW de La Campa, 6.VIII.1997 (fl), McLaughlin 7239 (EAP).

\section{Mesechites Müll. Arg., Fl. Bras. 6(1): 150. 1860}

Lianas, tallos con secreción lechosa, glabros o diminutamente puberulentos, sin espinas o aguijones, coléteres interpeciolares inconspicuos a conspicuos y semejando pequeñas garras. Hojas opuestas, con 1-3 coléteres en la base de la vena central, glabras a puberulentas, pecioladas. Inflorescencia cimosa, axilar, con pocas a muchas flores, brácteas inconspicuas; cáliz con 5 sépalos, similares, diminutos, con varios coléteres en la base; corola hipocraterimorfa, verde, rosada, verde-rojiza, verde-crema o crema, sin corona anular o lóbulos coronales libres, limbo con 5 lóbulos, con estivación dextrorsa; estambres incluidos, anteras conniventes y aglutinadas a la cabeza estigmática, cabeza estigmática con cinco proyecciones o costillas longitudinales basales; gineceo bicarpelar, apocárpico, nectarios 5 , distintos o connados en la base y formando un nectario pentalobulado. Frutos folículos apocárpicos, lisos y continuos, membranáceos; semillas numerosas, secas, truncadas y comosas en el ápice micropilar.

Género con 10 especies distribuidas desde México y las Antillas a Bolivia y Argentina (excepto Uruguay y Chile), con una conocida en Honduras (Morales, 2006b).

1. Mesechites trifidus (Jacq.) Müll. Arg., Fl. Bras. 6(1): 151.1860

Echites trifidus Jacq., Enum. Syst. Pl. 13. 1760
Tipo: Tab. 24 en Jacquin, Select. Stirp. Amer. Hist. 1763 (lectótipo, designado por Morales (2005a). (Figs. 6 A, 7 A, 16 A).

Liana, tallos glabros o raramente puberulentos. Hojas con láminas 5,1-10,9 × 2,3-5,8 cm elípticas, el ápice cortamente acuminado, la base obtusa a redondeada, con 1 a 3 coléteres en la base del nervio central, pecíolo de 7-19 mm de largo. Inflorescencia con pedicelos 4-11 mm de largo, brácteas ca. 1,5 mm de largo; sépalos 3-4 mm de largo, angostamente ovados; corola blanca o blanco-verdosa, moteada con lila, tubo 1,5-2,5 cm de largo, 2,5-3,5 mm de diámetro en la fauce, lóbulos 10-15 × 8-9 mm, obovados; anteras 4,5-5,5 $\mathrm{mm}$ de largo, nectarios tan largos como el ovario. Folículos 29-33 × ca. 0,2 cm; semillas 10-11 mm de largo, coma 30-35 mm de largo.

Distribución. México y las Antillas a Brasil, Bolivia, Paraguay y Argentina. Bosques muy húmedos a bosques secos, en elevaciones de 0-1200 m. Flores y frutos son producidos durante todo el año.

Nombres comunes. "Corrimiento" (Nelson, 2008).

Mesechites trifidus pertenece a la tribu Mesechiteae (sensu Endress \& Bruyns, 2000), grupo de géneros (e.g., Mandevilla, Tintinnabularia) que se reconoce por sus hojas con coléteres en la superficie adaxial del nervio central, ya sea en la base o distribuidos a lo largo, así como cabezas estigmáticas con costillas o crestas, distribuidas a todo lo largo o solo en su región basal. Mesechites difiere del resto de géneros por sus hojas sin domacios en la superficie adaxial, inflorescencias cimosas, ramificadas y corolas hipocraterimorfas.

Especímenes representativos examinados. HONDURAS. Atlántida: cerro Cangrejal, cercanías de La Ceiba, 5.VII.1938 (fl), Yuncker E al. 8222 (BM, G, MO, NY, US). Colón: Laguna Guiamoreto, NE de Trujillo, 8.VII.1980 (fl), Saunders 448 (MO). Comayagua: Agua Caliente, vaguada de ríos Chamo y Humuya, 22.XI/31.XII.1980 (fl), Nelson et al. 6446 (INB, MO, TEFH). Copán: río Copán, cercanías de las ruinas de Copán, 18.XI.1969 (fl), Molina E Molina 24595 (EAP). Cortés: Cuyamel, 30.XII.1922 (fr), Carleton 424 (US). El Paraíso: cerca Galeras, 25.X.1951 (fl), Standley 29075 (EAP). Gracias a Dios: Ahuas Bila, al SW de Puerto Lempira, río Wankí, 5-13.V.1985 (fl), Nelson E Cruz 9148 (TEFH), Nelson E Cruz 9164 (TEFH). Intibucá: Agua Caliente, Las Marías, camino a Magdalena, 12.I.1975 (fr), Martínez 433 (TEFH). La Paz: al S de La Paz, río Humuya, por la Cañada, 28.IV.1983 (fl, fr), Holst 1065 (EAP). Francisco Morazán: río Jalán, N de Guaimaca, 13.VI.1950 (fl, fr), Molina 3087 (EAP, US). Olancho: La Unión, carretera a Olanchito, 1.VII.1994 (fl), Davidse E al. 35449 (EAP). Yoro: Pijol, Subirana, X.1937 (fl), Hagen E Hagen 1120 (NY).

\section{Nerium L., Sp. Pl. 1: 209. 1753}

Arbustos o árboles pequeños, tallos con secreción lechosa o acuoso-lechosa, glabros a puberulentos, sin espinas o aguijones, coléteres interpeciolares incons- 
picuos. Hojas verticiladas, raramente opuestas, eglandulares, láminas puberulentas a glabras, pecioladas. Inflorescencias en panículas tirsoides, terminales, con muchas flores, brácteas inconspicuas; cáliz con 5 sépalos, iguales, similares, con una línea de coléteres en la base; corola infundibuliforme, de variados colores, a veces con dobles o triples series de lóbulos, corona anular ausente, la garganta con 5 lóbulos coronales, petaloides, limbo con 5 lóbulos, con estivación dextrorsa; estambres incluidos o el ápice levemente exserto, anteras conniventes y aglutinadas a la cabeza estigmática, cabeza estigmática fusiforme; gineceo bicarpelar, apocárpico, nectario ausente. Frutos dos folículos apocárpicos, continuos y rectos, algo leñosos al secar; semillas numerosas, secas, comosas en el ápice micropilar.

Género monotípico originario de Eurasia, pero ampliamente cultivado en todo el mundo (Pagen, 1987).

\section{Nerium oleander L., Sp. Pl. 1: 209. 1753}

Tipo: Creta, Palaestina, Syria, India, sin fecha (fl), Herb. Clifford 76, Nerium No. 1B (lectótipo, designado por Stearn (1978), BM). (Fig. 16 B).

Arbustos 1-4 m de altura, ramas puberulentas a glabrescentes. Hojas con láminas 10,5-24,9 × 1,1-2,5 cm, angostamente elípticas a linear elípticas, el ápice agudo o cortamente acuminado, la base cuneada, glabrescentes a puberulentas, pecíolo 4-11 mm de largo. Inflorescencia puberulenta, pedicelos 6-11 $\mathrm{mm}$ de largo, brácteas 3-5 mm de largo; sépalos 5-7 mm de largo, ovados; corola blanca, crema, rosada o roja, parte inferior del tubo 9-15 $\mathrm{mm}$ de largo, parte superior 910 mm de largo, cónica, 5-9 mm de diámetro en la fauce, lóbulos de 1,9-2,7 cm de largo, obovados; anteras ca. $3 \mathrm{~mm}$ de largo. Folículos 7-11,5 ×0,5 cm; semillas ca. $5 \mathrm{~mm}$ de largo, coma 1-1,9 cm de largo.

Distribución. Cultivada como ornamental en forma ocasional en casi todo el país, en elevaciones de 100$1500 \mathrm{~m}$. Flores se producen durante todo el año.

Nombres comunes. "Adelfo" (Francisco Morazán); "Narciso" (La Paz). Los siguientes nombres han sido registrados por Nelson (2008): "Astro de Italia", "Laurel"; "Laurel rosa"; "Oleander" (inglés), "Rosal de la mar del sur".

Nerium oleander se ha cultivado tradicionalmente como ornamental, debido al llamativo color de sus flores, el cual varía desde blanco hasta rojo o morado. Se puede reconocer con facilidad por sus hojas verticiladas, con la nervadura terciaria conspicua y evidente, así como por sus corolas con 5 lóbulos coronales, petaloides. Es muy probable que se encuentre cultiva- do en todo el país, aunque las colecciones de herbario no lo demuestren con certeza.

Especímenes representativos examinados. HONDURAS. Atlántida: Lancetilla, 25.IV.1982(fl), Cámbar 101 (MO). Colón: La Cubana, al N de Sonaguera, 5.VI.1996 (fl), Pastor 1099 (EAP). Comayagua: Las Mercedes, 1.III.1982 (fl), Sosa 217 (MO). El Paraíso: Trincheras, al S de El Paraíso, 12.IV.1996 (fl), Pastor 801 (EAP). Francisco Morazán: Tegucigalpa, alrededores de UNAH, 30.IV.1975 (fl), García 38 (TEFH). La Paz: caserío Sigamane, al E de Marcala, 2.IV.1988 (fl, fr), Ramos 328 (TEFH). Santa Bárbara: Trinidad, 13.X.1990 (fl), Sagastume 75 (EAP).

18. Odontadenia Benth., J. Bot. (Hooker) 3: 242. 1841

Lianas, tallos con secreción lechosa, glabros o pubescentes, coléteres interpeciolares inconspicuos o conspicuos y desarrollados. Hojas opuestas, raramente verticiladas, eglandulares, láminas glabras a pubescentes, pecioladas a sésiles. Inflorescencias cimosas, axilares, de forma más rara terminales o subterminales, con pocas a numerosas flores, brácteas inconspicuas; cáliz con 5 sépalos, similares o conspicuamente desiguales, escariosos a foliáceos, con varias coléteres en la base; corola infundibuliforme o hipocraterimor$\mathrm{fa}$, de colores variados, sin corona anular o lóbulos coronales libres, limbo con 5 lóbulos, con estivación dextrorsa; estambres incluidos, anteras conniventes y aglutinadas a la cabeza estigmática, cabeza estigmática fusiforme; gineceo bicarpelar, apocárpico, nectarios 5, separados o en la base connados y formando un nectario pentalobulado. Frutos en folículos apocárpicos, lisos, continuos, algo leñosos al secar; semillas numerosas, secas, truncadas y comosas en el ápice micropilar.

Género con 20 especies distribuidas desde México y las Antillas a Brasil y Bolivia; 2 conocidas en Honduras (Morales, 1999).

1. Sépalos de longitudes similares; tallos viejos lisos, no lenticelados 1. O. macrantha

1. Sépalos de longitudes diferentes; tallos viejos lenticelados ... 2. O. puncticulosa

1. Odontadenia macrantha (Roem. \& Schult.) Markgr., Fl. Suriname 4: 461. 1937

Echites macranthus Roem. \& Schult., Syst. Veg. 4: 795. 1819

Echites hoffmannseggianus Steud., Nomencl. Bot. ed. 2. 1: 539.1840 , nom. inval.

Odontadenia hoffmannseggiana (Steud.) Woodson ex Gleason \& A.C. Smith, Bull. Torrey Bot. Club 60: 392. 1933

Tipo: Brasil. Sin datos (fl), Sieber in Hoffmannsegg s.n. (holótipo, B-W 5162). (Fig. 16 C). 


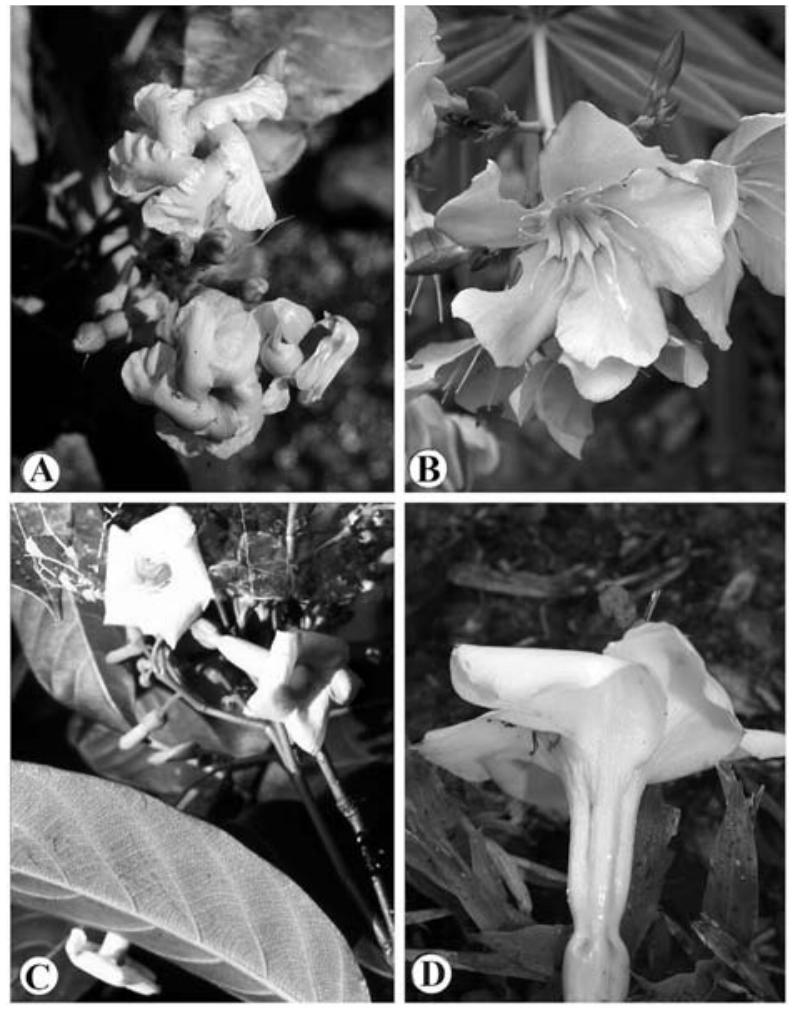

Fig. 16. Mesechites, Nerium y Odontadenia. A, Mesechites trifidus; B, Nerium oleander; C, Odontadenia puncticulosa; D, O. macrantha.

Odontadenia caudigera Woodson, Ann. Missouri Bot. Gard. 23(2): 384-386. 1936

Tipo: Belice: Sin datos, 1935 (fl), Schipp s.n. (holótipo, $\mathrm{MO}$ [fotocopia, INB]).

Lianas, tallos glabros, sin lenticelas, coléteres interpeciolares inconspicuos. Hojas con láminas 10,8-33,8 $\times 5,8-14,6 \mathrm{~cm}$, elípticas a obovadas, el ápice acuminado, la base obtusa, glabras, pecíolo 1,2-2,8 cm de largo. Inflorescencia glabra, pedicelos 1,2-2,5 cm de largo; sépalos 0,3-0,7 cm de largo, iguales, ovados; corola infundibuliforme, amarilla o anaranjada, la garganta rojiza, glabra, parte inferior del tubo $0,4-0,9 \mathrm{~cm}$ de largo, la parte superior 2,2-4 cm de largo, cónica, 0,9$1,5 \mathrm{~cm}$ en la fauce, lóbulos 2,3-4,2 × 1,2-2,4 cm, obovados; estambres insertos en la base de la parte superior del tubo, anteras $12-13 \mathrm{~mm}$ de largo, nectario 22,5 mm de largo, tan largo como el ovario o más largo. Folículos 20-26 cm de largo, fusiformes, glabros; semillas 3-4 cm de largo, coma 5,5-7 cm de largo.

Distribución. S de México y las Antillas a Brasil y Perú. Bosques muy húmedos, en elevaciones de 0-600 $\mathrm{m}$. Flores se registran entre enero y julio.

Nombres comunes. "Káuput" (Gracias a Dios, Ahuas Bila).
Odontadenia macrantha es la especie más común del género y en Honduras se puede reconocer con facilidad por sus tallos y hojas glabros, los primeros sin lenticelas, así como por el gran tamaño de sus frutos.

Especímenes representativos examinados. HONDURAS. Atlántida: valle de Lancetilla, cerca de Tela, 6.XII.1927/20.III.1928, Standley 54338 (F). Comayagua: río Jaitique, al S de Taulabe, 2.V.1974 (fl), Hazlett 1510 (EAP). Gracias a Dios: Camp Tiro, quebrada Tiro, tributario del río Plátano, 16.III.1981 (fl), Saunders 1082 (BM, F, INB, NY, TEFH).

2. Odontadenia puncticulosa (Rich.) Pulle, Enum. Vasc. Pl. Surinam 383. 1906

Echites puncticulosus Rich., Act. Soc. Hist. Nat. Paris 1: 107.1792

Tipo: Guyana Francesa: sin localidad, 1792 (fl), Leblond s.n. (lectótipo, designado por Allorge-Boiteau (1998), P-LA; isolectotipo, P). (Figs. 2 B, 16 D).

Odontadenia schippii Woodson, Ann. Missouri Bot. Gard. 22(2): 292-294. 1935

Tipo: Belice. Campamento 36, frontera Guatemala-Belice, 18.VI.1934 (fl), Schipp S-709 (holótipo, $\mathrm{MO}$; isótipos, BM [foto, INB], F, G, NY, Z).

Liana, tallos puberulentos a glabrescentes, lenticelados, coléteres interpeciolares subfoliáceos. Hojas con láminas 7,5-17,8 × 3,8-8,5 cm, elípticas a ovadas, el ápice acuminado, la base obtusa a redondeada, glabras o puberulentas, pecíolo $0,8-1,8 \mathrm{~cm}$ de largo. Inflorescencia puberulenta a glabrescente, pedicelos 0,9-2,5 cm de largo; sépalos 0,3-0,8 cm de largo, desiguales, angostamente ovados; corola infundibuliforme, amarilla o crema, puberulenta a glabra, parte inferior del tubo 1-1,6 cm de largo, la parte superior 2,33,6 cm de largo, cónica, 0,6-1 cm en la fauce, lóbulos 1,6-2,3 × 1,1-1,6 cm, obovados; estambres insertos en la base de la parte superior del tubo, anteras $5-6 \mathrm{~mm}$ de largo, nectario ca. $2 \mathrm{~mm}$ de largo, tan largo como el ovario. Folículos 12-17 cm de largo, divaricados a falcados, densamente puberulentos a glabrescentes; semillas 1,2-1,4 cm de largo, coma 4-6 de cm de largo.

Distribución. Honduras a Brasil y Bolivia. Bosques muy húmedos, en elevaciones de $0-450 \mathrm{~m}$. Floración se ha registrado en mayo y septiembre.

Odontadenia es un género principalmente sudamericano, con solo tres especies conocidas de Mesoamérica. En Honduras, O. puncticulosa se separa con facilidad por sus flores con los sépalos de longitudes diferentes, tallos viejos conspicuamente lenticelados y folículos divaricados o algo falcados y usualmente con algún tipo de indumento en la superficie externa.

Especímenes representativos examinados. HONDURAS. Atlántida: falda N de Pico Bonito, al SW de La Ceiba, 15.V.1993 (fl), Evans 1670 (EAP, MO, TEFH). Colón: río Guaimoreto, entre el 
puente Viejo y Laguna Guaimoreto, al NE de Trujillo, 27.IX.1981 (fl), Saunders \& al. 624 (BM, NY, TEX).

19. Pentalinon Voigt, Host. Suburb. Calcutt. 523. 1845

Lianas, tallos con secreción lechosa, glabros, glabrescentes o pubescentes, sin espinas o aguijones, coléteres intrapeciolares diminutos. Hojas opuestas, eglandulares, la lámina glabra, glabrescente a pubescente, pecioladas. Inflorescencias cimosas, axilares, subterminales o terminales, con pocas a muchas flores, brácteas escamiformes a foliáceas; cáliz con 5 sépalos, similares, diminutos, con varios coléteres en la base de la cara adaxial; corola infundibuliforme, sin corona anular o lóbulos coronales libres, amarilla o crema, limbo con 5 lóbulos, con estivación dextrorsa; estambres totalmente incluidos, anteras conniventes y aglutinadas a la cabeza estigmática, con conspicuos apéndices filiformes apicales, cabeza estigmática fusiforme, con un anillo en la base; gineceo bicarpelar, apocárpico, nectario anular, irregularmente lacerado en el ápice. Frutos en folículos apocárpicos, lisos y continuos, subleñosos; semillas desnudas y secas, rostradas y comosas en el ápice micropilar.

Género con 2 especies confinadas desde el S de Estados Unidos y las Antillas hasta Nicaragua, ambas presentes en Honduras (Hansen \& Wunderlin, 1986; Morales, 2005b; Woodson, 1936).

1. Brácteas florales ca. $1,5 \mathrm{~mm}$ de largo; parte inferior del tubo 9-16 mm de longitud; semillas (sin incluir la coma) 15-19 mm de largo 1. P. andrieuxii

1. Brácteas florales 7-12 mm de largo; parte inferior del tubo 6$8 \mathrm{~mm}$ de longitud; semilla (sin incluir la coma) 6-8 mm de largo

2. P. luteum

1. Pentalinon andrieuxii (Müll. Arg.) B.F. Hansen \& Wunderlin, Taxon 35(1): 168. 1986

Urechites andrieuxii Müll. Arg., Linnaea 30: 442.1860

Tipo: México. Oaxaca: cerca de Tehuantepec, VIII.1834 (fl, fr), Andrieux 247 (lectótipo, designado por Morales (2005b), G-DC [foto F neg. 26898]; isolectótipo, P). (Fig. 17 C).

Echites cupuliferus L.O. Williams, Fieldiana, Bot. 32(12): 179, f. 1.1970

Tipo: Guatemala. Petén: Tikal, Parque Nacional, 5.XI.1969 (fl), Ortíz 418 (holótipo, F [foto F neg. 56461]; isótipo, $\mathrm{MO}$ ).

Lianas, tallos glabros o puberulentos. Hojas con láminas 4,7-10,8 × 2,3-6,9 cm, elípticas, el ápice acuminado, la base obtusa, glabras o glabrescentes en el haz, glabras o esparcidamente puberulentas por el envés, pecíolo 0,9-2 cm de largo. Inflorescencia glabra o gla- brescente, pedicelos 1,8-3,9 cm de largo, brácteas ca. 1,5 mm de largo, diminutas; sépalos 4-6 mm de largo, ovados; corola verde-amarilla o amarilla, glabra, parte inferior del tubo 9-16 mm de largo, parte superior 2,24,4 cm de largo, tubular, 0,6-1,1 cm de diámetro en la fauce, lóbulos 1,3-2,3 × 0,9-1,1 cm, obovados; anteras 6-7 $\mathrm{mm}$ de largo, los apéndices apicales 7-10 $\mathrm{mm}$ de largo, ovario 1,5-2 mm de largo, glabro, nectario más largo que el ovario. Folículos $14-30 \mathrm{~cm} \times 5-8 \mathrm{~mm}$; semillas 1,5-1,9 cm de largo, coma 1,2-2,7 cm de largo.

Distribución. S de Estados Unidos (Florida) a Nicaragua. Bosques secos y bordes de manglares, en elevaciones de 0-500 m. Material con flores se ha recolectado entre agosto y noviembre.

Pentalinon andrieuxii se reconoce por brácteas florales diminutas, corolas con la parte inferior más larga (9-16 mm vs. 6-8 mm) y semillas más grandes. Adicionalmente esta especie sólo se encuentra en el territorio continental y no se conoce de las islas de la Bahía.

Especímenes representativos examinados. HONDURAS. Choluteca: cercanías de Cedeños, golfo de Fonseca, 11.X.1970 (fl), Molina E Molina 25882 (EAP, MO). Cortés: río Humuya, al N de Santa Cruz de Yojoa, 1-30.XI.1980 (fr), Nelson E al. 5801 (MO, TEFH). Santa Bárbara: río Ulúa entre Ilama y Gualala, 23.VIII.1968 (fl), Molina 22051 (EAP). Valle: Isla de Zacate Grande, La Guayaba, 1991 (fr), Andino 231 (TEFH); Amapala, 11.IX.1945 (fl, fr), Valerio 3343 (EAP), MO.

2. Pentalinon luteum (L.) B.F. Hansen \& Wunderlin, Taxon 35(1): 167. 1986

Vinca lutea L., Cent. Pl. 2: 12. 1756.

Urechites luteus (L.) Britton, Bull. New York Bot. Gard. 5:316. 1907

Tipo: "Habitat in Carolina", Catesby, Nat. Hist. Carolina, 2: 53, t. 53, 1736 (lectótipo, designado por Dandy, [1958]). (Fig. 17 D).

Liana, tallos hirsutos, glabros a glabrescentes con la edad. Hojas con láminas 1,7-5,8 × 1,1-3 cm, elípticas, ovadas, angostamente obovadas a lineares, el ápice obtuso a agudo, la base obtusa o aguda, glabras o variadamente pubescentes, sobretodo en la cara abaxial, pecíolo 0,4-1,4 cm de largo. Inflorescencia glabra, glabrescente o hirsuta, pedicelos 1,3-2,1 cm de largo, brácteas 7-12 mm de largo, foliáceas; sépalos 5-12 mm de largo, linear-ovados; corola amarilla, esparcidamente hirsuta a glabrescente, parte inferior del tubo 0,6-0,8 $\mathrm{cm}$ de largo, la parte superior de 1,4-2,3 cm de largo, tubular, con un diámetro $0,8-1,2 \mathrm{~cm}$ en la fauce, lóbulos 1,4-2,1 × 0,8-1,3 cm, obovados; anteras ca. $5 \mathrm{~mm}$ de largo, los apéndices apicales $9-11 \mathrm{~mm}$ de largo, ovario 1,2-1,5 mm de largo, glabro, nectario tan largo como el ovario. Folículos 13-20 cm $\times 1,5-3 \mathrm{~mm}$; semillas 0,6$0,8 \mathrm{~cm}$ de largo, coma 1,6-2,2 cm de largo, crema. 
Distribución. Principalmente las Antillas Mayores. En Honduras crece en ecosistemas de vegetación costeros, en elevaciones inferiores a los $100 \mathrm{~m}$. La floración se produce en mayo y junio. Especímenes con frutos fueron recolectados en septiembre.

Esta especie es un representante meramente caribeño que se conoce de Honduras y de Mesoamérica en general, sólo del departamento de las Islas de la Bahía. Se distingue con facilidad de la especie continental por sus flores y frutos más pequeños.

Especímenes representativos examinados. HONDURAS. Islas de la Bahía: Islas del Cisne, 17.V.1980 (fl), Cruz E Espinal 264 (TEFH); al E de la ciudad de Roatán, 9.IX.1982 (fr), Nelson 8312 (TEFH); Isla Santillana o de Swan, 10.VI.1986 (fl), Nelson E al. 9716 (TEFH)

\section{Plumeria L., Sp. Pl. 1: 209. 1753}

Árboles o arbustos, tallos con secreción lechosa, sin espinas o aguijones, coléteres intrapeciolares inconspicuos. Hojas alternas, eglandulares, láminas glabras o pubescentes, pecioladas. Inflorescencia en corimbos o cimas compuestas, terminales, con numerosas flores, brácteas escamiformes e inconspicuas; cáliz con 5 sépalos, similares, diminutos, sin coléteres en la base; corola hipocraterimorfa, sin corona anular o lóbulos coronales libres, blancas, crema, amarillas, rojizas a rosadas o fucsia o de colores variegados, limbo con 5 lóbulos, con estivación sinistrorsa; anteras no conniventes ni aglutinadas a la cabeza estigmática, cabeza estigmática levemente bicapitada; gineceo bicarpelar, apocárpico y semínfero, nectario ausente. Frutos folículos apocárpicos, lisos, continuos, algo leñosos al secar, semillas numerosas, aplanadas, desnudas y aladas en los márgenes, no comosas.

Género con 8-9 especies distribuidas desde México y las Antillas a las Guyanas, Venezuela, Perú y Bolivia, tres de ellas conocidas en Honduras (Woodson, 1938b). El ovario en Plumeria es semiínfero, algo bastante raro en las Apocynaceae s. str.

1. Hojas linear-elípticas ............................ 1. P. mariaelenae

1. Hojas angostamente elípticas, angostamente obovadas a obovadas .............................................................. 2

2. Flores densamente agrupadas, la inflorescencia aglomerada; folículos 8-18 cm de largo; semillas 2,6-3,2 cm de largo (Islas de la Bahía) ............................................. 2. P. obtusa

2. Flores laxamente dispuestas, la inflorescencia abierta; folículos 19-38 cm de largo; semillas 5,5-8 cm de largo (territorio continental)

3. P. rubra

1. Plumeria mariaelenae J. Gutiérrez \& J. Linares, Cactus Aventures 69: 4-7, pl. 1, 7, 8. 2006

Tipo: Honduras. Ocotepeque: Ocotepeque, quebrada El Salto de Cayaguanca (Ticacao o Tiana), 7,2 km S-SE de Nueva Ocotepeque, 20 mar 2005 (fl), Li- nares E Gutiérrez 8501 (holótipo, MEXU; isótipos, EAP, MEXU).

Árboles hasta $15 \mathrm{~m}$ de altura. Hojas con láminas 27$33 \times 3,5-5 \mathrm{~cm}$, linear-elípticas, el ápice acuminado, la base atenuada, glabras, pecíolo 5-7 cm de largo. Inflorescencia puberulenta, las flores densamente agrupadas, pedicelos 0,5-1,1 cm de largo, sépalos 1,4-2 mm de largo, ovados; corola blanco rosa, con tono rosados o rojizos en el tubo, tubo 1,7-2 cm de largo, lóbulos $5-5,8 \mathrm{~cm}$ de largo, obovados; anteras ca. $2 \mathrm{~mm}$ de largo, ovario 2$2,5 \mathrm{~mm}$ de largo. Folículos de 20-23,5 × 2,2-2,5 cm.

Distribución. Endémica a Honduras (pero de esperarse en el Salvador), donde se conoce del Departamento de Ocotepeque, en elevaciones de 1050 m. Flores se registran en marzo.

Plumeria mariaelenae fue descrita recientemente por Gutiérrez \& Linares (2006) y es incluida en este tratamiento de manera tentativa. No se pudo tener acceso al tipo o parátipos, por lo que la descripción es tomada directamente de esa referencia. Algunas de las diferencias entre $P$. rubra y este nuevo taxón citadas en el cuadro 1 de Gutiérrez \& Linares (2006) se traslapan al examinar el amplio rango de variación de P. rubra. La diferencia más notable es la forma de las hojas y el tamaño de la inflorescencia, aunque si bien, especímenes de P. rubra con inflorescencias muy reducidas han sido observados en Costa Rica, Colombia y Brasil. Es necesario un estudio detallado del material tipo para definir el estatus final de esta especie.

\section{Plumeria obtusa L., Sp. Pl. 1: 210. 1753}

Tipo: "Habitat in America calidiore", Catesby, Nat. Hist. Carolina, 2: t. 93. 1743. (lectótipo, designado por Dandy, [1958]). (Fig. 17 A).

Árboles o arbustos 2-7 m de altura, tallos glabros o puberulentos. Hojas con láminas 5,6-13,1 × 1,7-5 cm, angostamente obovadas, el ápice redondeado u obtuso, la base cuneada o atenuada, glabras en el haz, pubescentes o glabrescentes en el envés, pecíolo 1,2-2,1 cm de largo. Inflorescencia glabra o puberulenta, las flores densamente agrupadas, pedicelos 0,7-1,1 cm de largo, sépalos ca. $0,7 \mathrm{~mm}$ de largo, anchamente ovados; corola blanca, tubo 1-1,6 cm de largo, ca. 1,5 mm de diámetro en la fauce, lóbulos 1,8-4 × 1-1,3 cm, obovados; anteras ca. 1,5 mm de largo, ovario ca. $1 \mathrm{~mm}$. Folículos 8$18 \times 1,1-2,4 \mathrm{~cm}$; semillas 2,6-3,2 cm de largo.

Distribución. Península de Yucatán (México), Honduras y las Antillas. En Honduras sólo se conoce de las Islas de la Bahía, en elevaciones de 0-100 m. Especímenes con flores se han recolectado en junio.

Esta especie está restringida en Honduras a las Islas de la Bahía y hasta el momento no se conocen colec- 
ciones del territorio continental. En forma general Plumeria obtusa se diferencia de P. rubra por presentar inflorescencias aglomeradas, con las flores densamente agrupadas y por sus folículos y semillas más pequeños. Asimismo, sus hojas son consistentemente obovadas y usualmente de dimensiones más pequeñas. Sin embargo, estos últimos dos caracteres pueden traslaparse con el amplio rango de variación presente en P. rubra.

Espécimen representativo examinado. HONDURAS. Islas de la Bahía: Isla Santillana o de Swan, 10.VI.1986 (fl), Nelson E al. 9727 (MO, TEFH).

\section{Plumeria rubra L., Sp. Pl. 1: 209-210. 1753}

Tipo: Habitat in Jamaica, Surinamo, sin fecha (fl), Sloane, Voy. Jamaica, 2: 61, t. 185, f. 1, 1725 (lectótipo, designado por Wijnands (1983), BM-SL). (Fig. 2 D, 17 B).

Árboles o arbustos 2-8 $\mathrm{m}$ de altura, tallos glabros o puberulentos. Hojas con láminas 9,9-39,5 × 4-13,7 $\mathrm{cm}$, angostamente elípticas a obovadas, el ápice agudo o corto-acuminado, la base cuneada, glabras en el haz, pubescentes o glabrescentes en el envés, pecíolo 2-9 $\mathrm{cm}$ de largo. Inflorescencia glabrescente a puberulen$\mathrm{ta}$, las flores laxamente dispuestas, pedicelos 0,8-1,4 cm de largo, sépalos ca. $1 \mathrm{~mm}$ de largo, ovados; corola blanca, amarilla, roja o rosada, tubo 0,8-1,9 cm de largo, 3-4 mm de diámetro en la fauce, lóbulos 2,1-4 × 1,5-1,7 cm, obovados; anteras ca. $2 \mathrm{~mm}$ de largo, ovario ca. $1 \mathrm{~mm}$ de largo. Folículos $19-38 \times 2,5-3 \mathrm{~cm}$; semillas de 5,5-8 cm de largo.

Distribución. México y las Antillas a Venezuela y Perú, pero introducido en Brasil, Bolivia, Paraguay, Argentina y regiones tropicales de todo el mundo. Bosques secos, más rara en bosques húmedos, en elevaciones de 200-1400 m. Floración entre marzo y julio. Frutos entre enero y abril.

Nombres comunes. "Esquijoche", "Flor de Mayo" (Francisco Morazán); "Fragipani” (Intibucá); "Juche” (Francisco Morazán). Los siguientes nombres vernaculares fueron reportados por Nelson (2008): "Cacalichuche"; "Cacalochucho"; "Calachuche"; "Calichuche"; "Candelero"; "Flor de la cruz"; "Flor mestiza"; "Joche"; "Palo de la cruz"; "Sacalinchuche"; "Sacuanjoche".

Plumeria rubra es muy común en bosques secos, donde se reconoce al instante por sus hojas alternas, usualmente acróticas, inflorescencias terminales con numerosas flores blancas y el gran tamaño de sus folículos. Esta especie pierde sus hojas durante la época seca, durante la cual son producidos los frutos. Por otro lado, casi en forma invariable las poblaciones nativas tienen flores blancas, pero los numerosos culti-
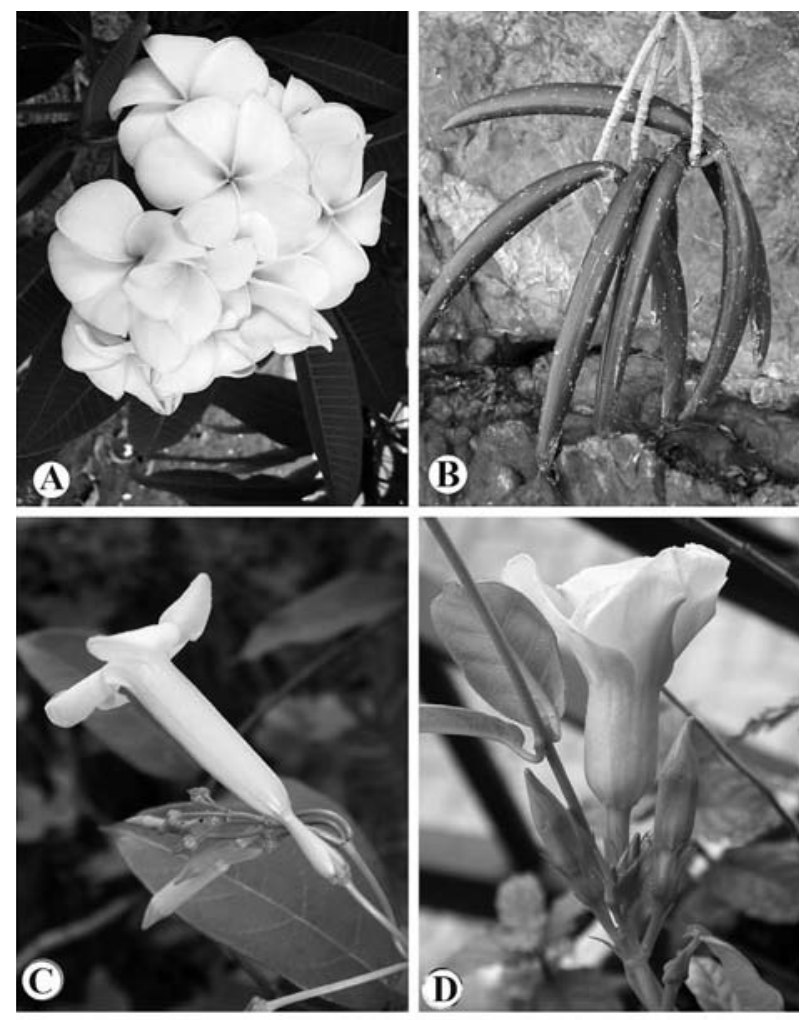

Fig. 17. Pentalinon y Plumeria. A, Plumeria obtusa; B, P. rubra; C, Pentalinon andrieuxii; C, P. luteum.

vares conocidos tienen un rango que varía del amarillo al rojo o rosado. Una mayor sinonimia puede ser consultada en Morales (2005a).

Especimenes representativos examinados. HONDURAS. Choluteca: San Juan de las Conchas, 1.IV.1998 (fl), Gordon 193 (EAP). Comayagua: quebrada El Destiladero, 4-25.IV.1992 (fr), Nelson E Andino 13712 (TEFH). Francisco Morazán: Nueva Tatumbla, al E de Tegucigalpa, 13.IV.1985 (fl, fr), Ferrera 166 (TEFH). Intibuca: río Otoro, 24.V.1970 (fl), Barkley E Hernández 40413 (TEFH). La Paz: río Chusmuya, III.cala, 3.V.1986 (fl), Keyser 1411 (TEFH). Lempira: cerca de Las Flores, entre Santa Rosa de Copán y Gracias, 13.V.1987 (fl), Blackmore E Chorley 3900 (MO, TEFH). Valle: Isla Zacate Grande, La Guayaba, 1991 (fl), Andino 245 (TEFH). Yoro: Coyoles, 25.VII.1938 (fl), Yuncker et al. 8613 (MO).

\section{Prestonia R. Br., Asclepiadaceae 58. 1810}

Lianas, tallos con secreción acuosa, lechoso-acuosa o acuosa, glabros a pubescentes, sin espinas o aguijones, coléteres intrapeciolares conspicuos o inconspicuos. Hojas opuestas, eglandulares, láminas glabras o pubescentes, pecioladas a subsésiles. Inflorescencias cimosas, umbeliformes a subumbeliformes, axilares o raramente terminales, con pocas o muchas flores, brácteas foliáceas a escariosas; cáliz con 5 sépalos, similares, inconspicuos a foliáceos, con 1 coléter solitario en la base; co- 
rola hipocraterimorfa o raramente infundibuliforme, crema, amarilla a verdosa y a veces variedaga con tonos rojizos o lilas, con una corona anular alrededor de la fauce, de manera usual con 5 lóbulos coronales libres en el interior y en forma opuesta a cada antera, o éstos ausentes y reducidos a callos o crestas callosas longitudinales, limbo con 5 lóbulos, con estivación dextrorsa; estambres totalmente incluidos o en el ápice exserto, anteras conniventes y aglutinadas a la cabeza estigmática, cabeza estigmática con forma de carrete de hilo, con un anillo membranoso basal; gineceo bicarpelar, apocárpico, nectario anular, lobulado o con cinco nectarios individuales. Frutos folículos apocárpicos, lisos o raramente alados, membranáceos o ligeramente leñosos al secar; semillas numerosas, secas, truncadas y comosas en el ápice micropilar.

Género con ca. 55 especies distribuidas desde el S de México y las Antillas hasta el N de Argentina; 4 son conocidas en Honduras (Morales, 1997d).

1. Hojas, tallos e inflorescencias conspicuamente pubescentes .

1. Hojas, tallos e inflorescencias glabros a glabrescentes ....... 3

2. Corola hipocraterimorfa; anteras 6-7 mm de largo ....

2. P. mexicana

2. Corola infundibuliforme; anteras $8-9 \mathrm{~mm}$ de largo

4. P. speciosa

3. Sépalos 3-6 mm de largo

1. P. longifolia

3. Sépalos 10-18 $\mathrm{mm}$ de largo

3. P. portobellensis

1. Prestonia longifolia (Sessé \& Moç.) J.F. Morales, Novon 6(3): 286. 1996

Echites longifolius Sessé \& Moç., Fl. Mexic. 45. 1893

Tipo: México. Veracruz: San Andrés Tuxtla, sin fecha (fl), Sessé E Moçiño 5007 (lectótipo, designado por Morales (1996a), MA; isolectótipo, F [foto, INB]). (Fig. $18 \mathrm{~A}$ ).

Belandra concolor S.F. Blake, Contr. Gray Herb. 52: 78-79. 1917

Prestonia concolor (S.F. Blake) Woodson, Field Mus.

Nat. Hist., Bot. Ser. 12: 327.1936

Tipo: Belice. Bancos del río Grande, 25.III.1907 (fl), Peck 953 (holótipo, GH [fotocopia, INB]).

Lianas, ramitas glabras a glabrescentes. Hojas con láminas de 8,5-22,5 × 2,9-9 cm, elípticas, el ápice cortamente acuminado, la base obtusa, glabras, pecíolo 6-18 m de largo. Inflorescencia glabra o inconspicuamente puberulenta, pedicelos $0,9-1,8 \mathrm{~cm}$ de largo, brácteas florales ca. $1 \mathrm{~mm}$ de largo, diminutas; sépalos 3-6 mm de largo, angostamente ovados; corola hipocraterimorfa, crema, glabra en la superficie externa, tubo 14-19 × 3,5-5 mm, lóbulos coronales 2-3 mm de largo, incluidos, lóbulos de la corola 7-11 mm de lar- go, obovados; anteras ca. $5 \mathrm{~mm}$ de largo, los ápices algo exertos, nectario $2-3 \mathrm{~mm}$ de largo, pentalobulado. Folículos 29-51 × 0,3-0,4 cm, continuos, glabros; semillas ca. $10 \mathrm{~mm}$ de largo, coma 1,5-3 cm de largo.

Distribución. México al $\mathrm{N}$ de Colombia. Bosques muy húmedos, en elevaciones de 100-900 m. Especímenes con flores se han recolectado en abril.

Prestonia longifolia pertenece a la sección Annulares (sensu Woodson, 1936), en donde la mayoría de las especies son virtualmente idénticas en estado vegetativo. De igual manera, esta especie es muy similar a $P$. portobellensis, pero se puede reconocer con facilidad por los caracteres dados en la clave. Sin embargo, especímenes con frutos pueden ser difíciles de separar.

Especimen representativo examinado. HONDURAS. Olancho: refugio de vida silvestre La Muralla, sendero El Pizote, 29.IV.1993 (fl), Nelson E Andino 15942 (TEFH).

2. Prestonia mexicana A. DC., Prodr. 8: 429. 1844 Mitozus mexicanus (A. DC.) Miers, Apocyn. S. Am. 225. 1878

Tipo: México. Oaxaca: San Bartolo, VIII.1834 (fl), Andrieux 251 (holótipo, G-DC; isótipos, FI-W, K [2 duplicados], P [foto F neg. 7542]). (Fig. 18 B).

Prestonia amanuensis Woodson, Ann. Missouri Bot. Gard. 23(2): 359. 1936

Tipo: Belice: 6 millas de línea Stan Creek, VIII. 1929 (fl), Schipp S-7 (lectótipo, designado por Morales (1997a), NY; isolectótipos F, GH, Z).

Lianas, ramitas pubescentes, algunas veces glabrescentes. Hojas con láminas 8,9-25 × 5,9-15,1 cm, elípticas, el ápice agudo, acuminado u obtuso, la base obtusa, puberulentas en el haz, tomentosas o tomentulosas en el envés, pecíolo $0,8-2 \mathrm{~cm}$ de largo. Inflorescencia tomentosa, pedicelos $0,7-3 \mathrm{~cm}$ de largo, brácteas florales 3-11 mm de largo, foliáceas; sépalos 14-30 mm de largo, ovados; corola hipocraterimorfa, crema, variadamente pubescente, tubo $24-35 \times 4-5$ $\mathrm{mm}$, lóbulos coronales ausentes, reducidos a crestas callosas, lóbulos de la corola 12-16 mm, obovados; anteras 6-7 mm de largo, incluidas o con los ápices exertos, nectario 1,5-3,5 mm de largo, entero o pentalobulado. Folículos 7,5-10 × 1-2 cm, divaricados, densamente pilosos o hirsutos; semillas 11-15 mm de largo, coma 2,5-4 cm de largo.

Distribución. México al NW de Colombia (Chocó). Bosques muy húmedos, bosques secos, en elevaciones de 0-1400 m. Floración se registró de junio a octubre.

Prestonia mexicana se puede confundir con $P$. speciosa, pero este último taxon tiene corolas infundibuliformes, en contraposición con P. mexicana, que tiene corolas hipocraterimorfas. 
Especímenes representativos examinados. HONDURAS. Cortés: Potrerillos, Aldea El Olivo, 13.IV.1975 (fr), Erazo 65 (MO). Francisco Morazán: quebrada Suyapa, NE de Tegucigalpa, 10.VIII.1949 (fl), Molina 2569 (BM, EAP, GH, US). Yoró: Cordillera Nombre de Dios, colinas al S de San José de Texiguat, 17.V.1991 (fl), Davidse E al. 34506 (INB, MO).

3. Prestonia portobellensis (Beurl.) Woodson, Ann. Missouri Bot. Gard. 18(4): 553. 1931

Echites portobellensis Beurl., Kongl. Vetensk. Acad. Handl. 1854: 137. 1856

Tipo: Panamá. Colón: Portobello, IV.1826, Billberg s.n. (holótipo, S [foto, MO]). (Figs. 4 C,D, 5, 7 B, 18 C).

Prestonia guatemalensis Woodson, Ann. Missouri Bot. Gard. 23(2): 339. 1936.

Tipo: Guatemala. Alta Verapaz: Sepacuitle, X.1901 (fl), Owen 1 (holótipo, US [foto, INB]).

Prestonia schippii Woodson, Ann. Missouri Bot. Gard. 23(2): 337-338. 1936

Tipo: Belice, El Dorado, IX.1922 (fl), Schipp S-388 (holótipo, F [foto F neg. 52873]).

Lianas, ramitas puberulentas o glabrescentes en la madurez. Hojas con láminas de 11,9-33,2 × 6,7-16,8 $\mathrm{cm}$, elípticas a obovadas, el ápice obtuso o cortamente acuminado, la base obtusa a redondeada, glabras a glabrescentes, pecíolo 0,9-2,8 cm de largo. Inflorescencia puberulenta, pedicelos 0,9-2,2 cm de largo, brácteas florales 1-3 mm de largo, diminutas; sépalos 10-18 mm de largo, angostamente elípticos; corola hipocraterimorfa, verde amarillenta, los lóbulos variada e irregularmente matizados con líneas y motas púrpura, glabra, tubo 13-18 × 6-7 mm, lóbulos coronales 4-5 mm de largo, los ápices exertos, lóbulos de la corola 9-16 mm de largo, obovados; anteras 5-6 mm de largo, los ápices levemente exertos, nectario entero a levemente pentalobulado. Folículos 33,5-62 × 0,6-0,8 cm, continuos y lisos, algunas veces unidos en el ápice, glabrescentes; semillas 10-20 mm de largo, coma 2,5-3 cm de largo.

Distribución. México a Colombia, el $\mathrm{N}$ de Venezuela y Ecuador. Bosques muy húmedos, entre 0-1100 m de elevación. Especímenes con flores se han recolectado en agosto y septiembre.

Nombres comunes. "Cacho de cabra", "Loroco" (Nelson, 2008).

Prestonia portobellensis se puede distinguir por sus tallos e inflorescencias aparentemente glabrescentes a simple vista, así como sépalos de 10-18 mm de largo. La coloración de los lóbulos de la corola de esta especie es una de las más llamativas de las Apocynaceae neotropicales, con una combinación de tonos lila, morados y amarillos.
Especímenes representativos examinados. HONDURAS. Atlántida: Tela, río Piedras Gordas, 15.VIII.1981 (fl), Nelson 7757 (US). Colón: Trujillo, río Negro, 7.IX.1980 (fl), Saunders 600 (MO, NY). Cortés: entre Agua Azul y Pito Solo, 26.VIII.1955 (fl), Molina 5565 (EAP, US).

4. Prestonia speciosa Donn. Sm., Bot. Gaz. 27(6): 435. 1899

Tipo: Guatemala. Santa Rosa: Buena Vista, IV.1893 (fl), Heyde E Lux 4497 (holótipo, US; isótipos, BM [foto INB], GH, K, US [3 pliegos]).

Prestonia grandiflora L.O. Williams, Fieldiana, Bot. 31(17): 402.1968

Tipo: México. Chiapas: La Grandeza, 19.V.1945 (fl), Matuda 15570 (holótipo, F; isótipos, EAP [2 pliegos], F [foto F neg. 56493 y 56494], MO [2 pliegos], $\mathrm{S}$, TEX-LL).

Lianas, ramitas pubescentes. Hojas con láminas 8,9-24,5 × 6,7-12,5 cm, obovadas a orbiculares, el ápice acuminado, la base cuneada a obtusa, puberulentas a glabrescentes en el haz, tomentosas por el envés, pecíolo de 4-10 mm de largo. Inflorescencia tomentulosa, pedicelos 0,9-1,5 cm de largo, brácteas florales 3$12 \mathrm{~mm}$ de largo, foliáceas; sépalos 9-18 mm de largo, ovados a elípticos; corola infundibuliforme, amarilla, tomentulosa, parte inferior del tubo de 12-19 × 3-4 $\mathrm{mm}$, la parte superior de $10-20 \times 10-20 \mathrm{~mm}$ en diam. en la fauce, cónica, lóbulos coronales ausentes, lóbulos de la corola 20-25 mm, obovados; anteras 8-9 mm de largo, incluidas, nectario 3-3,5 mm de largo, pentalobulado a lacerado. Folículos 7-9 × 1,8-2,7 cm, divaricados, densamente seríceos o tomentulosos; semillas 12-14 mm de largo, coma 2-3 cm de largo.

Distribución. México a Nicaragua (excepto Belice). Bosques muy húmedos, en elevaciones de 1000-1600 $\mathrm{m}$. Especímenes con flores se han recolectado en enero y mayo.

Los miembros de la sección Tomentosae (sensu Woodson, 1936) son morfológicamente similares y en algunos casos, ante la ausencia de material fértil, la separación a nivel de especie puede ser compleja o, a veces, imposible. De esta manera, aunque las flores de Prestonia speciosa son notablemente diferentes a las de P. mexicana, las colecciones con frutos son virtualmente idénticas y en estado vegetativo ambas son imposibles de separar. En todo su rango de distribución, casi no se conocen especímenes con frutos de P. speciosa.

Especimenes representativos examinados. HONDURAS. Comayagua: Comayagua, 1980 (fl), Nelson \& al. 6616 (EAP, MO). Copán: W de Copán, 1.VIII.1977 (st), Croat 45520 (MO). Yoró: Yoró, I.1981 (fl), Nelson \& al. 7292 (EAP, MO). 


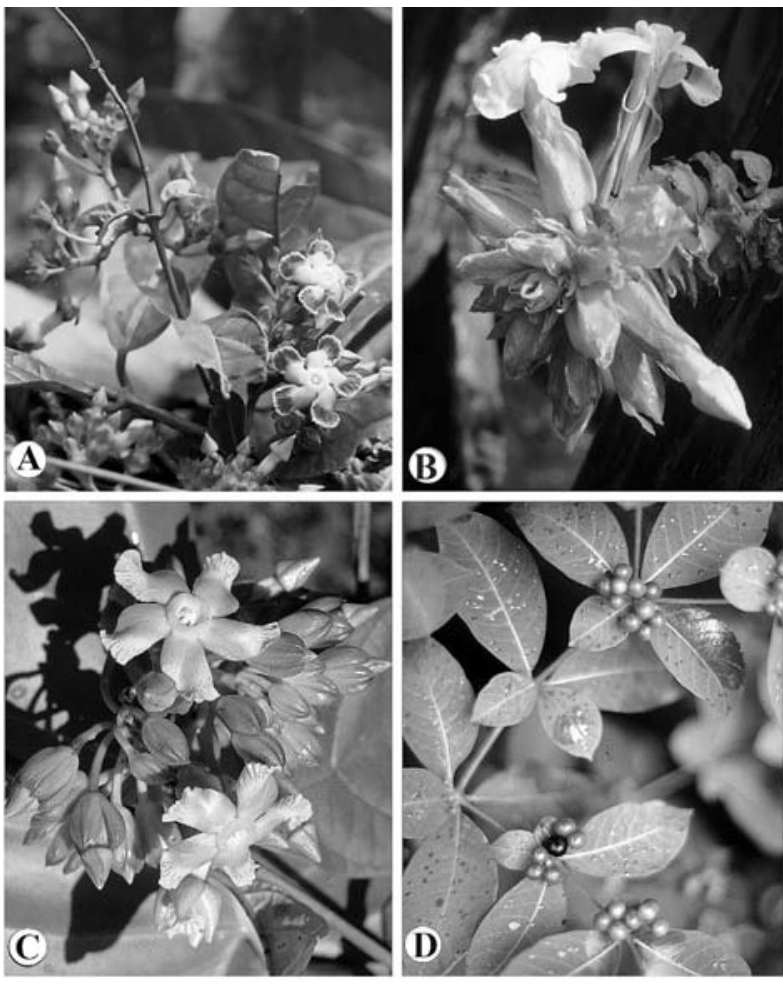

Fig. 18. Prestonia y Rauvolfia. A, Prestonia longifolia; B, P. mexicana; C, P. portobellensis; D, Rauvolfia tetraphylla.

\section{Rauvolfia L., Sp. Pl. 1: 208. 1753}

Arbustos, árboles o hierbas arbustivas, tallos con secreción lechosa, glabros a pubescentes, sin espinas o aguijones, coléteres intrapeciolares inconspicuos. Hojas verticiladas, algunas veces con coléteres en los pecíolos, láminas glabras a pubescentes, pecioladas o sésiles. Inflorescencias cimosas, terminales o axilares, algunas veces interpeciolares, con pocas o muchas flores, brácteas escamiformes; cáliz con 5 sépalos, similares, diminutos, sin coléteres; corola hipocraterimorfa, infundibuliforme, urceolada o campanulada, sin corona anular o lóbulos coronales libres, blancas, cremas, verdosas o rosadas, limbo con cinco lóbulos, con estivación sinistrorsa; estambres incluidos, anteras no conniventes ni aglutinadas a la cabeza estigmática, cabeza estigmática más o menos cilíndrica; gineceo bicarpelar, apocárpico o sincárpico, nectario anular, entero o lobulado. Frutos drupas apocárpicas o sincárpicas (algunas veces sólo un carpelo desarrollado), carnosas, con 1 a 2 semillas, desnudas.

Género pantropical con ca. de 100 especies (35 en el neotrópico y 65 en el paleotrópico); 1 sola presente en Honduras (Rao, 1956).

1. Rauvolfia tetraphylla L., Sp. Pl. 1: 208. 1753. (Fig. $3 \mathrm{D}, 18 \mathrm{D})$.
Tipo: Habitat in America calidiore, sin fecha (fl), Herb. Clifford 75, Rauvolfia No. 1, (lectótipo, designado por Stearn, (1957), BM).

Arbustos 0,5-1,5 m, tallos glabros o pubescentes. Hojas en verticilos de 4 , fuertemente anisofilas, la lámina en las hojas más largas 5,4-12,7 × 2,8-5,8 cm, las más cortas 1,1-4 ×0,8-3 cm, elípticas a ovadas, el ápice agudo, corto-acuminado u obtuso, la base cuneada, glabras o pubescentes, pecíolo 1-8 mm de largo, con varios coléteres en la superficie adaxial. Inflorescencias glabras a puberulentas, pedicelos 1-4 mm de largo; sépalos ca. $1 \mathrm{~mm}$ de largo, ovados; corola urceolada, blanca o crema, tubo 2-3 mm de largo, lóbulos ca. $1 \mathrm{~mm}$ de largo, obovados; anteras ca. $1 \mathrm{~mm}$ de largo. Frutos 5-7 mm de largo, esféricos, rojos, anaranjados o morados al madurar.

Distribución. México y las Antillas a Venezuela, y Perú; introducida en Estados Unidos y África. Bosques de pinos y bosques secos, en elevaciones de 0 $1200 \mathrm{~m}$. Flores y frutos son producidos de manera irregular durante todo el año.

Nombres comunes. "Alcotán" (Francisco Morazán); "Amatillo" (El Paraíso); "Comida de culebra" (Choluteca); "Fruta de culebra" (Olancho); "Hombre grande" (Yoro); "Leche de Burro" (Olancho); "Matiar" (Copán); "Tomatillo", "Tomatillo de árbol" (Olancho). Nelson (2008) reporta los siguientes nombres: "Amor de hombre"; "Chalchuapa"; "Matacoyote"; "Señorita"; "Viborilla". Usos: "Sirve para curar hinchazones" (Nelson 7048, TEFH).

Rauvolfia tetraphylla es una de las Apocynaceae más comunes en Honduras, donde puede ser encontrada en áreas abiertas o de regeneración secundaria. Se puede distinguir por sus hojas dispuestas en verticilos, anisofilas, con dos de ellas más pequeñas que las otras dos, así como por sus flores diminutas y frutos drupáceos de color morado, rojo, o anaranjado al madurar.

Especímenes representativos examinados. HONDURAS. Atlántida: entre Tocoa y La Ceiba, río Sambo, 9.II.1987 (fl, fr), Croat E Hannon 64556 (EAP, MO). Choluteca: cercanías de Pespire, 1827.X.1950 (fr), Standley 27159 (EAP). Colón: Cerro Capiro, 30.XII.1979 (fl, fr), Villela 143 (MO). Comayagua: Chichipates, río Yure, 22 Nov-31.XII.1980 (fr), Nelson \& al. 6595 (MO, TEFH). Copán: ruinas de Copán, 7.V.1970 (fl, fr), Barkley E Hernández 40274 (TEFH). Cortés: entre San Pedro Sula y Cortés, cerca de Choloma, 19.IV.1956 (fr), Molina 6664 (EAP). El Paraíso: valle Jamastrán, 15.VII.1956 (fl), Molina 7502 (EAP). Francisco Morazán: carretera Pedregal, cerca de Cuesta Grande, drenaje del río Yeguare, 12.VIII.1947 (fl, fr), Williams E Molina 13266 (EAP, MO). Islas de la Bahía: Isla de Roatán, 13.VIII.1997 (fl), Nelson E Calera 19551 (TEFH). La Paz: La Paz, 2.IX.1979 (fl), Soto 78 (MO). Ocotepeque: aldea de Pimienta, río Ulúa, 810.III.1974 (fr), Nelson E al. 1693 (TEFH). Olancho: río Olancho, entre Tegucigalpa y Catacamas, 4.II.1987 (fr), Croat \& Hannon 64080 (EAP, MO). Santa Bárbara: Ocotal Tupido, carretera a San Pedro Sula a Ocotepeque, 14.IX.2001 (fr), Nelson E al. 21095 
(TEFH). Valle: Amapala, 11.IX.1945 (fl, fr), Valerio 3353 (EAP, MO). Yoro: Olanchito, San José, río Agalteca, 2.VII.1994 (fl, fr), Davidse E al. 35505 (EAP, MO).

23. Rhabdadenia Müll. Arg., Fl. Bras. 6(1): 173. 1860

Lianas o hierbas suberectas, tallos con secreción lechosa, glabros a puberulentos, sin espinas o aguijones, coléteres intrapeciolares inconspicuos. Hojas opuestas, eglandulares, láminas usualmente glabras, raramente puberulentas, pecioladas a subsésiles. Inflorescencias cimosas, reducidas, axilares o subterminales, con menos de 4 flores, brácteas escamiformes; cáliz con 5 sépalos, similares, diminutos a subfoliáceos, sin coléteres en la base; corola infundibuliforme, sin corona anular o lóbulos coronales, rosada, blanco-rosada a casi blanca, limbo con 5 lóbulos, con estivación dextrorsa; estambres incluidos, anteras conniventes y aglutinados a la cabeza estigmática, ésta con forma de carrete de hilo; gineceo bicarpelar, apocárpico, nectarios 5, separados o en la base connados y formando un nectario pentalobulado. Frutos folículos apocárpicos, continuos, membranáceos; semillas numerosas, secas, rostradas y comosas en el ápice micropilar.

Género con 3 especies distribuidas desde México y las Antillas hasta Argentina, una registrada en Honduras (Woodson, 1936).

1. Rhabdadenia biflora (Jacq.) Müll. Arg., Fl. Bras. 6(1): 175.1860

Echites biflorus Jacq., Enum. Syst. Pl. 13. 1760

Tipo: Antillas, Plumier, Bot. Amer. 1, t. 96. 16891697. (Fig. 19 A).

Rhabdadenia macrantha Donn. Sm., Bot. Gaz. 40(1): 7. 1905

Tipo: Honduras. Cortez: Puerto Sierra, I.1903 (fl), Wilson 244 (holótipo, US; isótipo, NY).

Lianas, tallos glabros. Hojas 3,3-10,8 × 0,7-3,8 cm, elípticas, el ápice obtuso y mucronado, la base obtusa, glabras, pecíolo $0,8-1,7 \mathrm{~cm}$ de largo. Inflorescencia muy reducida, con 1 a 3(4) flores, pedicelos 1,3-2,1 cm de largo, brácteas ca. 1,5 mm de largo; sépalos 3$11 \mathrm{~mm}$ de largo, angostamente ovados; corola blanca o rosada, parte inferior del tubo 1,2-1,9 cm de largo, la parte superior 1,9-2,6 cm de largo, cónica, 1,3-1,5 cm de diámetro en la fauce, lóbulos de 1,9-2,4 cm de largo, obovados; anteras ca. $4 \mathrm{~mm}$ de largo, nectarios tan largos como el ovario, separados. Folículos 9-18 cm, glabros, rectos; semillas de 2,8-3,8 cm de largo.

Distribución. S de Estados Unidos (Florida) y las Antillas a Ecuador y Brasil, en manglares y áreas asociadas en elevaciones bajo los $50 \mathrm{~m}$. La floración ocurre durante todo el año.
Rhabdadenia biflora se puede reconocer con facilidad por su hábitat restringido a manglares y zonas aledañas, hojas sin coléteres en el nervio central e inflorescencias cimosas reducidas normalmente a 2 flores (con un rango de 1 a 4), con corolas blancas a blancorosadas.

Especimenes representativos examinados. HONDURAS. Atlántida: Laguna Los Micos, NW de Tela, 10.XI.1988 (fl), MacDougal E al. 3435 (MO, WAG). Colón: Puerto Castilla, 17-20.VII.1973 (fl), Nelson \& Martínez 1154 (EAP). Cortes: playas de Tulián, 16.VI.1952 (fl), Molina 5208 (EAP, US). Gracias a Dios: Tuas, W de Brus, IV.1971 (fl), Nelson E Hernández 968 (EAP, MO). Islas de la Bahía: Isla de Roatán, 19.IV.1967 (fl), Molina 20648 (EAP, US).

24. Stemmadenia Benth., Bot. Voy. Sulphur 124. 1844 [1845]

Arbustos o árboles, tallos con secreción lechosa, glabros o pubescentes, coléteres intrapeciolares inconspicuos. Hojas opuestas, eglandulares, láminas glabras o pubescentes, pecioladas. Inflorescencias cimosas, axilares o subterminales, con pocas flores, a veces reducidas a flores solitarias, glabras a pubescentes, brácteas escamiformes a foliáceas; cáliz con 5 sépalos, similares o conspicuamente desiguales, diminutos a foliáceos, con numerosos coléteres en la base; corola hipocraterimorfa o infundibuliforme, blanca o amarilla, sin corona anular o lóbulos coronales, tubo con 5 crestas supra e infraestaminales, a veces con una fuerte torción en la posición de los estambres, limbo con 5 lóbulos, con estivación sinistrorsa; estambres incluidos, anteras no conniventes ni aglutinadas a la cabeza estigmática, cabeza estigmática subglobosa, con un collar basal; gineceo bicarpelar, apocárpico, nectario anular. Frutos folículos apocárpicos, carnosos, de formas variadas; semillas numerosas, desnudas, rodeadas por un arilo carnoso, anaranjado o amarillento

Género con 16 especies distribuidas desde México al $\mathrm{N}$ de Brasil, Ecuador, Perú y Bolivia, 3 de ellas conocidas en Honduras (Alvarado-Cárdenas, 2007; Leeuwenberg, 1994; Morales \& Méndez, 2005).

1. Corola infundibuliforme, $14-16 \mathrm{~mm}$ de diámetro en la fauce 3. S. pubescens

1. Corola hipocraterimorfa, 4,5-6 mm de diámetro en la fauce

2. Sépalos marcadamente desiguales en longitud, con series externas mucho más pequeñas que las internas, las diferencias en longitud más de 1/3 de largo total del sépalo; tubo 20-28 $\mathrm{mm}$ de largo .................................. 1. S. donnell-smithii

2. Sépalos relativamente similares en longitud, a veces algunos levemente más pequeños, pero la diferencia menos de 1/5 de la longitud total del sépalo; tubo 14-21 mm de largo

2. S. eubracteata

1. Stemmadenia donnell-smithii (Rose) Woodson, Ann. Missouri Bot. Gard. 15(4): 369. 1928 
Tabernaemontana donnell-smithii Rose, Bot. Gaz. 18(6): 206. 1893

Tipo: Guatemala. etalhuleu, San Felipe, IV.1896 (fl), Donnell-Smith 2763 (lectótipo, designado por Woodson (1928), US; isolectótipos, A, F [2 pliegos, foto F neg. 56565 y 56566], G, GH, K, M, MO, NY, US [2 pliegos]). (Fig. 4 B, 6 C, 19 B,C).

Árboles o arbustos 3-9 $\mathrm{m}$ de largo, tallos glabros a puberulentos. Hojas 4,5-17,2 × 2,2-5,1 cm, elípticas a obovadas, el ápice acuminado, la base obtusa, glabras en el haz, pubescentes en el envés, sobretodo a lo largo de las axilas del nervio central, pecíolo $0,3-1,1 \mathrm{~cm}$ de largo. Inflorescencia con 1-4 flores, pedicelos 0,51,1 cm de largo, brácteas 2-3 mm de largo; sépalos desiguales, en dos series, los exteriores 4-9 mm de largo, los internos 14-17 mm de largo, angostamente ovados; corola hipocraterimorfa, amarilla, tubo $2-2,8 \mathrm{~cm}$ de largo, 5-6 mm de diámetro en la fauce, lóbulos 13 $18 \mathrm{~cm}$ de largo, obovados; anteras 4-5 mm de largo, ovario 2-3 mm de largo, nectario ca. la mitad de la longitud del ovario. Frutos 5-8,5 × 4-7 cm, grisáceos o verde-grisáceos al madurar; semillas $0,9-1,1 \mathrm{~cm}$ de largo.

Distribución. México a Panamá. Bosques muy húmedos a bosques secos, entre 0-100 m. Floración y fructificación se producen de manera continua durante todo el año.

Nombres comunes. "Cojón de Mico" (Atlántida); "Cojón de Burro" (Copán, Cortés); "Cojón de Potro" (Olancho); "Huevos de burro" (Santa Bárbara, Olancho). Los siguientes nombres fueron reportados por Nelson (2008): "Buksa mahbra" (mískito); "Huevo de caballo"; "Huevo de toro"; "Huevos de chancho"; "Quiebramuela".

Stemmadenia donnell-smithii se distingue con facilidad por sus sépalos marcadamente desiguales, con una serie externa mucho más pequeña en longitud que la interna. Otros caracteres útiles se refieren a la presencia de mechones de pelos a lo largo del nervio central abaxialmente (aunque a veces pueden estar ausentes), así como la usual coloración grisácea de los folículos al madurar.

Especimenes representativos examinados. HONDURAS. Atlántida: jardín botánico de Lancetilla, 21.XII.1993 (fr), Nelson E Andino 16794 (TEFH). Choluteca: al N de Jícaro Galán, 23.XII.1975 (fr), Nelson E al. 3203 (MO, TEFH). Comayagua: entre La Misión y Taulabé, 27.IX.1963 (fl), Molina 13013 (EAP). Colón: Trujillo, río Negro, 11-12.VIII.1973 (fl), Clewell E al. 4329 (MO, EAP). Copán: montaña el Nace, al NE de las ruinas de Copán, 14.II.2001 (fl), Dirección General de Biodiversidad SERNA 21 (EAP). Cortés: entre Tapiquilar y Las Crucitas, al S de San Antonio de Cortés, 23.II.1982 (fr), Nelson E al. 8113 (MO, TEFH). Olancho: río Talgua, al NE de Catacamas, 5.IV.1987 (fr), Ortega 261 (MO, TEFH). Santa Bárbara: lago Yojoa, 24.V.1972 (fl), Clewell 3113 (EAP, MO, TEFH). Yoró: vaguada del río Jalegua, al N de Yoró, 28.III-4.IV.1974 (fr), Nelson E Martínez 1963 (TEFH).

2. Stemmadenia eubracteata Woodson, Ann. Missouri Bot. Gard. 15(4): 368, t. 49, f. 2. 1928

Tipo: Guatemala. Santa Rosa: Volcán de Tecuamburro, II.1893 (fl), Heyde E Lux 4538 (holótipo, GH; isótipos, BM, F, K, M, US). (Fig. 19 D).

Arbustos o árboles 1,5-3 m de altura, tallos glabros. Hojas: lámina 3,5-12,4 × 2,1-4,2 cm, elípticas, el ápice acuminado, la base obtusa, glabras o glabrescentes, pecíolo 2-8 mm de largo. Inflorescencia con 1-4 flores, pedicelos 4-7 $\mathrm{mm}$ de largo, brácteas $0,5-3,5 \mathrm{~mm}$ de largo; sépalos iguales a subiguales, $5-11 \mathrm{~mm}$ de largo, angostamente elípticos; corola angostamente infundibuliforme, el tubo expandido en el tercio distal, amarilla, tubo 1,4-2,1 cm de largo, con un diámetro de 4,5-6 mm en la fauce, torcido en espiral sobre la posición de los estambres, lóbulos 1,3-1,7 cm de largo, obovados; anteras ca. 3,5 mm de largo, ovario 1,5-2 $\mathrm{mm}$ de largo, disco ca. la mitad de la longitud del ovario. Frutos 2-2,5 × 1,2-1,4 cm, verdes o verde-amarillentos al madurar.

Distribución. S de México, Guatemala y El Salvador, en bosques húmedos y vegetación secundaria relacionada, entre 650-1150 m de elevación. Especímenes con frutos se han recolectado en enero, septiembre y octubre.

Nombres comunes. "Huevos de chancho" (Copán); "Chilca" (Nelson, 2008).

En Honduras esta especie se registra por primera vez, donde se distingue por sus hojas glabras o glabrescentes, sépalos de longitudes similares, persistentes en fructificación y por el tamano del tubo de la corola y frutos. Stemmadenia eubracteata fue incluida en la sinonimia de S. macropbylla Greenm. por Leeuwenberg (1994). Sin embargo, recientemente Morales \& Méndez (2005) demostraron que la primera especie debía excluirse de la sinonimia y tratarse como un taxón válido. La historia taxonómica relacionada con esta especie es compleja y se sugiere el estudio del trabajo de Morales \& Méndez (2005).

Espécimen representativo examinado. HONDURAS. Comayagua: río Avilla, Lejamaní, 5.X.1983 (fr), Holst 1363 (EAP). Copán: ruinas de Copán, 2.I.1983 (fr), Molina E al. 32099 (EAP).

3. Stemmadenia pubescens Benth., Bot. Voy. Sulphur. 125. 1845

Bignonia (?) obovata Hook. \& Arn., Bot. Beechey Voy. 439. 1841, nom. illeg., no Spreng. (1825)

Stemmadenia obovata K. Schum., Nat. Pflanzenfam. 4(2): 149. 1895, nom. illeg 

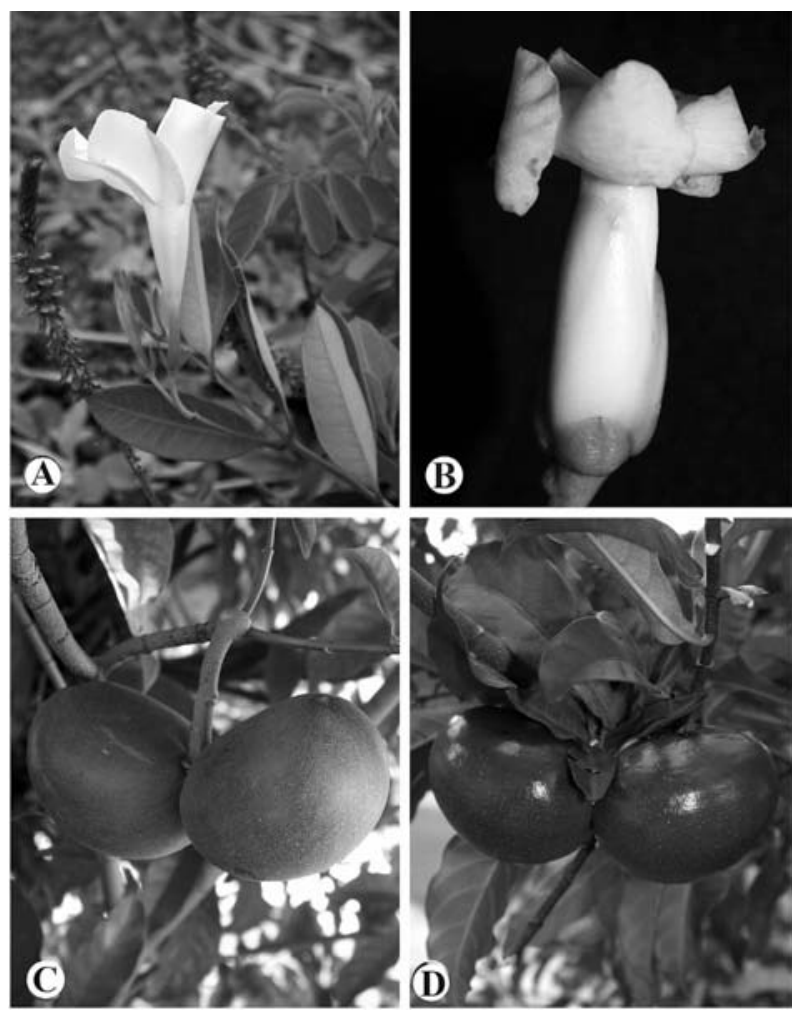

Fig. 19. Rhabdadenia y Stemmadenia. A, Rhabdadenia biflora; B,C, Stemmadenia donnell-smithii; D, S. eubracteata.

Tipo: México. San Luis Potosí: Realejo, sin fecha (fl), Sinclair s.n. (holótipo, K; isótipo, K [fotos, INB]). (Fig. 20 A,B).

Stemmadenia glabra Benth., Bot. Voy. Sulphur 124, t. 44. 1845

Tipo: Honduras. Valle: Golfo de Fonseca, Choluteca, sin fecha (fl), Sinclair s.n. (lectótipo, designado por Nelson (1996), K [2 pliegos, fotos, INB]).

Stemmadenia mollis Benth., Bot. Voy. Sulphur 125. 1845 Stemmadenia obovata Benth. var. mollis (Benth.) Woodson, Ann. Missouri Bot. Gard. 15(4): 358. 1928

Tipo: Ecuador. Guayaquil: Guayas, sin fecha (fl), Sinclair s.n. (holótipo, K [fotos, INB]).

Arbustos de 1-6 m de altura, ramitas pubescentes, raramente glabrescentes. Hojas 3,9-23,2 × 2-10,8 cm, elípticas a obovadas, el ápice corto-acuminado, la base aguda a obtusa, pubescentes, sobre todo en el envés, algunas veces glabrescentes, pecíolo $0,5-1,2 \mathrm{~cm}$ de largo. Inflorescencia con 1-6 flores, pedicelos 0,9$2,3 \mathrm{~cm}$ de largo, brácteas de 2-6 mm; sépalos desiguales, en 2 series, 0,8-2,8 × 0,5-0,8 cm, anchamente ovados a angostamente obovados; corola infundibuliforme, amarilla, parte inferior del tubo 2-2,5 cm de largo, la parte superior 2-2,5 cm de largo, cónica, 1,4-1,6 cm de diámetro en la fauce, lóbulos 2-3,4 × 1,7-2,5 cm, obovados; anteras 4-5 mm de largo, ovario ca. $2 \mathrm{~mm}$ de largo, nectario pentalobulado, más pequeño que el ovario. Frutos 3,5-5,3 × 2-4,1 cm, verde-amarillentos al madurar; semillas 0,7-0,9 cm de largo.

Distribución. México a Colombia, Ecuador, Perú y Bolivia. Bosques secos, en elevaciones de 0-900 m. La floración ocurre durante todo el año, pero con mayor intensidad de enero a octubre.

Nombres comunes. "Cojón" (Valle); "Cojón de burro" (Comayagua, Francisco Morazán); "Quiebramuelas" (Comayagua); "Cojón de puerco" (Choluteca); "Huevos de chancho" (Valle). Nelson (2008) reporta "Barquillo"; "Chivo".

En Honduras, Stemmadenia pubescens, es la especie más fácil de reconocer por el tamaño de su corola. En general, en Centroamérica es relativamente común en bosques secos y puede llegar a ser un arbusto dominante en áreas en regeneración temprana; sin embargo, las colecciones de Sudamérica son muy escasas. Para una explicación más detallada sobre la historia taxonómica de este taxón, véase el trabajo de Morales \& Méndez (2005).

Especimenes representativos examinados. HONDURAS. Choluteca: cercanías de Pespire, 18-25.X.1950 (fl), Standley 27012 (EAP). Comayagua: Comayagua, 22.V.1972 (fl), Clewell 3079 (EAP, MO, TEFH). Cortés: Cofradía, entrte Chamelecon y Santa Rosa, 30.X.1965 (fl), Dickson 1636 (EAP). El Paraíso: entre Yuscarán y Oropoli, 11.VII.1961 (fr), Eilers 910 (EAP). Francisco Morazán: drenaje del río Yeguare, 25.IV.1948 (fl), Williams E Molina 14081 (EAP). La Paz: al N de La Paz, 28.IV.1983 (fl), Holst 1060 (EAP, TEFH). Santa Bárbara: río Ulúa, entre Ilama y Gualala, 23.VIII.1968 (fl), Molina 22029 (EAP). Valle: Amapala, Isla del Tigre, 4.IV.1981 (fl), Nelson E Martínez 7749 (MO, TEFH).

\section{Tabernaemontana L., Sp. Pl. 1: 210. 1753}

Arbustos o árboles, tallos con secreción lechosa, coléteres interpeciolares inconspicuos. Hojas opuestas, eglandulares, láminas glabras a puberulentas, pecioladas a subsésiles. Inflorescencias cimosas o panículas, axilares o subterminales, con pocas a muchas flores, brácteas escamiformes; cáliz con 5 sépalos,similares, diminutos a foliáceos, con numerosos coléteres en la base; corola hipocraterimorfa, sin corona anular o lóbulos coronales libres, de colores variados, limbo con 5 lóbulos, con estivación sinistrorsa; estambres incluidos o con los ápices exertos, anteras no conniventes ni aglutinadas a la cabeza estigmática, cabeza estigmática con un anillo basal y más o menos fusiforme o pentagonal arriba; gineceo bicarpelar, apocárpico, nectario ausente o presente. Frutos folículos apocárpicos, de formas variadas, lisos o murica- 
dos, carnosos; semillas numerosas, rodeadas por un arilo carnoso, anaranjado o amarillento al madurar.

Género pantropical con ca. de 100 especies, 45 de ellas en el neotrópico; 4 de ellas registradas en Honduras (Leeuwenberg, 1994).

1. Anteras insertas en la base del tubo de la corola 3. T. arborea

1. Anteras insertas en la mitad distal del tubo, justo bajo la fau-

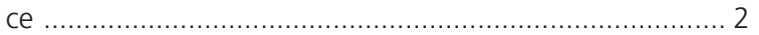

2. Corola generalmente con doble serie de lóbulos; anteras 4-6 $\mathrm{mm}$ de largo (cultivadas)

4. T. divaricata

2. Corola con una sola serie de lóbulos; anteras 2,5-4 mm de largo

3. Corola verde-crema, el tubo 4-8 mm de largo; semillas 9-11 $\mathrm{mm}$ de largo

1. T. alba

3. Corola blanca, el tubo 12-15 mm de largo; semillas 6-7 mm de largo

2. T. amygdalifolia

1. Tabernaemontana alba Mill., Gard. Dict. (ed. 8). 2. 1768

Tipo: México. Veracruz: Veracruz, 1730, Houston s.n. (holótipo, BM [fotos, BM, NY, US]; isótipo, CGE). (Fig. 20 C).

Árboles o arbustos 1-5 m de altura, tallos glabros. Hojas 6,5-18,3 × 3,1-6,5 cm, elípticas a angostamente obovadas, el ápice obtuso-acuminado, la base cuneada, glabra, pecíolo 0,5-2,2 cm de largo. Inflorescencia erecta o péndula, con muchas flores, pedicelos 5-15 $\mathrm{mm}$ de largo, brácteas ca. $2 \mathrm{~mm}$ de largo; sépalos 1,5$2 \mathrm{~mm}$ de largo, ovados; corola verde-crema, tubo 4-8 $\mathrm{mm}$ de largo, ca. 1,5 mm de diámetro en la fauce, lóbulos de 8-13 mm, angostamente obovados; estambres insertos en la parte superior del tubo, anteras 2,5$3 \mathrm{~mm}$ de largo, incluidas o en el ápice exertas, nectario casi inconspicuo, subentero. Frutos 2-3,3 × 1,5-2,3 $\mathrm{cm}$, verde-amarillento al madurar, lisos; semillas 0,9 $1,1 \mathrm{~cm}$ de largo.

Distribución. México y las Antillas Mayores al NW de Colombia. Bosques secos y bosques muy húmedos, en elevaciones de 0-850 m. Especímenes con flores y frutos se han recolectado entre marzo y diciembre.

Nombres comunes. "Chanchito" (Colón); "Cojón" (Olancho); "Cojón de burro" (Comayagua, Olancho); "Cojón de Mico" (Atlántida); "Huevo de Mono" (Atlántida). Nelson (2008) reporta los siguientes nombres: "Buksa mahbra" (mískito, cojón de danto); "Chapupo"; "Cojón de gato"; "Cojón de mono"; "Huevo de chancho"; "Waku" (tawahka).

Tabernaemontana alba se puede distinguir por la siguiente combinación de caracteres: corola amarilla o verde-crema, el tubo de 4-8 $\mathrm{mm}$ de largo, anteras insertas en la mitad distal del tubo, incluidas o con solo en ápice levemente exerto y semillas de $9-12 \mathrm{~mm}$ de largo. Esta especie es la más común del género en Honduras, llegando a ser un arbusto dominante en algunas zonas.

Especimenes representativos examinados. HONDURAS. Atlántida: Puerto Escondido, 13-16.VIII.1982 (fl), Soto EEspinal 283 (MO, TEFH). Choluteca: Isla Zacate Grande, La Guayaba, 9.V.1991 (fr), Colindres 201 (TEFH). Colón: al E de Trujillo, río Selen, 7.VI.1980 (fl), Saunders 303 (MO, TEFH). Comayagua: lago Yojoa, 29.V.1972 (fl), Clewell 3194 (EAP, MO, TEFH). Copán: río Tepemechin, 12.IX.1973 (fl), Hazlett 753 (MO). Cortes: Corinto, 9-11.VIII.1975 (fl), Nelson et al.2868 (MO, TEFH). El Paraíso: río Guayambre, Valle Jamastrán, $13 . I I I .1956$ (fl), Molina 7360 (EAP); montaña Cifuentes, entre El Urraco y Cifuentes, 15.III.1963 (fl), Molina 11418 (EAP). Gracias a Dios: Ahuas Bila, al SW de Puerto Lempira, río Wankí, 5-13.V.1985 (fl), Nelson E Cruz 9481 (MO, TEFH). Islas de la Bahía: al E de Coxenhole, Isla Roatán, 21.IV.1967 (fl), Molina 20738 (EAP). Olancho: tío Talgua, al SE de Catacamas, 12.V.1987 (fl, fr), Ortega 349 (EAP, TEFH). Santa Bárbara: lago de Yojoa, cerca El Rincón, 7.V.1987 (fl), Blackmore E Chorley 3705 (MO, TEFH). Yoro: alrededor de Santa Rita, 21.IV.1971 (fl), Hernández \& Mancias 1081 (TEFH).

2. Tabernaemontana amygdalifolia Jacq., Enum. Syst. Pl. 14. 1760

Tipo: Cult., Austria, Wien, Hort. Schönbrunn, Herb. Jacquin s.n. (holótipo, W). (Fig. 20 D).

Árboles o arbustos 2-6 m de altura, tallos glabros a glabrescentes. Hojas 4,9-15,1 × 2,1-5,8 cm, elípticas a angostamente obovadas, el ápice corto-acuminado, la base cuneada, glabras, pecíolo 0,7-2,4 cm de largo. Inflorescencia (sub)erecta, con pocas flores, pedicelos 7-19 mm de largo, brácteas ca. $2 \mathrm{~mm}$ de largo; sépalos ca. $2 \mathrm{~mm}$ de largo, ovados; corola blanca, con una anillo amarillo alrededor de la fauce, tubo $12-15 \mathrm{~mm}$ de largo, 1,5-2 mm de diámetro en la fauce, lóbulos de 13-19 mm de largo, angostamente obovados; estambres insertos en la parte superior del tubo, las anteras con más de la mitad de su longitud exerta, anteras ca. $4 \mathrm{~mm}$ de largo, nectario menos de la mitad de la longitud del ovario. Frutos 3-5 × 1-2,3 cm, verdes al madurar, lisos; semillas 6-7 mm de largo.

Distribución. México a Colombia, Venezuela, Ecuador, Perú y Bolivia. Bosques secos y bosques húmedos, en elevaciones de 50-1200 m. Especímenes con flores se han recolectado entre enero y julio.

Nombres comunes. "Chilindrón"; "Cojón de burro"; "Cojón de mico"; "Lechera” (Nelson, 2008).

Es la especie más común en bosques secos, donde se reconoce por sus anteras con al menos la mitad de su longitud exerta y lóbulos distalmente blancos. Como fue mencionado por Morales (2005a), los especímenes de zonas húmedas difieren en varios caracteres de aquellos de zonas secas y es posible que representen dos especies distintas. 


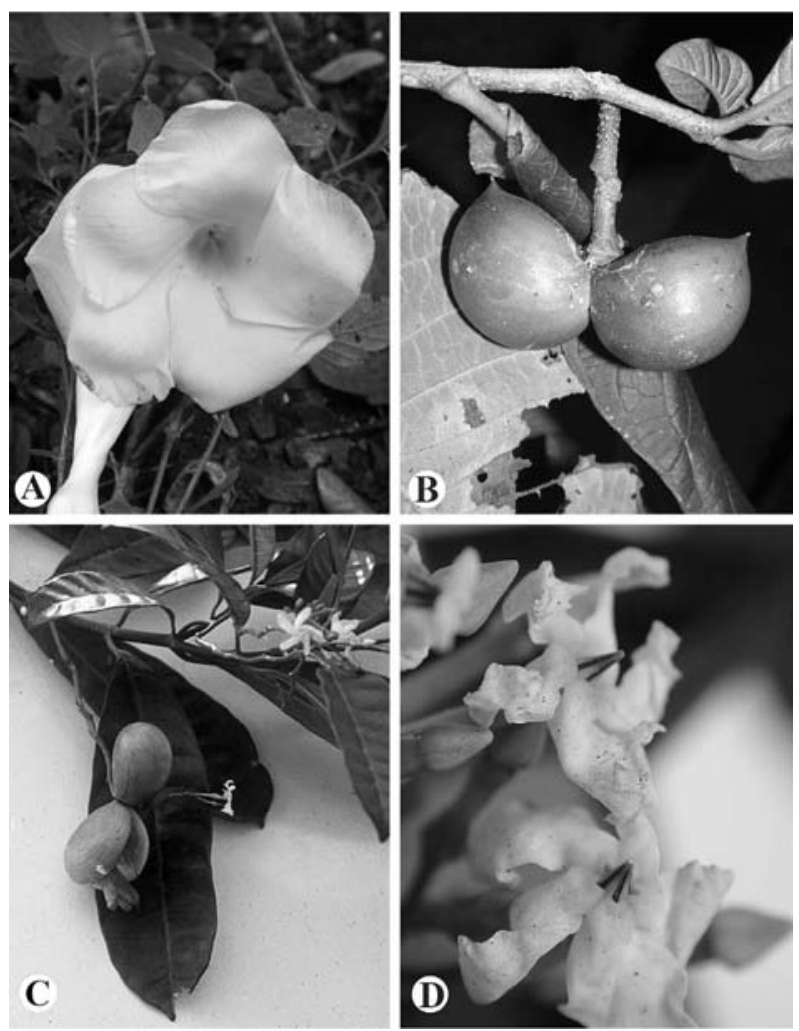

Fig. 20. Stemmadenia y Tabernaemontana. A,B, Stemmadenia pubescens; C, Tabernaemontana alba; D, T. amygdalifolia.

Especímenes representativos examinados. HONDURAS. Choluteca: al S de El Triunfo, 20.VI.1974 (fl), Repulski 396 (EAP). Comayagua: río Humuya, al E de Lejamaní, 15.III.1983 (fl), Holst 940 (EAP, TEFH). El Paraíso: Aldea El Chichicaste, al NE de Danlí, 5.IV.1985 (fl), Sánchez 122 (TEFH). Gracias a Dios: río Patuca, 25.III.1995 (fl), House 2360 (MO). Olancho: río Telica, Juticalpa, 6.IV.1971 (fl), Hernández E Rendón 5392 (TEFH). Santa Bárbara: El Mochito, 23-26.VII.1976 (fl), Vargas 701 (MO). Valle: El Coyolito, Golfo de Fonseca, 7.III.1971 (fl), Molina 25969 (EAP). Yoro: Olanchito, San José, río Agalteca, 2.VII.1994 (fl), Davidse \& al. 35510 (EAP, MO). Valle: isla Zacate Grande, La Guayaba, 1991 (fl), Andino 250 (TEFH).

3. Tabernaemontana arborea Rose, Bot. Gaz. 18(6): 206. 1893

Peschiera arborea (Rose) Markgr., Notizbl. Bot. Gart. Berlin-Dahlem 14(122): 173. 1938

Tipo: Guatemala. Quezaltenango: río Ocosito, IV.1892 (fl), Donnell-Smith 2766 (holótipo, US; isótipos, F [fotografía F neg. 67927], G, GH, K, M, MO, NY, P, UPS). (Fig. 21 A).

Tabernaemontana schippii Standl., Publ. Field. Columbian Mus., Bot. Ser. 8(1): 34. 1930

Tipo: Belice: Big creek, 20.IV.1929 (fl), Schipp 168 (holótipo, F [foto F neg. 50823], isótipos, BM, G, GH, K, MO, NY, UC, US).
Árboles 4-13 m de altura, tallos glabros. Hojas 4,8$15,5 \times 2,1-5,7 \mathrm{~cm}$, elípticas, el ápice acuminado, la base obtusas, glabras, pecíolo $0,4-1,7 \mathrm{~cm}$ de largo. Inflorescencia erecta, con muchas flores, pedicelos $0,7-1 \mathrm{~cm}$ de largo, brácteas ca. $1 \mathrm{~mm}$ de largo; sépalos 1-2 mm de largo, ovados; corola blanca, tubo 5-8 mm de largo, ca. 1,5 $\mathrm{mm}$ de diámetro en la fauce, lóbulos $0,8-1,4 \mathrm{~cm}$ de largo, angostamente obovados; estambres insertos en la base del tubo, anteras 2-3 mm de largo, incluidas, nectario inconspicuo. Frutos 4-5,5 × 2,9-3,4 cm, canela-café o grisáceos al madurar; semillas 0,8-1,1 cm de largo.

Distribución. México a Colombia. Bosques muy húmedos, en elevaciones de 0-400 m. Floración entre abril y diciembre.

Nombres comunes. "Cojón de caballo" (Comayagua); "Cojón de mico" (Atlántida). Nelson (2008) reporta los siguientes nombres: "Buksa mahbra" (mískito, cojón de jagüilla); "Cachito"; "Chivo"; "Cojón de burro"; "Cojón de potro"; "Huevo de toro"; "Muku" (tawahka); "Quiebramuela"; "Young girl's booby" (inglés).

Tabernaemontana arborea se puede distinguir del resto de especies del género en Honduras por la posición de inserción de sus estambres, ya que estos se encuentran insertos en la base del tubo, en contraposición con el resto, que se encuentran insertos cerca del medio o en el tercio distal.

Especímenes representativos examinados. HONDURAS. Atlántida: Jardín Botánico de Lancetilla, 14.IV.1994 (fl), Nelson E Andino 18036 (TEFH) Comayagua: río Jaitique, Taulabe y San José de Comayagua, 18.IV.1974 (fl), Hazlett 1469 (EAP, TEFH). Cortés: San José, al SE de San Pedro, 20.IV.1956 (fl), Molina 6757 (EAP); cercanías de La Lima, 11-20.IV.1947 (fl), Standley E Chacón 7246 (EAP, MO). Gracias a Dios: río Platano, 23.V.1973 (fr), Gentry \& al. 7516 (MO, TEFH). Yoro: entre Tela y La Ceiba, La Masica, 27.IV.2000 (fl), Daniel \& Araque 9506 (EAP, MO).

4. Tabernaemontana divaricata (L.) R. Br. ex Roem. \& Schult., Syst. Veg. 4: 427. 1819

Nerium divaricatumL. Sp. Pl. 1: 209. 1753

Ervatamia divaricata (L.) Burkill, Rec. Bot. Surv. India 10(2): 320.1925

Tipo: Habitat in India, sin fecha (fl), Herb. Hermann 1: 7, No. 109 (lectótipo, designado por Leeuwenberg (1984), BM). (Fig. 21 B).

Arbustos 1-2,5 m de altura, tallos glabros. Hojas 5,2-14,2 × 1,9-6,1 cm, elípticas, el ápice acuminado, la base cuneada, glabras, pecíolo 0,4-1,1 cm de largo. Inflorescencia erecta, pedicelos $0,8-2,1 \mathrm{~cm}$ de largo, brácteas 2-3 $\mathrm{mm}$ de largo; sépalos 3-4 $\mathrm{mm}$ de largo, ovados; corola blanca, generalmente con doble serie de lóbulos, tubo 1,7-2,7 cm de largo, abultado en la posición de los estambres, 4-6 mm de diámetro en la fauce, lóbulos de 1,9-3,2 cm de largo, obovados; es- 
tambres insertos en la mitad del tubo, anteras 4-6 mm de largo, incluidas, generalmente atrofiadas y deformadas (en plantas cultivadas). Frutos no examinados.

Distribución. Originaria de India, se encuentra cultivada en todo el país, en elevaciones entre 200 y 1200 m. Flores se producen durante todo el año.

Nombres comunes. "Coronaria" (El Paraíso); "Falsa gardenia" (Francisco Morazán); "Magnolia" (El Paraíso, Olancho). Otros nombres reportados por Nelson (2008) son "Huevo de toro"y "Magnolia".

Tabernaemontana divaricata se ha cultivado ampliamente en zonas tropicales y subtropicales y se conocen distintas variedades, desde aquellas con una sola serie de lóbulos, hasta aquellas con múltiples series. Hasta el momento, no he observado una planta que produzca frutos.

Especímenes representativos examinados. HONDURAS. Atlántico: Jardín Botánico de Lancetilla, 28.XII.1993 (fl), Nelson \& Andino 17099 (MO, TEFH). El Paraíso: drenaje del río Yeguare, 20.II.1950 (fl), Williams 17158 (EAP). Francisco Morazán: colonia El Country, Comayagüela, 26.VII.1997 (fl), Molina E Molina 34560 (EAP). Gracias a Dios: Puerto Lempira, laguna Caratasca, 5-8.IX.1978 (fl), Nelson 4840 (TEFH). Olancho: Aldea de Cayo Blanco, al SE de Juticalpa, 29.I.1985 (fl), Alvarado123 (TEFH). Santa Bárbara: Trinidad, 13.X.1990 (fl), Sagastume 74 (EAP).

26. Thenardia Kunth, Nov. Gen. Sp. (quarto ed.) 3: 209, t. 240. 1818 [1819]

Lianas, tallos con secreción acuosa, glabros o puberulentos, coléteres interpeciolares inconspicuos. Hojas opuestas, eglandulares, láminas glabras o pubescentes, pecioladas. Inflorescencias cimas subumbeliformes, axilares, con pocas a muchas flores, brácteas escamiformes; cáliz con 5 sépalos, similares, pequeños y más o menos triangulares, con 1 coléter en la base de la cara adaxial; corola rotada, blanco-crema a vino, sin estructuras coronales, limbo con 5 lóbulos, estivación dextrorsa; estambres exsertos, anteras conniventes y aglutinadas a la cabeza estigmática, con el ápice acuminado, gineceo bicarpelar, sincárpico, cabeza estigmática fusiforme con un anillo membranoso basal; nectarios 5, separados. Frutos folículos sincárpicos, moniliformes, unidos longitudinalmente, membranáceos; semillas pocas, truncadas, y comosas en el ápice micropilar.

Género con 3 especies restringidas principalmente a México, con una sola presente en Honduras (Williams, 1995, 1998).

1. Thenardia chiapensis J. Williams, Brittonia 47: 403, f. 1-3. 1995

Tipo: México. Chiapas: Mahosik, 8.VIII.1966 (fl), Breedlove 14837 (holótipo, TEX; isótipos, F, MEXU, NY).
Lianas, tallos glabros. Hojas con la lámina 6,5-10,2 $\times 0,7-1,5 \mathrm{~cm}$, angostamente elípticas, el ápice acuminado, la base cuneada, glabra, pecíolo 9-20 mm de largo. Inflorescencia con pocas flores, pedicelos 6-7,5 $\mathrm{mm}$ de largo, brácteas 1,5-2,3 mm de largo, lineares; sépalos 1,1-2,2 mm de largo, ovados; corola blanca, tubo 1-2 mm de largo, con un diámetro $2-3 \mathrm{~mm}$ en la fauce, lóbulos 2-3,2 × 1-1,3 cm, suberectos; anteras 2,5-3 mm de largo, nectarios ligeramente más cortos que el ovario. Folículos de 14-20,4 × 0,2-0,3 cm; semillas 8-14 mm de largo, coma 0,9-1,5 cm de largo.

Distribución. S de México (Estado de Chiapas) y Honduras. Bosques húmedos en elevaciones de 1400 m. Especímenes con flores se han recolectado en febrero.

Thenardia chiapensis fue descrita por Williams (1995) en forma relativamente reciente y era considerada endémica de México. La presencia de este género en Honduras es bastante notable por ser la única especie conocida hasta el momento fuera de México y el primer registro del mismo para Mesoamérica. Thenardia se encuentra cercanamente relacionado a Thoreauea, otro género de las Echiteae endémico de México, pero que se separa por la presencia de una corona anular alrededor de la fauce (Morales, 2005c).

Especimen representativo examinado. HONDURAS. La Paz: La Florida de Marcala, 24.II.1986 (fr), Keyser 1163 (EAP).

\section{Thevetia L., Opera Var. (Syst. Nat. Ed. 8) 212. 1758}

Arbustos o árboles, tallos con secreción lechosa, glabros a puberulentos, los pecíolos con coléteres axilares inconspicuos. Hojas alternas, espiraladas, eglandulares, glabras o puberulentas en la superficie abaxial, membranáceas sésiles, subsésiles a pecioladas. Inflorescencias cimosas, axilares a subterminales, con pocas o muchas flores, glabrescentes, brácteas escariosas; caliz con 5 sépalos, similares, escariosos a subfoliáceos, con numerosos coléteres en la base; corola hipocraterimorfa, crema a verde-crema, sin corona anular, e manera usual glabra, el interior con cinco lóbulos coronales en forma opuesta sobre cada antera, limbo con 5 lóbulos, con estivación sinistrorsa; estambres incluidos, anteras no conniventes ni aglutinadas a la cabeza estigmática, cabeza estigmática con lóbulos basales; gineceo bicarpelar, apocárpico, con 2-4 óvulos, nectario lobulado. Frutos drupas sincárpicas, el exocarpo carnoso o esponjoso, el mesocarpo apenas subleñoso; semillas 2-4, desnudas, no comosas.

Género con 3 especies distribuidas desde México a Colombia y Venezuela y en la región austral de Su- 
damérica, 1 sola especie en Honduras (Alvarado-Cárdenas \& Ochoterena, 2007).

1. Thevetia ahouai (L.) A. DC., Prodr. 8: 345. 1844 Cerbera ahouai L., Sp. Pl. 1: 208. 1753

Plumeriopsis ahouai (L.) Rusby \& Woodson, Ann. Missouri Bot. Gard. 24 (1): 11. 1937

Tipo: Habitat in Brasilia, sin fecha (fl, fr), Herb. Clifford: 76, Plumeria 1, rama, fruto y flor inferior derecha (lectótipo, designado por Leeuwenberg (1993), BM). (Fig. 6 D, 21 C-D).

Arbusto 1,5-4 m de altura, tallos glabros. Hojas con láminas 7,4-22,8 × 4,4-8,9 cm, obovadas a angostamente elípticas, el ápice agudo o cortamente acuminado, la base cuneada, glabras, pecíolo 4-15 mm de largo. Inflorescencia con 5-10 flores, pedicelos 1-1,8 cm de largo, brácteas ca. $1 \mathrm{~mm}$ de largo; sépalos 3-7 mm de largo, ovados; corola hipocraterimorfa, tubo 1,53,1 cm de largo, 4-5 mm de diámetro en la fauce, lóbulos de 1,3-2,4 cm, obovados; estambres insertos cerca de la fauce del tubo, anteras ca. $2 \mathrm{~mm}$ de largo, nectario ca. la mitad de la longitud del ovario, (sub)entero. Frutos 3,3-4,3 cm de diámetro, rojos al madurar, semillas de 2-2,3 cm de diámetro.

Distribución. México a Colombia y Venezuela. Bosques muy húmedos, en elevaciones entre 0-600(-800) $\mathrm{m}$. Flores y frutos son producidos durante todo el año.

Nombres comunes. "Chilindrón" (Atlántida, Olancho); "Codo de Fraile" (Cortes); "Huevo de gato" (Cortes); "Lechoso" (Atlántida); "Manzana de perro" (Atlántida); "Paloni berry" (Islas de la Bahia). Nelson reporta los siguientes nombres: "Buksa makalaya" (mískito); "Chilca”, "Codo de monje”, "Huevo de burro", "Quiebramuela” y “young girl's booby” (inglés).

Thevetia abouai se puede distinguir con facilidad de las especies de Cascabela por su corola hipocraterimorfa, de color crema o verde-crema y frutos rojo intenso al madurar. Adicionalmente, esta especie crece en forma natural principalmente en bosques muy húmedos, mientras que en el resto de las especies de Cascabela presentes en Honduras crece en bosques mucho más secos. También se ha utilizado como ornamental debido a su atractivo color y la numerosa cantidad de frutos que produce.

Especímenes representativos examinados. HONDURAS. Atlántida: Lancetilla, cerca de Tela, San Francisco, 8.XI.1988 (fr), MacDougal \& al. 3355 (MO, TEFH). Colón: Trujillo, cerro Calentura, 29.IX.1989 (fr), Nelson \& Andino 10825 (TEFH). Comayagua: Montañuelas, 21.VIII.1981 (fr), Lentz 845 (TEFH). Cortes: entre Villa Nueva y Pimienta, camino a San Pedro Sula, 22.VI.1991 (fl), Molina E Molina 34435 (EAP, MO). Francisco Morazán: El Zamorano, 30.III.1986 (fl), Molina 33913 (EAP, MO). Gracias de Dios: río Plátano, 17-23.V.1973 (fl), Clewell E Cruz 4125 (EAP, MO, TEFH). Islas de la Bahía: Isla Guanaja, 20.VIII.1954 (fl, fr),
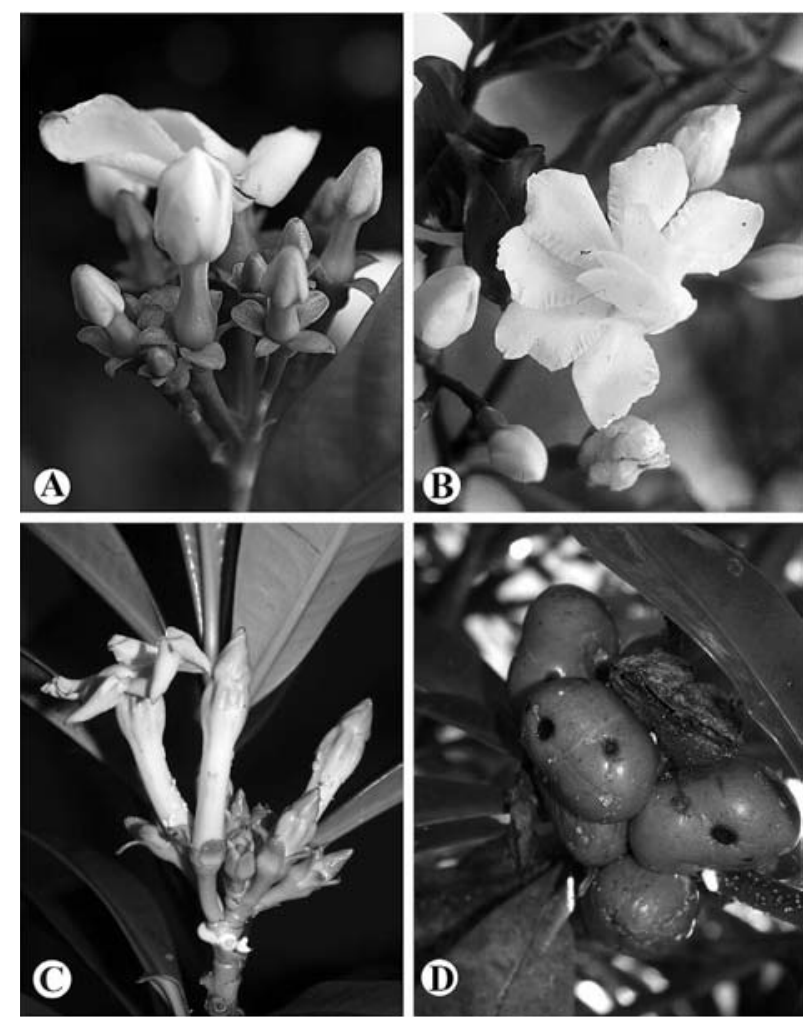

Fig. 21. Tabernaemontana y Thevetia. A, Tabernaemontana arborea; B, T. divaricada; C,D, Thevetia ahoaui.

Johannessen 527 (EAP). Olancho: al SE de Catacamas, Escuela Nacional de Agricultura, 1.IV.1987 (fr), Ortega 235 (EAP, MO, TEFH). Santa Bárbara: río Sesecapa, cercanías de Santa Bárbara, 22.VIII.1968 (fr), Molina 22000 (EAP). Yoro: valle del río Leán, cercanías de Las Lomas, entre San José de Texiguat y Suyapa de Leán, 16.V.1991 (fl), Davidse E al. 34458 (EAP, TEFH).

28. Tintinnabularia Woodson, Ann. Missouri Bot. Gard. 23(2): 387.1936

Lianas, tallos con secreción lechosa, glabros o diminutamente puberulentos, coléteres interpeciolares inconspicuos. Hojas opuestas, con coléteres en la base del nervio central adaxialmente, láminas glabras o glabrescentes, de manera usual con domacios en las axilas de las venas secundarias por el envés, rara vez ausentes, pecioladas. Inflorescencias cimas umbeliformes, terminales o subterminales, con pocas flores, brácteas escamiformes, no foliáceas; cáliz con 5 sépalos, simialres, foliáceos, glabros, con 1 ó 2 coléteres en la base de la cara adaxial; corola infundibuliforme a campanulada, con tonos variegados entre amarillo, crema, verde y rosado, sin estructuras coronales, limbo con 5 lóbulos, estivación dextrorsa; estambres incluidos, anteras conniventes y aglutinadas a la cabeza estigmática, con el ápice acuminado y filiforme; gineceo bicarpelar, apocárpico, cabeza estigmática con 5 
costillas longitudinales; nectarios 5, separados o connados en la base. Frutos folículos apocárpicos, moniliformes, membranáceos; semillas numerosas, truncadas y comosas en el ápice micropilar.

Género con 3 especies en México, Guatemala y Honduras, con 1 sola en Honduras (Morales, 1996b; Williams, 1999).

1. Tintinnabularia murallensis J. Williams, Lundellia 2: 138, f. 1-2. 1999

Tipo: Honduras. Olancho: Parque Nacional La Muralla, al NNO de la Unión, 6.VI.1992 (fl), Hawkins E. Mejía 503 (holótipo, MO [foto, INB]; isótipos, EAP [foto, INB], TEFH [foto, INB]).

Liana, tallos glabros. Hojas con la lámina 5-8,2 × 1 $3,2 \mathrm{~cm}$, angostamente elípticas, ovado-elípticas a angostamente ovadas, 2-4 coléteres en la base del nervio central, el ápice acuminado o caudado-acuminado, la base obtusa o cuneada, pecíolo 5-9 mm de largo. Inflorescencia una cima usualmente con varias umbelas, algunas veces reducidas a una sola umbela, con muchas flores, pedicelos de 8-10 mm de largo, brácteas de 1-1,3 mm de largo; sépalos 1,1-1,3 mm, ovados; corola amarilla, la parte inferior del tubo 7-9 $\mathrm{mm}$ de largo, la parte superior del tubo 5-7 mm de largo, campanulada, de 5-8 mm de diámetro en la fauce, lóbulos 4-5 $\times 3-4 \mathrm{~mm}$, suberectos o algo extendidos; anteras 5,7-6,1 mm de largo, nectarios tan largos como el ovario. Folículos desconocidos.

Distribución. Endémica a Honduras, donde crece en bosques muy húmedos en elevaciones de 1500$1700 \mathrm{~m}$. Especímenes con flores se han recolectado en mayo y junio.

Tintinnabularia murallensis se puede reconocer con facilidad por sus hojas con coléteres en la base del nervio central adaxialmente, con domacios a lo largo del nervio central por el envés y anteras con apéndices apicales filifomes y prolongados.

Especimenes representativos examinados. HONDURAS. Olancho: La Muralla, al NNW de la Unión, 4.VI.1992 (fl), D'Arcy 18117 (EAP, MO). Yoro: valle del río Pijol, al SE del cerro Pajarillos, 28.V.1993 (fl), Evans 1752 (EAP, MO, TEFH).

29. Tonduzia Pittier, Contr. U.S. Natl. Herb. 12(2): 103. 1908

Árboles o arbustos, tallos con secreción lechosa, glabros, coléteres intrapeciolares inconspicuos. Hojas verticiladas a opuestas, en verticilos de 3 ó 4(5), eglandulares, láminas glabras, membranáceas, pecioladas. Inflorescencias corimbosas, subterminales o terminales, con muchas flores, brácteas escamiformes, inconspicuas; cáliz con 5 sépalos, iguales, glabros o puberu- lentos, sin coléteres en la base; corola hipocraterimor$\mathrm{fa}$, sin corona anular o lóbulos coronales libres, crema o blanca, con 5 lóbulos, con estivación sinistrorsa; estambres incluidos, anteras no conniventes ni aglutinadas a la cabeza estigmática, cabeza estigmática con un anillo basal, el ápice fusiforme; gineceo bicarpelar, apocárpico, nectario anular, pentalobulado, o con cinco nectarios individuales. Frutos folículos apocárpicos, continuos, levemente leñosos; semillas numerosas, comprimidas, ciliadas en los márgenes, no comosas.

Género neotropical con 2 especies entre México y Panamá, una sola conocida en Honduras. Este género y sus dos especies han sido tratadas en Alstonia desde Gentry (1983). Sin embargo, Simões \& al. (2007a) después de un análisis cladístico basado en varios marcadores moleculares demostraron que los géneros son entidades distintas. Aquí se sigue el concepto de especies usado por Morales (1995) y no el de Sidiyasa (1998).

1. Tonduzia stenophylla (Donn. Sm.) Pittier, Contr. U.S. Natl. Herb. 12(2): 104, t. 9.1908

Rawvolfia stenophylla Donn. Sm., Bot. Gaz. 44: 115. 1907

Alstonia stenophylla (Donn. Sm) J.F. Morales, Darwiniana 43: 108. 2005, nom. illeg., non A. stenophylla Guillaumin (1941)

Tipo: El Salvador. San Salvador: cercanías de San Salvador, 1905 (fl), Renson 289 (holótipo, US [2 pliegos]; isótipo, F). (Figs. 3 b, 22 A,B).

Tonduzia parvifolia Pittier, Contr. U.S. Natl. Herb. 12(2): 103, f. 5-6. 1908, non Alstonia parvifolia Merr. (1905)

Tipo: Costa Rica. Cartago: Angostura, cerca de Turrialba, 11-IV-1903 (fl), Doyle 33 (holótipo, US; isótipo, MO).

Tonduzia pittieri Donn. Sm., Bot. Gaz. 49(6): 456. 1910

Alstonia pittieri (Donn. Sm.) A.H. Gentry, Ann. Missouri Bot. Gard. 70: 206. 1983

Tipo: Guatemala. Departamento desconocido: Fiscal, 1-VI-1909 (fl), Deam 6098 (lectótipo, designado por Sidiyasa (1998), US [fragmento, EAP]) isolectótipo, F [foto F neg. 56525].

Tonduzia longipedunculata Woodson, Publ. Field Mus. Nat. Hist., Bot. Ser. 23(2): 78. 1944

Tipo: Guatemala. Sololá: sendero entre San Pedro, vía San Juan, San Cristóbal, Buena Vista y falda NW del Volcán Santa Clara, 8.VI.1942 (fl), Steyermark 47313 (holótipo, MO; isótipo, $\mathrm{F}$ [foto F neg. 56526]). 
Árboles o arbustos 2-8 $\mathrm{m}$ de altura, tallos glabros. Hojas con la lámina 3,3-14,8 × 0,7-2,1 cm, angostamente elípticas a linear-elípticas, el ápice agudo o acuminado, la base cuneada, pecíolo 5-20 mm de largo. Inflorescencia con pedicelos $2-5 \mathrm{~mm}$ de largo, brácteas ca. $1 \mathrm{~mm}$ de largo; sépalos ca. $1 \mathrm{~mm}$ de largo, ovados; corola blanca, tubo 4-6 mm de largo, lóbulos angostamente obovados, 3-6 × 1-1,5 mm; anteras ca. 1 $\mathrm{mm}$ de largo, nectario mucho más corto que el ovario, inconspicuo. Folículos 7,8-14,1 × 0,3-0,5 cm; semillas 1-1,2 cm de largo.

Distribución. México a Costa Rica. Bosques húmedos, en elevaciones de 1300-1600 m. Especímenes con flores han sido recolectados de marzo a mayo.

Tonduzia stenopbylla se puede reconocer por sus hojas verticiladas, flores blancas, con el tubo de la corola de 4-6 mm de largo y frutos foliculares, con las semillas ciliadas marginalmente y careciendo de coma en sus estremos. En Mesoamérica, otros géneros nativos con hojas dispuestas en verticilos solo incluyen a Couma (no registrado aún en Honduras, pero que es de esperarse), el cual se puede diferenciar por su hábito arbóreo más desarrollado, hojas mucho más grandes, flores rosadas y frutos abayados, así como a Rauvolfia, que se separa por sus hojas anisófilas, corolas con el tubo pequeño y diminuto y frutos drupáceos.

Especímenes representativos examinados. HONDURAS. Comayagua: quebrada El Destiladero, al N de Zambrano, 25.X-1.XI.1991 (st), Nelson E Andino 13083 (TEFH). Cortés: montaña San Idalfonso, cerca de Bañaderos, 26.III.1963 (fl), Molina 11465 (EAP).

30. Vallesia Ruiz \& Pav., Fl. Peruv. Prodr. 2: 26. 1799

Arbustos o arbolitos, tallos con secreción acuosa o acuoso-lechosa, glabros a pubescentes, coléteres interpeciolares inconspicuos. Hojas alternas, la lámina eglandular, glabras o pubescentes, pecioladas. Inflorescencias umbeliformes a cimoso-umbeliformes, axilares, con pocas o muchas flores, brácteas escariosas e inconspicuas; cáliz con 5 sépalos, similares, escamiformes, sin coléteres en la base; corola hipocrateriforma, sin corona anular o apéndices coronales libres, blancas, crema o amarillentas, limbo con 5 lóbulos, con estivación sinistrorsa; estambres incluidos, las anteras no conniventes ni aglutinadas a la cabeza estigmática, cabeza estigmática subcilíndrica, sin un anillo basal; ovario apocárpico, gineceo bicarpelar, nectario ausente. Frutos drupas apocárpicas (usualmente con sólo un carpelo desarrollado por aborción), carnosos y jugosos, con varias semillas desnudas, no comosas.

Género con ca. de 9 especies distribuidas desde México y las Antillas a Costa Rica (excepto Nicaragua) y desde Colombia e Islas Galápagos al N de Argentina, una en Honduras. (Meyer, 1955; Morales, 1998c).
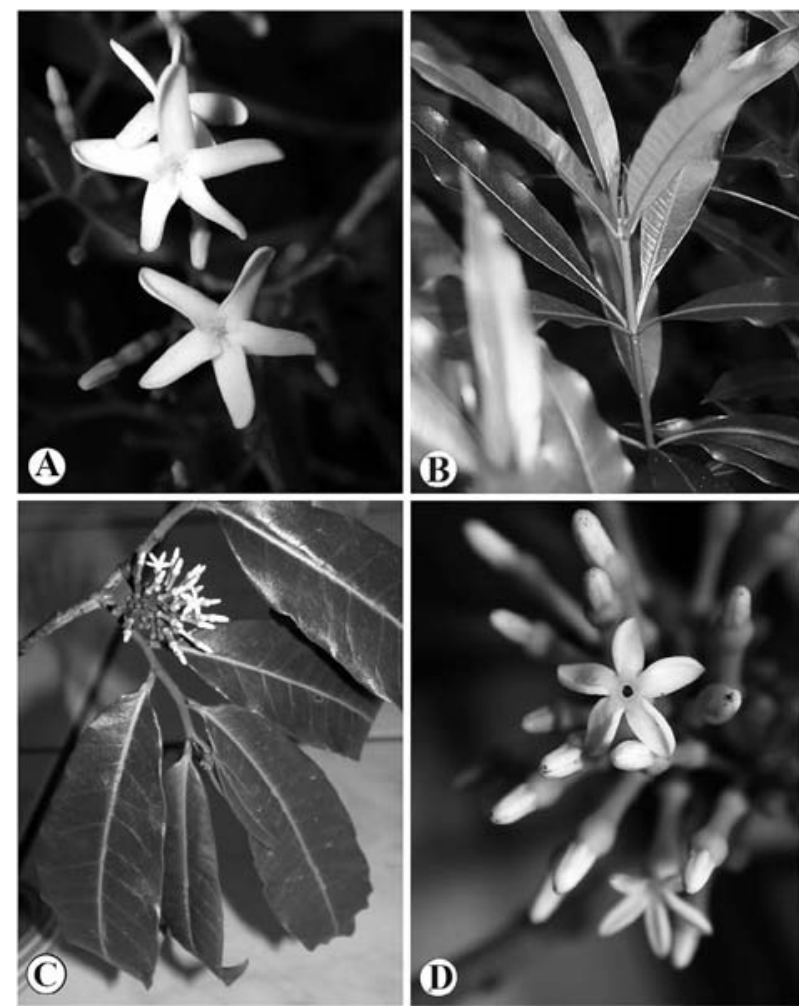

Fig. 22. Tonduzia y Vallesia. A,B, T. stenophylla; C,D, V. aurantiaca.

1. Vallesia aurantiaca (M. Martens \& Galeotti) J.F. Morales, Novon 8(3): 263. 1998

Neriandra aurantiaca M. Martens \& Galeotti, Bull. Acad. Roy. Sci. Bruxelles 11(6): 356. 1844.

Tipo: México. Veracruz: Santiago de Huatusco, IV.1841 (fl), Galeotti 1591 (holótipo, BR). (Fig. 22 C,D).

Vallesia mexicana Müll. Arg., Linnaea 30: 393. 1860

Tipo: México. Veracruz: cerca de Orizaba, II.1854, M. Botteri 473 (holótipo, G-DC; isótipos, CGE, P [foto, INB]).

Árboles o arbustos de 2-6 m de altura, ramas glabras. Hojas con láminas 6,2-16,6 × 1,6-4,8 cm, elípticas, el ápice acuminado, la base obtusas, glabras, pecíolo 0,4-0,9 cm de largo. Inflorescencia con muchas flores, pedicelos 2-3 mm de largo, brácteas ca. 1 $\mathrm{mm}$ de largo; sépalos ca. $2 \mathrm{~mm}$ de largo, ovados; corola blanca o crema, tubo 6-9 $\mathrm{mm}$ de largo, ca. 1,5 mm de diámetro en la fauce, dilatado en la inserción de los estambres, lóbulos 4-5 × 1,5-2 mm, angostamente ovados; anteras ca. 1,5 mm de largo, ovario ca. $1,5 \mathrm{~mm}$ de largo. Frutos 1,5-3 × 0,5-0,8 cm, blancos al madurar; semillas 1,3-2,6 cm de largo.

Distribución. México, Guatemala, Belice, Hondu- 
ras y Costa Rica. Bosques muy húmedos, entre los 1800 y 2000 m. Floración y fructificación en enero.

Vallesia aurantiaca se reconoce fácilmente por sus hojas alternas y disposición más o menos dística. En forma general, es una especie poco recolectada en todo el rango de distribución, y de Honduras se conoce sólo de la colección citada abajo.

Espécimen representativo examinado. HONDURAS. Lempira: quebrada Naranjo, al SE de Gracias, 29.I.1992 (fl, fr), Hawkins 144 (EAP, MO, TEFH).

\section{Agradecimientos}

Quedo agradecido a los conservadores de A, B, BEREA, BM, BR, C, CGE, COL, CR, DUKE, EAP, ENCB, F, F, FI, FI-W, G, GH, HAL, HUA, K, LAGU, LD, LE, LIL, M, MA, MEXU, MICH, MO, NY, O, P, PMA, S, U, UPS, US, USJ, UVAL, W, WAG, VALLE y Z. Cyrilo Nelson (TEFH) brindó múltiples facilidades para la visita del herbario TEFH en Tegucigalpa y muy amablemente proporcionó una lista de nombres comunes de su trabajo inédito del listado de las plantas de Honduras. Barry Hammel (MO) tradujo el resumen al inglés. Agradezco a las siguientes personas autorizar el uso de las respectivas fotografías aquí mencionadas: Reinaldo Aguilar (Aspidosperma megalocarpon, A. desmanthun), Tom Croat (Odontadenia puncticulosa), Robin Foster (Echites umbellatus), Al Gentry (Anechites nerium, usada con autorización del Missouri Botanical Garden), James Manhart (Carissa macrocarpa), Ana Luc McVean (Prestonia longifolia), Alexander Rodríguez (Tonduzia pittieri, Malouetia guatemalensis) y Forest \& Kim Starr (Plumeria obtusa).

\section{Referencias bibliográficas}

Allorge-Boiteau, L. 1998. New combinations in Odontadenia and Mandevilla (Apocynaceae). Phytologia 84(4): 304-306.

Alvarado-Cárdenas, L. 2007. Stemmadenia oaxacana AlvaradoCárdenas (Apocynaceae), una nueva especie para el Estado de Oaxaca, México. Candollea 62: 189-192.

Alvarado-Cárdenas, L. \& Ochoterena, H. 2007. A phylogenetic análisis of the Cascabela-Thevetia complex (Plumerieae; Apocynaceae) based on morphology. Annals of the Missouri Botanical Garden 94: 298-323.

Bergen, M.A. van. 1996. Revision of Catharanthus G. Don. Series of Revisions of Apocynaceae XLI. Agric. Univ. Wageningen Pap. 96: 9-46.

Codd, L.E. 1963. Apocynaceae. Pp. 244-296. In: Codd, L.E. \& Rycroft, H.B. (eds.), Flora of Southern Africa. Vol. 26. Pretoria: Dept. Agric. Techn. Serv. [Republ. S. Africa]. 307 pp.

Dandy, J.E. 1958. The Sloane Herbarium. British Museum (Natural History), London, England. 246 pp.

Endress, M.E. \& Bruyns, P. 2000. A revised classification of the Apocynaceae s.l. Botanical Review (Lancaster) 66: 1-56.

Ezcurra, C. 1981. Revisión de las Apocináceas de la Argentina. Darwiniana 23: 367-474.

Fallen, M.E. 1983. A systematic revision of Anechites (Apocynaceae). Brittonia 25: 222-231.

Gentry, A. 1983. Alstonia (Apocynaceae): another paleotropical genus in Central America.

Gentry, A. 2001. Apocynaceae. In: Stevens, W., Ulloa, C., Pool, A. \& Montiel, O. (eds.), Flora de Nicaragua. Monographs in Systematic Botany from the Missouri Botanical Garden 85(1): 116-132.

Gutiérrez, J. \& Linares, J. 2006. A new species of Plumeria (Apocynaceae) from Honduras and Salvador: Plumeria mariaelenae. International Cactus Adventures 69: 2-9.
Hansen, B.F. 1985. A monographic revision of Forsteronia (Apocynaceae). Ph.D. dissertation. University of South Florida. USA. [University Microfilms International, Ann. Arbor.].

Hansen, B.F. \& Wunderlin, R.P. 1986. Pentalinon Voigt, an earlier name for Urechites Müll. Arg. (Apocynaceae). Taxon 35(1): 166-168.

Hansen, B.F. \& Morales, J.F. 2009. Lectotypifications in the genera Forsteronia and Laxoplumeria (Apocynaceae). Darwiniana 47. 70: 206-207.

Holmgren, P.K., Holmgren, N.H. \& Barnett, L.C. 1990. Index Herbariorum. Part I: The Herbaria of the World. New York Botanical Garden, New York, USA.

Leeuwenberg, A.J.M. 1984. Tabernaemontana L. (Apocynaceae): A review of its taxonomy, phytochemistry, ethnobotany and pharmacology. In: Van Beek, T., Verpoorte, R., Baeheim, A., Leeuwenberg, A. \& Bisset, N. (eds.), Journal of Ethnopharmacology 10(1): 1-156.

Leeuwenberg, A.J.M. 1993. In: Jarvis, C.E., Barrie, F.R., Allan, D.M. \& Reveal, J.L. (eds.), A list of Linnaean generic names and their types. Regnum Vegabile 127: 1-100.

Leeuwenberg, A.J.M. 1994. A revision of Tabernaemontana Two. The New World species and Stemmadenia. Royal Botanic Gardens, Kew, U.K. 213-450.

Livshultz, T., Middleton, D., Endress, M. \& Williams, J.K. 2007. Phylogeny of Apocynoideae and the Apsa clade (Apocynaceae s.1.). Annals of the Missouri Botanical Garden 94: 324-359.

Marcondes-Ferreira, W. 1988. Aspidosperma Mart., nom. cons. (Apocynaceae): estudos taxonômicos. $\mathrm{Ph} \mathrm{D}$. thesis, Universidade Estadual de Campinas, Brasil.

Meyer, E. 1955. The genus Vallesia, A systematic study.Masters's Thesis, Washington University, St. Louis, Missouri. 1-46 [University Microfilms International, Ann. Arbor.].

Molina R., A. 1975. Enumeración de las plantas de Honduras. Ceiba 19(1): 1-118.

Molina R., A. 1977. Nuevas contribuciones a la flora de Honduras. Ceiba 21(2): 61-66.

Molina R., A. 1984. New records of flowering plants for Honduras. Ceiba 25(2): 127-133.

Monachino, J. 1944. A revision of Lacmellea and the transfer of Zschokkea (Apocynaceae). Lloydia 7: 275-302.

Morales, J.F. 1995. Evaluación del género Alstonia (Apocynaceae) en Centro América. Phytologia 78(3): 192-194.

Morales, J.F. 1996a. Novelties in Prestonia (Apocynaceae). Novon 6(3): 285-287.

Morales, J.F. 1996b. Una nueva especie de Tintinnabularia (Apocynaceae). Novon 6(4): 392-394.

Morales, J.F. 1997a. A synopsis of the genus Allomarkgrafia (Apocynaceae). Brittonia 49:337-345.

Morales, J.F. 1997b. A reevaluation of Echites and Prestonia section Coalitae (Apocynaceae). Brittonia 49(3): 328-336.

Morales, J.F. 1997c [1998]. A synopsis of the genus Macropharynx (Apocynaceae). Rhodora 99: 58-68.

Morales, J.F. 1997d. A synopsis of the genus Prestonia (Apocynaceae) section Tomentosae in Mesoamerica. Novon 7(1): 59-66.

Morales, J.F. 1998a. Synopsis del género Lacmellea (Apocynaceae) en Mesoamérica, con una nueva especie de Costa Rica. Novon 8: 259-262.

Morales, J.F. 1998b. A synopsis of the genus Mandevilla (Apocynaceae) in Mexico and Central America. Brittonia 50(2): 214 233.

Morales, J.F. 1998c. Three new species and a new combination in Vallesia (Apocynaceae). Novon 8: 263-264

Morales, J.F. 1999. A synopsis of the genus Odontadenia (Apocynaceae). In: Leeuwenberg, A.J.M. (ed.), Series of revisions of Apocynaceae XLV. Bulletin du Jardin botanique national de Belgique. 67: 381-477. 
Morales, J.F. 2002. Studies in Neotropical Apocynaceae II: A revision of the genus Fernaldia. Rhodora 104: 186-200

Morales, J.F. 2005a. Estudios en las Apocynaceae Neotropicales XIX: la familia Apocynaceae s. str. (Apocynoideae y Rauvolfioideae) de Costa Rica. Darwiniana 43: 90-191.

Morales, J.F. 2005b. Estudios en las Apocynaceae Neotropicales XIV: nuevas lectopificaciones en los géneros Hylaea J.F. Morales y Pentalinon Voigt (Apocynoideae, Echiteae). Lankesteriana 5(2): 159-160.

Morales, J.F. 2005c. Estudios en las Apocynaceae Neotropicales XV: Sinopsis del género Thoreauea (Apocynoideae, Echiteae), con una nueva especie de Veracruz, México. Brittonia 57(3): 258-263.

Morales, J.F. 2006a. Estudios en las Apocynaceae Neotropicales XXVIII: la familia Apocynaceae (Apocynoideae, Rauvolfioideae) de El Salvador, Centroamérica. Darwiniana 44: 453-489.

Morales, J.F. 2006b. Estudios en las Apocynaceae Neotropicales XXVI: Una monografía del género Mesechites (Apocynoideae, Mesechiteae). Candollea 61(1): 215-277.

Morales, J.F. 2007. Estudios en las Apocynaceae Neotropicales XXXI: el complejo de Mandevilla hirsuta y cuatro nuevas especies. Journal of the Botanical Research Institute of Texas 1(2): 859-869.

Morales, J.F. 2008. Estudios en las Apocynaceae Neotropicales XXXIV: una nueva especie de Echites (Apocynoideae, Echiteae) para Costa Rica. Rodriguésia 59: 197-200.

Morales, J.F. \& Méndez, M. 2005. Estudios en las Apocynaceae Neotropicales XXII: Nuevos realineamientos taxonómicos en el género Stemmadenia (Apocynaceae, Rauvolfioideae, Tabernaemontaneae. Candollea 60(2): 345-371.

Morales, J.F. \& Williams, J. 2004. Allotoonia, a new neotropical genus of Apocynaceae based on a subgeneric segregate of Echites. Sida 21(1): 133-158.

Morales, J.F. \& Williams, J. 2005. Una nueva combinación en el género Allotoonia (Apocynaceae, Apocynoideae, Echiteae). Lankesteriana 5(2): 119-120.

Morton, J., Álvarez, E. \& Quiñónez, C. 1990. Loroco, Fernaldia pandurata (A. DC.) Woodson (Apocynaceae): A popular edible flower of Central America. Economic Botany 44: 301-310.

Nelson, C. 1976. Plantas nuevas para la Flora de Honduras. Ceiba 20(2): 58-68.

Nelson, C. 1977. Plantas Nuevas para la Flora de Honduras. Ceiba 21(1):51-55

Nelson, C. 1979. Plantas nuevas para la Flora de Honduras. III. Ceiba 23(2): 85-92.

Nelson, C. 1986. Plantas comunes de Honduras. Tegucigalpa: Editorial Universitaria, Tegucigalpa, Honduras.

Nelson, C. 1996. La flora de Honduras en la Biología CentraliAmericana, de Hemsley. Fontqueria 44: 53-68.

Nelson, C. 2008. Catálogo de las plantas vasculares de Honduras Espermatofitas. Editorial Guaymuras. Tegucigalpa, Honduras. $1576 \mathrm{pp}$.

Nowicke, J. 1970. Apocynaceae. In: Woodson, R.E., Schery, R. \& al. (eds.), Flora of Panama, Part IV. Annals of the Missouri Botanical Garden 57: 59-130.

Pagen, F.J. 1987. Oleanders. Nerium L. and the oleander cultivars. In: Leeuwenberg, A.J.M. (ed.), Series of Revisions of Apocynaceae, Part XX. Agricultural University Wageningen papers 87: 1-113.

Pineda, N. 1997. Geografía de Honduras. Tercera edición. Editorial Guimuras, Tegucigalpa, Honduras.

Rao, A.S. 1956. A revision of Rauvolfia with particular reference to the American species. Annals of the Missouri Botanical Garden 43: 253-355.

Rudjiman, 1986. A revision de Beaumontia Wallich, Kibatalia G. Don y Vallariopsis Woodson (Apocynaceae). In: Leeuwenberg,
A.J.M (ed.), Series de Revisions de Apocynaceae, Part XIX. Agricultural University Wageningen papers 85: 1-99.

Sakane, M. \& Sheperd, G.J. 1987. Uma revisao do genero Allamanda L. (Apocynaceae). Revista brasileira de botânica 9: 125-149.

Sidiyasa, K. 1998. Taxonomy, phylogeny and wood anatomy of Alstonia (Apocynaceae). Blumea, Suppl. 11: 1-230.

Simões, A.O. \& Kinoshita, L.S. 2002. The Apocynaceae s. str. of the Carrancas region, Minas Gerais, Brazil. Darwiniana 40: 127-169.

Simões, A.O., Endress, M., Van der Niet, T., Kinoshita, L.S. \& Conti, E. 2004. Tribal and intergeneric relationships of Mesechiteae (Apocynoideae, Apocynaceae): evidence from three noncoding pastid DNA regions and morphology. American Journal of Botany 1(9): 1409-1418.

Simões, A.O., Endress, M., Van der Niet, T., Kinoshita, L.S. \& Conti, E. 2006. Is Mandevilla (Apocynaceae, Mesechiteae) monophyletic? Evidence from five plastid DNA loci and morphology. Annals of the Missouri Botanical Garden 93(4): 565-591.

Simões, A.O., Livshultz, T., Conti, E. \& Endress M.E. 2007a. Phylogeny and systematics of the Rauvolfioideae (Apocynaceae) based on molecular and morphological evidence. Annals of the Missouri Botanical Garden 94: 268-297.

Simões, A.O., Kinoshita, L.S. \& Endress, M.E. 2007b. New combinations in Mandevilla Lindley (Apocynaceae). Novon 17(1): 87-90.

Standley, P.C. \& Williams, L.O. 1969. Apocynaceae. In: Standley, P.C. \& Williams, L.O. (eds.), Flora of Guatemala, part VIII, number 4. Fieldiana, Botany 24(8/4): 334-407.

Stearn, W.T. 1957. An introduction to the 'Species Plantarum' and cognate botanical works of Carl Linnaeus (Prefixed to Ray Society facsimile of Linnaeus, Species Plantarum, vol. 1). London, England.

Stearn, W.T. 1978. Nerium L. P. 159. In: Davis, P. (ed.), Flora of Turkey and the East Aegean Islands Vol. 6. Edinburgh, U.K.: Edinburgh Univ. Press. 825 pp.

Wijnands, D.O. 1983. The Botany of the Commelins. A.A. Balkema, Rotterdam, Netherlands. 1-232.

Williams, J.K. 1995. A new species of Thenardia (Apocynaceae, Apocynoideae) from Chiapas, Mexico, with notes on the genus. Brittonia 47(4): 403-407.

Williams, J.K. 1998. A revision of Thenardia H.B.K. (Apocynaceae, Apocynoideae). Lundellia 1: 78-94.

Williams, J.K. 1999. A new species of Tintinnabularia (Apocynaceae, Apocynoideae) from Honduras, with taxonomic notes. Lundellia 2: 136-141.

Woodson, R.E. 1928. Studies in the Apocynaceae II. A revision of the genus Stemmadenia. Annals of the Missouri Botanical Garden 15:341-379

Woodson, R.E. 1933. Studies en the Apocynaceae IV. The American genera of Echitoideae. Annals of the Missouri Botanical Garden 20: 605-790.

Woodson, R.E. 1935. Studies in the Apocynaceae. IV. The American genera of Echitoideae. Annals of the Missouri Botanical Garden 22: 153-306.

Woodson, R.E. 1936. Studies in the Apocynaceae. IV. The American genera of Echitoideae. Annals of the Missouri Botanical Garden 23: 169-438.

Woodson, R.E. 1938a. (Asclepiadales) Apocynaceae. In: Barnhart, J.H. (ed.), North. American Fora 29: 179-185.

Woodson, R.E. 1938b. An evaluation of the genera Plumeria L. and Himatanthus Willd. Annals of the Missouri Botanical Garden 25: 189-224.

Woodson, R.E. 1951. Studies in the Apocynaceae. VIII. An interim revision of the genus Aspidosperma Mart. \& Zucc. Annals of the Missouri Botanical Garden 38: 119-206. 


\section{Apéndice 1}

\section{Índice de pliegos de herbario}

1. Allamanda cathartica L.

2. A. schottii Pohl

3. Allomarkgrafia plumeriiflora Woodson

4. Anechites nerium (Aubl.) Urban

5. Aspidosperma desmanthum Benth. ex Müll. Arg.

6. A. megalocarpon Müll. Arg.

7. Beaumontia grandiflora Wall.

8. Carissa macrocarpa (Eckl.) A. DC.

9. Cascabela gaumeri (Hemsl.) Lippold

10. C. ovata (Cav.) Lippold

11. C. thevetia (L.) Lippold

12. Catharanthus roseus (L.) G. Don.

13. Echites sp. A.

14. E. turbinatus Woodson

15. E. tuxtlensis Standl.

16. E. umbellatus Jacq.

17. E. woodsonianus Monach.

18. E. yucatanensis Millsp.

19. Fernaldia pandurata (A. DC.) Woodson

20. Forsteronia myriantha Donn. Sm.

21. F. spicata (Jacq.) G. Mey.

22. Lacmellea standleyi (Woodson) Monac

23. Macropharynx renteriae A.H. Gentry

24. Malouetia guatemalensis (Müll. Arg.) Standl.

25. Mandevilla acutiloba (A. DC.) Woodson

26. M. birsuta (Rich.) K. Schum.

27. M. subsagittata (Ruiz \& Pav.) Woodson

28. M. tubiflora (M. Martens \& Galeotti) Woodson

29. Mesechites trifidus (Jacq.) Müll. Arg.

30. Nerium oleander L.

31. Odontadenia macrantha (Roem. \& Schult.) Markgr.

32. O. puncticulosa (Rich.) Pulle

33. Pentalinon andrieuxii (Müll. Arg.) B.F. Hansen \& Wunderlin

34. P. luteum (L.) B.F. Hansen \& Wunderlin

35. Plumeria mariaelenae J. Gutiérrez \& J. Linares

36. P. obtusa L.

37. P. rubra L.

38. Prestonia longifolia (Sessé \& Moç.) J.F. Morales

39. P. mexicana A. DC.

40. P. portobellensis (Beurl.) Woodson

41. P. speciosa Donn. Sm.

42. Rauvolfia tetrapbylla L.

43. Rhabdadenia biflora (Jacq.) Müll. Arg.

44. Stemmadenia donnell-smithii (Rose) Woodson

45. S. eubracteata Woodson

46. S. pubescens Benth.

47. Tabernaemontana alba Mill.

48. T. amygdalifolia Jacq.

49. T. arborea Rose

50. T. divaricata (L.) R. Br. ex Roem. \& Schult.

51. Thenardia chiapensis J. Williams

52. Thevetia ahouai (L.) A. DC.

53. Tintinnabularia murallensis J. Williams

54. Tonduzia stenophylla (Donn. Sm.) Pittier

55. Vallesia aurantiaca (M. Martens \& Galeotti) J.F. Morales

Abraham, D., 148 (14).

Agudelo, N., 10 (45); 14 (13).

Aguilar, D., s.n. (19); 127 (24); 151 (46); 175 (46).

Allen, P., 6155 (46).

Alvarado, A., 153 (2).

Alvarado, F., 138 (1); 143 (49); 164 (14).

Alvarado, M., 164 (30); 178 (41).

Andino, R., 228 (45); 231 (33); 245 (36); 250 (47).
Andrieux, G., 245 (19); 247 (33); 251 (38).

Argeñal, F., 144 (43).

Argueta, L., 128 (46); 189 (46).

Banegas, A., 139 (2).

Barkley, F., 40878 (43).

Barkley, F. \& J. Hernández, 40274 (41); 40413 (36).

Bartlee, H., 12750 (5).

Belibasis, L., 6 (41).

Billberg, J., s.n. (39).

Blackmore, S. \& M. Chorley, 3693 (43); 3705 (46); 3754 (50); 3900 (36); 3910 (13); 4080 (17); 4143 (24).

Boghdan, K., 39432 (14).

Bonilla, C., 18 (27); 73 (41); 227 (14).

Botteri, M., 473 (54).

Brant, A. \& R. Zúñiga, 2818 (26).

Bueso, M., 42 (14).

Burch, D., 6029 (46).

Bustillo, B., 172 (16).

Cámbar, I., 113 (49); 147 (41); 156 (1).

Canizales, R., 2 (14).

Carleton, 424 (29).

Casco, C., 118 (14).

Castro, N., 99 (27); 1194 (49).

Cerna, C., 23 (30); 90 (1); 108 (46).

Cerrato, C., 95 (27).

Chorley, M., 186 (43).

Clare, T., 2 (1); 3 (16); 36 (41); 54 (49); 80 (16); 125 (49).

Clewell, A., 3079 (45); 3194 (46); 3632 (27); 4417 (46).

Clewell, A. \& G. Cruz, 4012 (50); 4030 (46); 4047 (1); 4125 (50).

Clewell, A. \& al., 3113 (43); 4307 (24); 4316 (46); 4329 (43); 4340 (24).

Colindres, O., 201 (46).

Croat, T., 45520 (40).

Croat, T. \& D. Hannon, 64067 (47); 64080 (41); 64145 (14); 64516 (41); 64556 (41).

Cruz, G., 101 (27); 226 (29); 256 (43); 554 (46).

Cruz, G. \& M. Espinal, 264 (34).

Cruz, R., 211 (50).

Daniel, T. \& J. Araque, 9506 (48).

D'Arcy, W., 18117 (52); 18144 (17).

D'Arcy, W. \& J. D'Arcy, 6866 (41).

Davidse, G., 34631 (46).

Davidse, G. \& al., 34458 (50); 34506 (38); 34977 (27); 35038 (21); 35249 (27); 35380 (27); 35449 (29); 35505 (41); 35510 (47).

Deam, C., 6098536376 (17).

Delgado, G., 10224106 (46).

Díaz, A., 90 (41).

Dickson, J., s.n. (29); 851 (42); 983 (48); 1604 (17); 1636 (45).

Dirección General de Biodiversidad SERNA 21 (43).

Doyle, C., 33 (53).

Dueñas, C., 100 (41).

Echeverría, M., 28 (30).

Edwards, J., 674 (46).

Eilers, L., 878 (13); 909 (17); 910 (45); 1038 (16).

Escobar, L., 24 (39).

Espinal, M., 67 (41).

Erazo, 65 (38).

Evans, R., 1022 (43); 1549 (47); 1604 (3); 1648 (22); 1649 (23); 1658 (22); 1670 (32); 1752 (52); 1753 (47).

Ferrera, A., 166 (36).

Friedrichsthal, 982 (24).

Fryxell, P., 2821 (42); 2837 (46).

Galeotti, H., 1591 (54); 1579 (28).

Gárces, C., 101 (30); 151 (30); 159 (16).

García, M., 38 (30); 40 (1).

Gaumer, G., 1979 (17).

Gentry, A. \& E. Renteria, 23955 (23).

Gentry, A. \& al., 7477 (46); 7516 (48); 7523 (31); 7457 (46); 7553 (42). 
Germer, L., 50 (1).

Giudicelli, M., 193 (1).

Glassman, S., 1596 (29); 1600 (41); 1819 (13); 1989 (28); 2194 (21).

Gordon, J., 155 (45); 193 (36); 209 (13); 212 (13).

Gordon, J. \& J. Sandoval, 202 (51); 203 (14).

Gorgún., 49 (49).

Guerra, I., 131 (24); 176 (14).

Guevara, R., 146 (14); 173 (16).

Hagen \& Hagen, 1120 (29).

Harmon \& J. Dwyer, 3470 (38); 3810 (43).

Hawkes, J. \& al. 2112 (28).

Hawkins, T., 144 (54); 503 (52).

Hawkins, T. \& D. Mejía, 503 (52).

Hawkins, T. \& M. Merello, 766 (48).

Hawkins, T. \& al., 836 (26).

Hayes, S., s.n. (19).

Haylock, J., 147 (30); 169 (46).

Hazlett, D., s.n. (7); 753 (46); 931 (13); 989 (45); 1194 (41); 1469 (48); 1489 (43); 1510 (31); 1696 (21); 1760 (13); 3114 (47).

Hazlett, D. \& Coe, 2743 (22).

Hazlett, D. et al., 8010 (48).

Hernández, J. \& J. Mancías, 1081 (46); 1122 (41); 1126 (41).

Hernández, M., 188 (50); 219 (50); 5181 (41).

Hernández, M. \& G. Rendón, 5392 (47); 5454 (46); 5467 (41).

Heyde, E. \& E. Lux, 3993 (28); 4497 (40); 4534 (20); 4540 (25).

Holst, B., 512 (7); 940 (47); 988 (13); 1029 (17); 1060 (45); 1065 (29); 1087 (36); $1129(21) ; 1363$ (44); 1793 (29).

Hinton, G., 15325 (7).

House, P., 1920 (46); 2080 (5).

House, P., \& A. Cubas, 2761 (48).

Izaguirre, E., 137 (41); 177 (14).

Johannessen, C., 395 (41); 527 (50); 723 (14); 947 (46).

Karwinski, W., 1348 (9).

Keyser, R., 1163 (15); 1411 (36).

Lainez, H., 28 (16).

Lawrence, A. \& al., 267 (46).

Leblond, M., s.n. (32); 387 (26).

Lentz, D., 439 (16); 472 (45); 587 (45); 845 (50); 1612 (50); 1719 (44).

Lezama, D., 124 (27).

Liesner, R., 26565 (52).

Liesner, R. \& D. Mejía 26373 (3).

Linares, J., 741 (50).

Linares, J. \& E. González, 7 (21).

Linares, J. \& J. Gutiérrez, 8501 (35).

Linares, J. \& R. Mesger, 1688 (17); 1711 (45); 1797 (28).

López, E., 225 (16).

Lundell, C. \& E. Contreras, 19461 (25).

Maas, P. \& al., 8462 (27).

MacDougal, J. \& al., 3355 (50); 3435 (42).

Mancías, J. \& J. Hernández, 1117 (50).

Marineros, L., 117 (16); 138 (1); 198 (49).

Martínez, E., 12759 (41).

Martínez, E. \& O. Téllez, 12754 (41); 13043 (27).

Martínez, H., 12 (29); 168 (43); 201 (45) 433 (29).

Martínez, I., 160 (16)

Martínez, J., 87 (16).

Matamoros, R., 25 (46).

Matuda, E., 2030 (5); 15570 (40); 16361 (5); 17386 (5).

McDougal, J. \& al., 3148 (50); 3296 (50).

McLaughlin, 7239 (28).

Méndez, O., 37 (45).

Mendoza, V., 58 (1).

Mejía, C., 62 (1).

Mejía, D., 452 (47).

Mejía, T., 8 (24); 9 (46); 206 (14).

Meyer, F., 9900 (1); (16).

Miegs, R., 1236 (46).

Molina, A., 118 (45); 151 (29); 188 (45); 224 (13); 373 (21); 386
(28); 485 (4); 870 (21); 930 (45); 1213 (38); 1572 (21); 2569 (38); 2781 (19); 3087 (29); 3211 (25); 3226 (45); 3254 (41); 3282 (30); 3344 (27); 3434 (43); 3483 (4); 3486 (43); 3489 (50); 3640 (19); 3751 (27); 3829 (29); 3880 (29); 4038 (13); 5208 (42); 5218 (46); 5219 (43); 5253 (46); 5316 (13); 5420 (13); 5469 (45); 5565 (39); 5575 (46); 5580 (26); 5629 (50); 5635 (41); 5760 (41); 5782 (28); 6203 (5); 6661a (41); 6664 (41); 6679 (50); 6680 (46); 6749 (41); 6749 a (46); 6756 (50); 6757 (48); 6764 (29); 6770 (41); 6806 (41); 6945 (46); 6951 (42); 6986 (17); 7012 (43); 7019 (21); 7199 (40); 7360 (46); 7363 (46); 7502 (41); 7511 (17); 8303 (41); 8335 (46); 8379 (46); 8411 (46); 8420 (17); 8425 (17); 10076 (17); 10082 (13); 10489 (26); 10565 (46); 10586 (26); 10768 (28); 10778 (41); 10966 (29); 10996 (7); 10997 (41); 11008 (13) 11012 (17); 11019 (28); 11380 (50); 11418 (46); 11465 (53); 11539 (26); 11582 (53); 11646 (41); 11797 (46); 13013 (43); 13103 (41); 13385 (46); 13770 (47); 13771 (41); 14224 (41); 14228 (17); 14310 (45); 14316 (17); 14538 (28); 14580 (30); 14629 (28); 14712 (1); 18423 (41); 18486 (28); 20648 (42); 20654 (18); 20676 (41); 20738 (46); 21941 (41); 21999 (46); 22000 (50); 22029 (45); 22051 (33); 22055 (17); 22423 (6); 22437 (13); 22464 (41); 22655 (28); 25912 (28); 25941 (14); 25969 (47); 25970 (45); 31705 (28); 33673 (16); 33913 (50); 33940 (36); 34043 (12); 34939 (36).

Molina, A. \& A. Molina, 22786 (33); 24595 (29); 24619 (41); 24650 (19); 24734 (27); 24793 (29); 25677 (46); 25882 (33); 27629 (28); 27958 (28); 31765 (28); 34435 (50); 34560 (49); 34941 (49); 34955 (50); 34993 (46); $35173(50)$.

Molina, A. \& al., 32099 (43); 32128 (41).

Molina, D., 169 (30).

Molina, J., 2 (50)

Montoya, A., s.n. (41)

Montoya, D., 44 (46).

Montoya, I., 167 (16); 188 (30).

Muñoz, S., 42 (41).

Murry, R., 434 (16); 459 (46).

Nelson, C., 136 (50); 188 (50); 230 (41); 793 (26); 1011 (50); 1240 (24); 1395 (13); 2120 (41); $2128(50) ; 2827$ (50); 3457 (41);3838 (27); 4364 (50); 4521 (50); 4840 (49); 4979 (46); 5049 (46);5050 (46); 5549 (46); 6120 (46); 6269 (46); 6761 (46); 6762 (46); 7757 (39); 7767 (46); 7775 (24); 7854 (42); 8311 (34); 8312 (34); 8358 (18); 8367 (50); 8495 (46); 8503 (42); 8551 (24); 8609 (12); 8822 (50); 8834 (50); 9139 (46); 9978 (16); 10543 (1); 11210 (46); 11266 (24); 11328 (29); 11385 (16); 11823 (1); 12532 (45); 14941 (50); 14942 (50); 15070 (46); 15663 (46); 16940 (12); 17399 (43); 18131 (48); 18134 (46); 20702 (50).

Nelson, C. \& N. Agudelo, 3832 (24).

Nelson, C. \& R. Andino, 10825 (50); 12645 (45); 12763 (29); 13083 (53); 13712 (36); 13713 (36); 15523 (29); 15942 (37); 16794 (43); 17099 (49); 18012 (50); 18036 (48); 18140 (46).

Nelson, C. \& V. Calera, 19551 (41).

Nelson, C. \& G. Cruz, 8709 (14); 8742 (27); 9027 (50); 9148 (29); 9164 (29); 9194 (31); 9481 (46).

Nelson, C. \& J. Escobar, 8596 (20).

Nelson, C. \& J. Hernández, 136 (50).

Nelson, C. \& M. Hernández, 967 (26); 968 (42); 1016 (1).

Nelson, C. \& H. Martínez, 7747 (41); 7749 (45).

Nelson, C. \& J. Martínez, 1154 (42); 1158 (46); 1947 (27); 1963 (43).

Nelson, C. \& E. Romero, 4174 (31); 4197 (50); 4245 (42); 4379 (46); 4617 (27).

Nelson, C. \& E. Vargas, 4934 (31).

Nelson, C. \& al., 304 (14); 1668 (19); 1693 (41); 2829 (46); 2868 (46); 2896 (1); 2957 (14); 3087 (50); 3203 (43); 4180 (26); 5031 (26); 5607 (27); 5801 (33); 6230 (19); 6416 (29); 6445 (29); 6446 (29); 6506 (41); 6595 (41); 6616 (40); 6915 (29); 6929 (29); 6936 (36); 7048 (41); 7211 (41); 7292 (40); 7619 (41); 7634 (41); 7648 (9); 8113 (43); 8591 (26); 9716 (34); 9719 (18); 97273510236 (41); 21095 (41).

Nelson, E., 3080 (6). 
Ochoa, V., 1241127 (16).

Ortega, A., 226 (41); 230 (1); 235 (50); 261 (43); 349 (46).

Ortiz, R., 418 (33).

Owen, P., 1 (39).

Padilla, F., 13 (41).

Padilla, I., 24 (30); 203 (14).

Palacios, M., 390 (41); 397 (46); 512 (47).

Pastor, N., 801 (30); 819 (30); 849 (14); 852 (16); 1017 (46); 1024 $(50) ; 1043(50) ; 1099(30)$

Pavón, H., s.n., (25).

Peck, M., 35 (27); 953 (37).

Peña., B., 176 (41).

Peña., B., 178 (45).

Pérez, T., s.n. (11).

Pineda, D., 154 (14)

Pineda, I., 37 (39).

Pineda, V., 148 (30).

Pipoly, J. et al., 24260 (26).

Portillo, R., 238 (16).

Proctor, G., 38957 (46).

Purpus, C., 7274 (25).

Quintana, P., 66 (41)

Ramos, O., 4 (30); 60 (16); 328 (30).

Ramos, R., 187 (24).

Renson, C., 289 (53).

Repulski, E., 74-62 (45); 322 (45); 396 (47); 436 (13).

Roden, J., 853 (27).

Romero, E., 45 (30); 57 (41).

Ruiz, H. \& H. Pavón, 11/56 (27).

Sagastume, D., 72 (16); 74 (49); 75 (30).

Sánchez, J., 122 (47); 186 (1).

Saunders, J., 253 (24); 293 (24); 303 (46); 306 (43); 307 (24); 396 (27); 400 (1); 432 (24); 448 (29); 461 (46); 462 (1); 600 (39); 619a (42); 771 (16); 876 (29); 1042 (1); 1082 (31).

Saunders, J. \& al., 624 (32); \& al., 854 (42).

Schipp, W., S-7 (38); S-388 (39); S-709 32

Schott, A., 5379 (2).

Segovia, J., 74 (46); 211 (16)

Serrano, M., 21 (29)

Sessé, M. \& J. Mociño, 5007 (37).

Sieber, s.n. (31)

Sierra, M., 68 (1).

Sosa, E., 161 (46)

Soto, C., 359 (50); 408 (24); 423 (16); 516 (29); 639 (1); 832 (1).

Soto, C. \& M. Espinal, 283 (46).

Standley, P., 5316 (45); 11594 (21); 12200 (4); 12412 (51); 12591 (19); 13139 (19); 14200 (41); 14573 (21); 15847 (13); 15939 (16); 16222 (29); 17518 (46); 17678 (51); 17682 (16); 17949 (13); 17959 (41); 18141 (21); 18185 (46); 18186 (41); 18374 (41); 18378 (49); 18402 (43); 20524 (13); 20858 (45); 20895 (38); 21277 (21); 21542 (36); 21610 (21); 21729 (45); 21955 (16); 22313 (1); 22540 (16); 22653 (49); 22684 (19); 22394 (19); 23300 (30); 23303 (1); 24491 (13); 24497 (41); 24896 (14); 25869 (45); 26257 (19); 26364 (21); 26441 (21); 26278 (19); 26475 (25); 26755 (14); 26903 (19); 26921 (19); 27012 (45); 27079 (19); 27137 (14); 27139 (21); 27159 (41); 28130 (19); 28478 (36); 29075 (29): 53619 (29); 54338 (31); 56470 (27); 72587 (22).

Standley, P. \& J. Chacón, 5244 (47); 5676 (14); 7246 (48).

Standley, P. \& H. Lindelie, 7327 (46).

Standley, P \& Padilla, 1926 (29).

Steyermark, J., 47313 (53).

Thieme, C., 5346 (27); 5347 (27).

Tonduz, A., 2147 (5).

Torres, J., 33 (46); 145 (46).

Tróchez, L., 51 (41).

Tuerckheim, H., 8709 (28).

Valerio, J., 64 (46); 65 (19); 230 (41); 362 (13); 369 (19); 515 (45); 858 (28); 877 (41); 944 (19); 964 (28); 1087 (1); 1120 (16); 1241 (41); 1593 (29); 2215 (14); 2216 (30); 2222 (16); 2230 (36); 2260
(49); 2320 (41); 2343 (47); 2367 (45);2399 (41);2512 (14);2609 (45); 2611 (36); 3244 (14); 3343 (33); 3353 (41); 3403 (45).

Valladares, 1 (28).

Valle, J., 3 (41).

Vallecillo, 46 (28).

Varela, R., 351 (47).

Vargas, E., 82 (46); 198 (45); 318 (46).

Vargas, E. \& al., 375 (24).

Villatoro, S., 2305 (30).

Villeda, M., s.n. (36); 94 (36); 130 (36); 261 (50)

Villena, L., 143 (41).

Webster, G. et al., 11997 (27); 12669 (46).

Williams, L., 12315 (45); 12484 (46); 12578 (45); 13247 (45); 14070 (41); 17158 (49); 17855 (46); 18001 (46); 18992 (45).

Williams, L. \& A. Molina, 10123 (27); 10205 (13); 10323 (28); 10525 (28); 10815 (27); 12428 (41); 12440 (48); 12470 (41); 12594 (13); 12609 (17); 13266 (41); 13385 (41); 14081 (45); 14630 (43); 14680 (41); 17856 (50); 18795 (41).

Williams, L. \& R. Williams, 18280 (45); 18330 (41); 18465a (29).

Wilson, P., 244 (42).

Yuncker, T., 4680 (46); 4818 (16).

Yuncker, T. et al., 5548 (27); 6049 (25); 8023 (47); 8078 (41); 8205 (43); 8222 (29); 8284 (50); 8593 (24); 8613 (36); 8655 (41); 8672 (24); $8696(24)$.

Zelaya, L., 230 (41).

Zúñiga, R., 5 (41); 919 (46).

\section{Apéndice 2}

\section{Índice de nombres comunes}

Adelfo (30). Alcotán (42). Allamanda (1). Amatillo (42). Amor de hombre (42). Astro de Italia (30). Barquillo (46). Barquito (24). Bejuco de culebra (26). Bejuco de San José (1). Buksa mahbra (43, 46, 48). Buksa makalaya (51). Buntun (24). Cacalichuche (36). Cacalochucho (36). Cachito (49). Cacho de cabra (40). Calachuche (36). Calichuche (36). Candelero (36). Cañamito (5). Chalchuapa (42). Chanchito (47). Chapel (9). Chaperno (9). Chapupo (47). Chila (11). Chilca $(44,51)$. Chilco (11). Chilindrón $(13,14,15,47$, 51). Chirca (10). Chivo $(45,48)$. Cuchampercitos (19). Chula (12). Chuladita (12). Chulita (12). Ciruela de Natal (12). Clavellina (12). Codo de fraile $(52)$. Codo de monje $(15,51)$. Cojón $(45,46)$. Cojón de burro $(24,43,46,47,48)$. Cojón de caballo (49). Cojón de gato (47). Cojón de Mico (24, 43, 46, 47). Cojón de Potro (43, 48). Cojón de Puerco (46). Comida de culebra (42). Copa de Oro (1). Coronaria (49). Corrimiento (29). Esquijoche (36). Falsa gardenia (49). Flor de la cruz (36). Flor de Mayo (36). Flor de mico (27). Flor mestiza (36). Fragipani (36). Fruta de culebra (42). Fustán de vieja (9). Hombre grande (42). Huele de Noche (24). Huevo de burro (52). Huevo de caballo (44). Huevo de gato (52). Huevo de Mono (47). Huevo de toro $(43,48,49)$. Huevos de burro (44). Huevos de chancho $(43,45,46)$. Joche (36). Juche (36). Káuput (31). Laurel (30). Laurel rosa (30). Leche de Burro (42). Lechera (48). Lechón (24). Lechón Negro (24). Lechoso (52). Loroco (19, 39). Magnolia (49). Mamba (tawahka) (5). Manzana de perro (52). Mariposa (12). Matacoyote (42). Matiar (42). Muku (tawahka) (49). Mulata (12). Mulatillo (12). Narciso (30). Oajaca (12). Oaxaca (12). Oleander (30). Oloroco (19). Oreja de Chancho (12). Orejuel (12). Palo de la cruz (36). Palo de vaca (22). Paloni berry (52). Pervinca (12). Primorosa (12). Primorosa morada (12). Quiebramuela $(43,48,51)$. Quiebramuelas $(14,15,45)$. Ramgoat (12). Rosal de la mar del sur (30). Sacalinchuche (36). Sacuanjoche (36). Señorita $(16,41)$. Tomatillo (42). Tomatillo de árbol (42). Trompeta de heraldo (7). Viborilla (42). Yampus (mískito) (5). Young girl's booby (49).

Editor asociado: C. Ulloa Recibido: 22-VIII-2008 Aceptado: 25-V-2009 